\title{
Copper Dithiocarbamates: Coordination Chemistry and Applications in Materials Science, Biosciences and Beyond
}

\author{
Graeme Hogarth ${ }^{1, *(D)}$ and Damian C. Onwudiwe ${ }^{2, *(D)}$ \\ 1 Department of Chemistry, King's College London, Britannia House, 7 Trinity Street, London SE1 1DB, UK \\ 2 Department of Chemistry, Faculty of Natural and Agricultural Science, North-West University, Mafikeng \\ Campus, Private Bag X2046, Mmabatho 2735, South Africa \\ * Correspondence: graeme.hogarth@kcl.ac.uk (G.H.); Damian.Onwudiwe@nwu.ac.za (D.C.O.)
}

Citation: Hogarth, G.; Onwudiwe, D.C. Copper Dithiocarbamates: Coordination Chemistry and Applications in Materials Science, Biosciences and Beyond. Inorganics 2021, 9, 70. https://doi.org/10.3390/ inorganics 9090070

Academic Editor: Duncan H. Gregory

Received: 4 August 2021

Accepted: 23 August 2021

Published: 10 September 2021

Publisher's Note: MDPI stays neutral with regard to jurisdictional claims in published maps and institutional affiliations.

Copyright: () 2021 by the authors. Licensee MDPI, Basel, Switzerland. This article is an open access article distributed under the terms and conditions of the Creative Commons Attribution (CC BY) license (https:// creativecommons.org/licenses/by/ $4.0 /)$.

\begin{abstract}
Copper dithiocarbamate complexes have been known for ca. 120 years and find relevance in biology and medicine, especially as anticancer agents and applications in materials science as a single-source precursor (SSPs) to nanoscale copper sulfides. Dithiocarbamates support $\mathrm{Cu}(\mathrm{I}), \mathrm{Cu}$ (II) and $\mathrm{Cu}(\mathrm{III})$ and show a rich and diverse coordination chemistry. Homoleptic $\left[\mathrm{Cu}\left(\mathrm{S}_{2} \mathrm{CNR}_{2}\right)_{2}\right]$ are most common, being known for hundreds of substituents. All contain a $\mathrm{Cu}$ (II) centre, being either monomeric (distorted square planar) or dimeric (distorted trigonal bipyramidal) in the solid state, the latter being held together by intermolecular C $\cdots S$ interactions. Their $\mathrm{d}^{9}$ electronic configuration renders them paramagnetic and thus readily detected by electron paramagnetic resonance (EPR) spectroscopy. Reaction with a range of oxidants affords $\mathrm{d}^{8} \mathrm{Cu}(\mathrm{III})$ complexes, $\left[\mathrm{Cu}\left(\mathrm{S}_{2} \mathrm{CNR}_{2}\right)_{2}\right][\mathrm{X}]$, in which copper remains in a square-planar geometry, but $\mathrm{Cu}-\mathrm{S}$ bonds shorten by ca. $0.1 \AA$. These show a wide range of different structural motifs in the solid-state, varying with changes in anion and dithiocarbamate substituents. $\mathrm{Cu}(\mathrm{I})$ complexes, $\left[\mathrm{Cu}\left(\mathrm{S}_{2} \mathrm{CNR}_{2}\right)_{2}\right]^{-}$, are (briefly) accessible in an electrochemical cell, and the only stable example is recently reported $\left[\mathrm{Cu}\left(\mathrm{S}_{2} \mathrm{CNH}_{2}\right)_{2}\right]\left[\mathrm{NH}_{4}\right] \cdot \mathrm{H}_{2} \mathrm{O}$. Others readily lose a dithiocarbamate and the $\mathrm{d}^{10}$ centres can either be trapped with other coordinating ligands, especially phosphines, or form clusters with tetrahedral $\left[\mathrm{Cu}\left(\mu_{3}-\mathrm{S}_{2} \mathrm{CNR}_{2}\right)\right]_{4}$ being most common. Over the past decade, a wide range of $\mathrm{Cu}(\mathrm{I})$ dithiocarbamate clusters have been prepared and structurally characterised with nuclearities of 3-28, especially exciting being those with interstitial hydride and/or acetylide co-ligands. A range of mixed-valence $\mathrm{Cu}(\mathrm{I})-\mathrm{Cu}(\mathrm{II})$ and $\mathrm{Cu}(\mathrm{II})-\mathrm{Cu}(\mathrm{III})$ complexes are known, many of which show novel physical properties, and one $\mathrm{Cu}(\mathrm{I})-\mathrm{Cu}(\mathrm{II})-\mathrm{Cu}(\mathrm{III})$ species has been reported. Copper dithiocarbamates have been widely used as SSPs to nanoscale copper sulfides, allowing control over the phase, particle size and morphology of nanomaterials, and thus giving access to materials with tuneable physical properties. The identification of copper in a range of neurological diseases and the use of disulfiram as a drug for over 50 years makes understanding of the biological formation and action of $\left[\mathrm{Cu}\left(\mathrm{S}_{2} \mathrm{CNEt}_{2}\right)_{2}\right]$ especially important. Furthermore, the finding that it and related $\mathrm{Cu}$ (II) dithiocarbamates are active anticancer agents has pushed them to the fore in studies of metal-based biomedicines.
\end{abstract}

Keywords: copper; dithiocarbamate; clusters; nanomaterials; disulfiram; anticancer agents

\section{Introduction}

Copper is an intriguing element with interesting and useful properties and has been widely used by mankind for ca. 6000 years. It is relatively abundant in the earth's crust (50-60 ppm), being found in both its elemental form and in a range of minerals. Especially pertinent to this review, it is found in a range of copper sulfides including chalcopyrite, digenite, covellite and chalcocite [1]. Copper is an essential element for all living organisms, being a key constituent of the active site of respiratory enzymes cytochrome c oxidases, and a human contains 1.4-2.1 mg of copper per kg of body mass. Balancing copper levels in the body is extremely important, and recently major changes in copper concentrations and its 
localisation have been identified with Alzheimer's disease [2]. Copper has an extensive and rich coordination chemistry, forming complexes in oxidation states from 0 to +4 , with the +2 (cupric) state being by far the most prevalent, although +1 (cuprous) complexes are also abundant. Its complexes find extensive applications, for example as catalysts, fungicides and pesticides, pigments and solid-state materials with novel physical properties such as high-temperature superconductors.

Dithiocarbamates are an important class of monoanionic dithiolate ligands. Easily prepared from a wide range on secondary and primary amines, they coordinate to most of the elements in the periodic table, including all the transition elements $[3,4]$. Copper forms dithiocarbamate complexes in three oxidation states, $+1,+2$ and +3 , the most common being four-coordinate $\mathrm{Cu}(\mathrm{II})$ bis(dithiocarbamates), $\left[\mathrm{Cu}\left(\mathrm{S}_{2} \mathrm{CNR}_{2}\right)_{2}\right]$, first documented by Delépine at the beginning of the 20th century [5,6]. Over the past $100+$ years, interest in copper dithiocarbamate complexes has developed enormously, for example a SciFinder@ search for $\left[\mathrm{Cu}\left(\mathrm{S}_{2} \mathrm{CNEt}_{2}\right)_{2}\right]$ alone gives ca. 900 hits with applications in areas as diverse as medicine, materials science, agriculture, biochemistry, catalysis and water purification. In this review, we give an overview of the coordination chemistry of copper dithiocarbamates, together with recent developments of their applications, especially towards the synthesis of nanoscale metal sulfides and in biological systems, for example as anti-cancer agents.

\section{Copper(II) Bis(dithiocarbamate) Complexes}

When Delépine first combined aqueous solutions of $\mathrm{NaS}_{2} \mathrm{CN}^{\mathrm{i}} \mathrm{Bu}_{2}$ and various $\mathrm{Cu}$ (II) salts around 1907-8, he would have observed the immediate and high yielding formation of a dark brown precipitate of the bis(dithiocarbamate) complex, $\left[\mathrm{Cu}\left(\mathrm{S}_{2} \mathrm{CN}^{\mathrm{i}} \mathrm{Bu}_{2}\right)_{2}\right]$ $[5,6]$. This simple reaction works for an astounding variety of secondary amine-derived dithiocarbamate salts. Work up is normally straightforward, involving simple separation by filtration and drying in a standard lab oven $[7,8]$. Binding constants are of the order $10^{7}-10^{8}$ for simple dialkylamines (in ethanol with $\mathrm{CuCl}_{2}$ ) [8] and this has led dithiocarbamates to be developed as reagents capable of removing copper to very low levels in water $[9,10]$, and from pharmaceutical processes where copper has been used as a catalyst [11]. Oxidative addition of thiuram disulfides to copper metal is an alternative synthetic route, giving good yields [12,13].

A wide range of $\mathrm{Cu}$ (II) bis(dithiocarbamate) complexes have been reported (Figure 1). They fall into three main types. Most common are dialkyl complexes, which can be symmetrically or unsymmetrically substituted or encompassed into a cyclic system, and a large number of these have been prepared [7,8,14-21]. Over the past decade, an increasing number of alkyl-aryl complexes (Figure 1d) have been documented, also being prepared by the same simple method as described above [22-24]. Until recently, diaryl-substituted $\left[\mathrm{Cu}\left(\mathrm{S}_{2} \mathrm{CNAr}_{2}\right)_{2}\right]$ (Figure 1e) were not well-documented, but they can be made in a similar way starting from the lithium dithiocarbamate salts [25]. Complexes from primary amines, $\left[\mathrm{Cu}\left(\mathrm{S}_{2} \mathrm{CNHR}\right)_{2}\right]$, appear not to be stable, and as far as we are aware, none have been fully characterised [26-29].<smiles></smiles>

(a)

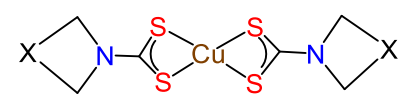

(b)

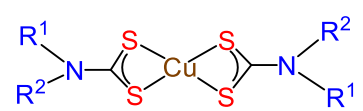

(c)

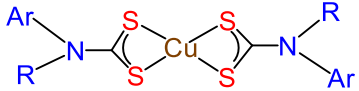

(d)

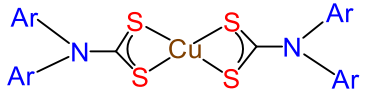

(e)

Figure 1. Examples of common $\mathrm{Cu}(\mathrm{II})$ bis(dithiocarbamate) motifs (a-e).

Many variants have been prepared, examples of which are shown in Figure 2. The addition of substituents to the end of alkyl chains (Figure 2a) allows tuning of the water solubility (e.g., $\mathrm{X}=\mathrm{OH}$ ) $[16,30,31]$ and acid-base properties (e.g., $\mathrm{X}=\mathrm{CO}_{2} \mathrm{H}$ or $\mathrm{NEt}_{2}$ ) $[30,31]$. 
Beer and co-workers have synthesised a series of macrocyclic complexes containing two (Figure $2 \mathrm{~b}$ ) or three $\mathrm{Cu}(\mathrm{II})$ bis(dithiocarbamate) centres [32-34], some of which serve as selective anion receptors [32,33]. Due to the lability of the dithiocarbamate ligands (see later), complexes with two different dithiocarbamates will be in equilibrium with the homoleptic species. However, by binding a piperazine onto a gold surface through a thiol linkage, Cao and co-workers have anchored the unsymmetrical copper centre (Figure 2c) to a gold surface [35]. Recently, Omondi and co-workers have extended the number of aryl-alkyl complexes, preparing a small library (Figure 2d) in which the alkyl group has an imine linkage, which can potentially be further derivatised. The complex shown in Figure 2e is representative of those prepared by Fregona and co-workers to probe their anti-cancer activity, with water (ideally or DMSO) solubility being a pre-requisite $[36,37]$. Appending a crown ether ring onto the backbone (Figure 2f) allows the redox-active $\mathrm{Cu}(\mathrm{II})$ centre to act as a sensor for cation binding [26]. Blower and co-workers have prepared bis(phosphonate) derivatives (Figure 2f), incorporating ${ }^{64} \mathrm{Cu}$ for imaging applications [38] and Wilton-Ely has linked together ruthenium (Figure $2 \mathrm{~h}$ ) and other metal centres through a $\mathrm{Cu}(\mathrm{II})$ dithiocarbamate motif [39].

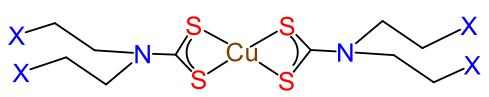

(a)

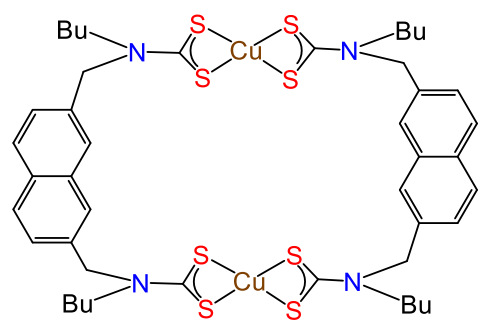

(b)

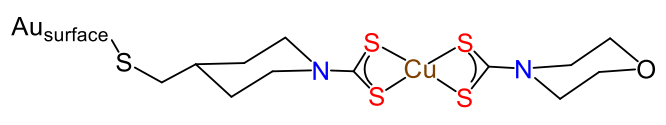

(c)

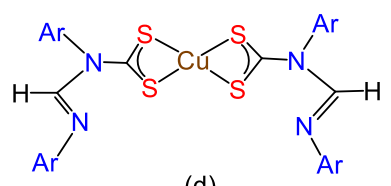

(d)<smiles>CC(C)COC(=O)C1CCCN1C1=S2S3=C(N4CCCC4C(=O)OCC(C)C)SC23S1</smiles><smiles>C1COCCOCCOCCN(C2=S3SC4(S2)SC3S4)CCOCCOCCOCCO1</smiles>

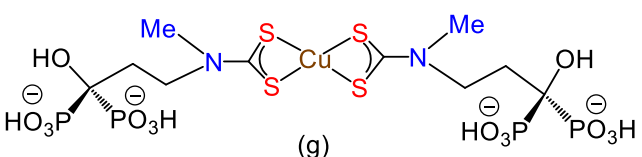

(g)

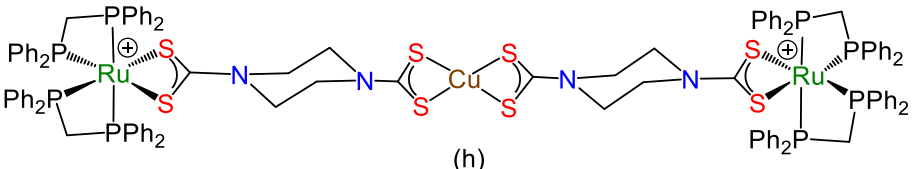

(h)

Figure 2. Examples of novel $\mathrm{Cu}(\mathrm{II})$ bis(dithiocarbamate) complexes (a-h).

There are reports of $\mathrm{Cu}$ (II) complexes containing two different dithiocarbamates [40,41], but no well-characterised examples, and due to the lability of the dithiocarbamate at the $\mathrm{Cu}$ (II) centre, it seems likely these are mixtures with the homoleptic dithiocarbamate complexes (see later). Thus a literature report of $\left[\mathrm{Cu}\left(\mathrm{S}_{2} \mathrm{CNMe}_{2}\right)\left(\mathrm{S}_{2} \mathrm{CNEt}_{2}\right)\right]$, formed upon the addition of tetramethyl thiuram disulfide to the $\mathrm{Cu}(\mathrm{I})$ cluster, $\left[\mathrm{Cu}\left(\mu_{3}-\mathrm{S}_{2} \mathrm{CNEt}_{2}\right)\right]_{4}[40]$, is likely a mixture with $\left[\mathrm{Cu}\left(\mathrm{S}_{2} \mathrm{CNMe}_{2}\right)_{2}\right]$ and $\left[\mathrm{Cu}\left(\mathrm{S}_{2} \mathrm{CNEt}_{2}\right)_{2}\right]$. In contrast, isomeric $\left[\mathrm{Cu}\left(\mathrm{S}_{2} \mathrm{CNMeEt}\right)_{2}\right]$ is wellcharacterised [42].

Almost a century passed between the initial synthesis of $\left[\mathrm{Cu}\left(\mathrm{S}_{2} \mathrm{CN}^{i} \mathrm{Bu}_{2}\right)_{2}\right]$ and the elucidation of its structure by single-crystal X-ray diffraction (Figure 3a) [7]. As in all $\mathrm{Cu}$ (II) dithiocarbamate complexes, a square-planar structure is adopted and many, like $\left[\mathrm{Cu}\left(\mathrm{S}_{2} \mathrm{CN}^{\mathrm{i}} \mathrm{Bu}_{2}\right)_{2}\right]$, are centrosymmetric in the solid-state, with $\mathrm{Cu}-\mathrm{S}$ bond lengths [2.268(1) and 2.302(1) $\AA$ ] and a S-Cu-S bond angle $\left[77.6(1)^{\circ}\right]$ being typical. In the gas phase, 
the monomeric structure is maintained as shown by an electron diffraction study of $\left[\mathrm{Cu}\left(\mathrm{S}_{2} \mathrm{CNMe}_{2}\right)_{2}\right]$ [43]. In the solid state, the latter adopts an unusual polymeric structure in which four-coordinate subunits are linked via long-range intermolecular $\mathrm{Cu} \cdots \mathrm{S}$ interactions, with each copper centre being pseudo-octahedral [44]. This arrangement appears to be unique to the dimethyl-derivative, and all other solid-state structures (broadly) fall into two types, isolated monomers and weakly bound dimers $[3,7,8,14,16,21,30,45-47]$. In the latter, the secondary intermolecular $\mathrm{Cu} \cdots \mathrm{S}$ interactions are of the order ca. 2.7$2.9 \AA$ and this brings the two copper centres within ca. 3.4-3.8 $\AA$, as highlighted by the solid-state structure of $\left[\mathrm{Cu}\left(\mathrm{S}_{2} \mathrm{CNBu}_{2}\right)_{2}\right]$ (Figure 3b) [7]. In dimers, the copper centre is five-coordinate and the $\mathrm{CuS}_{4}$ moiety is significantly deviated from planarity, suggesting that it contains quite soft $\mathrm{Cu}-\mathrm{S}$ interactions as supported by theoretical calculations [48]. As recently discussed and illustrated by Tiekink [49], secondary $\mathrm{C}-\mathrm{H} \cdots \pi$ (chelate ring) interactions are common in the solid-state structures of copper (and structurally similar nickel) dithiocarbamate complexes. Thus, 28 of 59 crystal structures of $\left[\mathrm{Cu}\left(\mathrm{S}_{2} \mathrm{CNR}_{2}\right)_{2}\right]$ in the Cambridge Crystallographic Data Base have $\mathrm{C}-\mathrm{H} \cdots \pi$ (chelate) interactions with individual units tending to self-associate into one- or two-dimensional architectures.

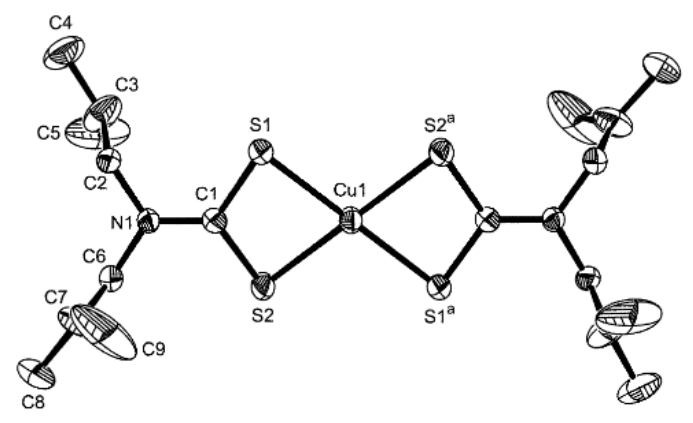

(a)

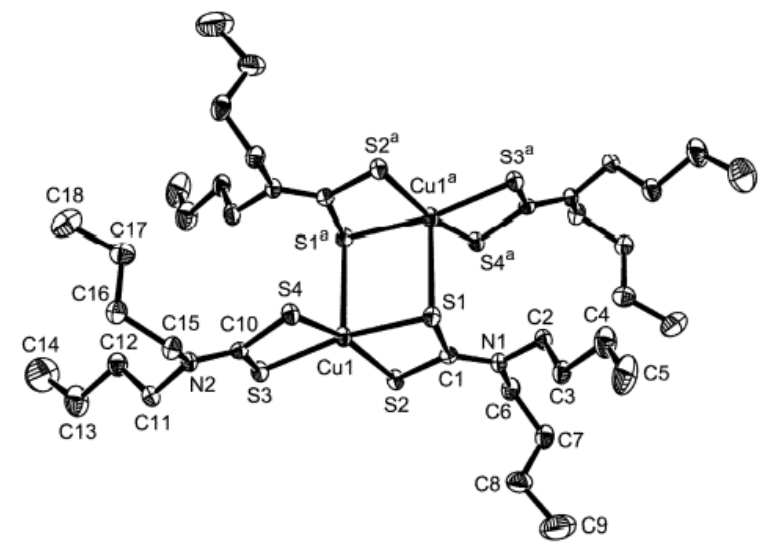

(b)

Figure 3. (a) Molecular structure of $\left[\mathrm{Cu}\left(\mathrm{S}_{2} \mathrm{CN}^{\mathrm{i}} \mathrm{Bu}_{2}\right)_{2}\right]$ as an example of a centrosymmetric monomeric complex, (b) molecular structure of $\left[\mathrm{Cu}\left(\mathrm{S}_{2} \mathrm{CN}^{\mathrm{i}} \mathrm{Bu}_{2}\right)_{2}\right]$ as an example of a dimeric complex in the solid state. Reproduced with permission from [7]. Copyright 2003 Elsevier.

Some structurally interesting solid-state structures have been generated that contain fullerenes and $\mathrm{Cu}(\mathrm{II})$ bis(dithiocarbamates). In the first approach, Konarev and co-workers have shown that co-crystallisation of $\left[\mathrm{Cu}\left(\mathrm{S}_{2} \mathrm{CNEt}_{2}\right)_{2}\right]$ and $\mathrm{C}_{60}$ from benzene gives a layered structure (Figure 4) that shows some interesting physical properties [50]. Thus, while in the dark this solid has a conductivity of only $10-11 \mathrm{~S} \mathrm{~cm}^{-1}$, illumination by white light increases this by ca. 20-50 times. Further, the photoconductivity spectrum shows a maximum at $470 \mathrm{~nm}$, suggesting that both intermolecular charge transfer between neighbouring $\mathrm{C} 60$ molecules and photoexcitation of the $\mathrm{Cu}$ (II) centre contributes to the photogeneration of free charge carriers. Related clathrate structures are formed from C60 
and $\mathrm{C} 70$ with a range of $\left[\mathrm{Cu}\left(\mathrm{S}_{2} \mathrm{CNR}_{2}\right)_{2}\right]$ and the copper centres can be monomeric, dimeric or tetrameric $[50,51]$.

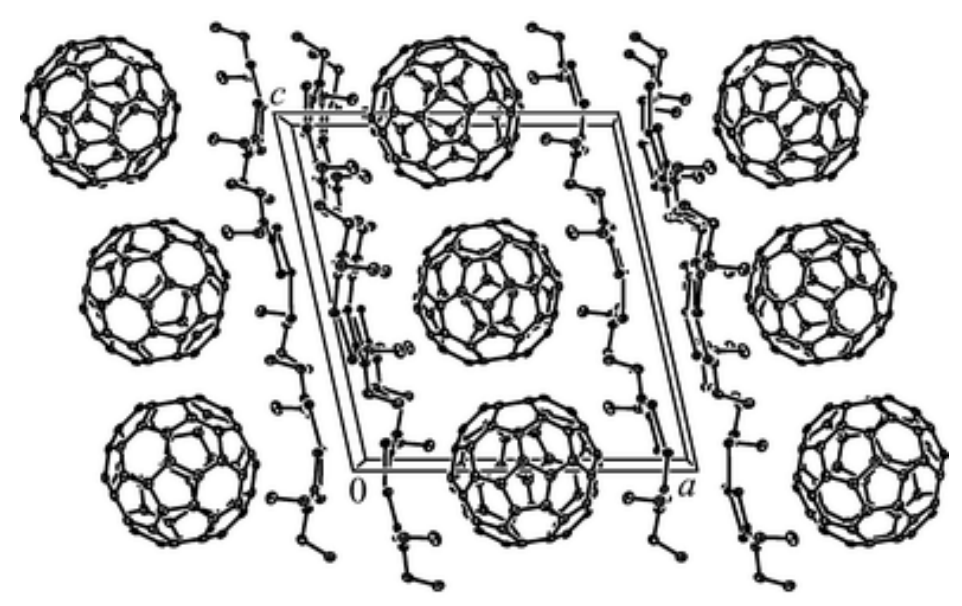

Figure 4. Molecular structure of $\left[\mathrm{Cu}\left(\mathrm{S}_{2} \mathrm{CNEt}_{2}\right)_{2}\right] \cdot \mathrm{C}_{60}$. Reproduced with permission from [50]. Copyright 2005 The Royal Society of Chemistry.

In a different approach, Beer and co-workers have prepared a range of nanosized polymetallic resorcinarene complexes, containing eight $\mathrm{Cu}$ (II) centres (Figure 5), the central cage of which is in the order of $0.4-0.7 \mathrm{~nm}$ in diameter [52]. While this cavity is large enough to include $\mathrm{C}_{60}$, access is blocked as the portals are too small to allow entry. Nevertheless, in organic solvents and the presence of $\mathrm{NOBF}_{4}$, slow incorporation of the fullerene into the cavity was shown by mass spectrometry. This is consistent with the reversible binding of the dithiocarbamate to the copper centre.

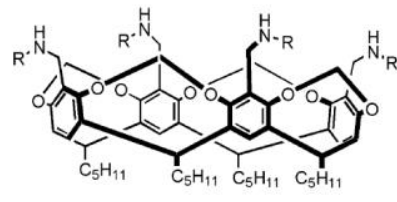

(2) $\mathrm{R}=n$-propyl

(3) $\mathrm{R}=n$-butyl

(4) $\mathrm{R}=n$-hexyl

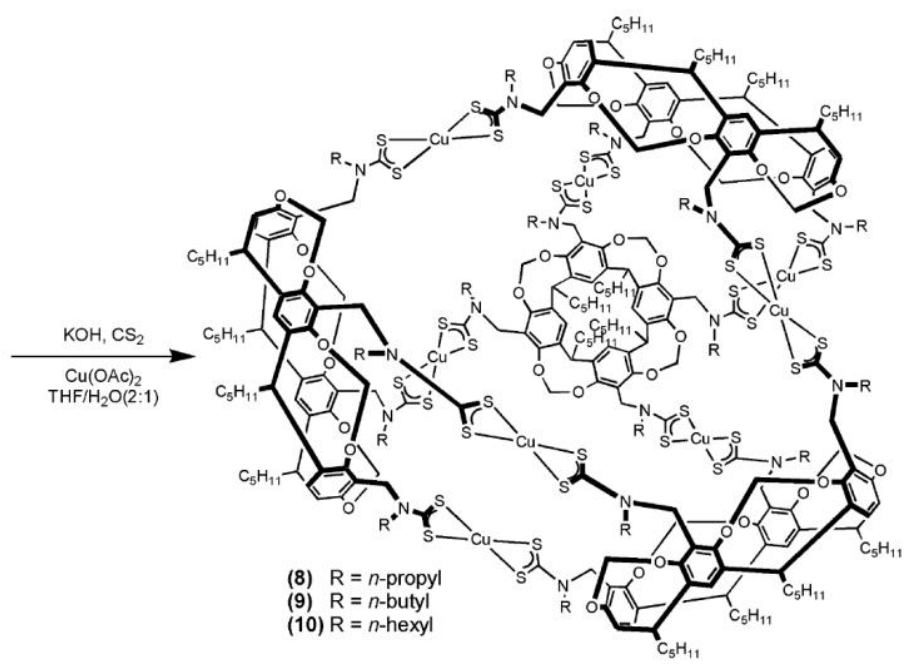

Figure 5. Formation of nanoscale resorcinarene complexes containing $\mathrm{Cu}(\mathrm{II})$ bis(dithiocarbamate) centres. Reproduced with permission from [52]. Copyright 2006 American Chemical Society.

As $\mathrm{d}^{9}$-centres, all $\mathrm{Cu}$ (II) bis(dithiocarbamate) complexes are paramagnetic, exhibiting magnetic susceptibilities of 1.6-1.9 BM, consistent with a single unpaired electron. The latter makes them amenable to study by EPR spectroscopy [53,54], with the spectrum of $\left[\mathrm{Cu}\left(\mathrm{S}_{2} \mathrm{CNEt}_{2}\right)_{2}\right]$ recorded in heptane being shown (Figure 6) [55]. Spectra are somewhat solvent dependent but vary a little in non-coordinating solvents. However, in coordinating solvents such as DMSO, large variation is observed suggesting the formation of an adduct [56]. The spectra are consistent with the delocalisation of the odd electron over the $\mathrm{CuS}_{4}$ moiety, which is supported by theoretical calculations [57]. The EPR signal is useful for probing the 
nature of dithiocarbamates in biological systems [58], especially the fate of the widely used alcohol-abuse drug disulfiram, $\left(\mathrm{Et}_{2} \mathrm{NCS}_{2}\right)_{2}$, as $\left[\mathrm{Cu}\left(\mathrm{S}_{2} \mathrm{CNEt}_{2}\right)_{2}\right]$ is readily formed following its reduction [59-62]. Given their paramagnetism, NMR spectra are not very informative. In some cases, resonances distant from the $\mathrm{Cu}$ (II) centre can be observed [36], but frustratingly the distinctive high-field resonance of the backbone carbon in the ${ }^{13} \mathrm{C}$ NMR spectrum cannot be observed. A second key feature of $\mathrm{Cu}$ (II) bis(dithiocarbamate) complexes is their brown coloration. This results from an intense absorption at ca. $435 \mathrm{~nm}\left(\varepsilon=13,000 \mathrm{dm}^{3} \mathrm{~mol}^{-1} \mathrm{~cm}^{-1}\right)$ for $\left[\mathrm{Cu}\left(\mathrm{S}_{2} \mathrm{CNEt}_{2}\right)_{2}\right]$ in $\mathrm{CCl}_{4}$, being attributed to a solvent-independent equatorial ligandmetal charge transfer, proving extremely useful for characterisation and also for following subsequent chemical transformations.

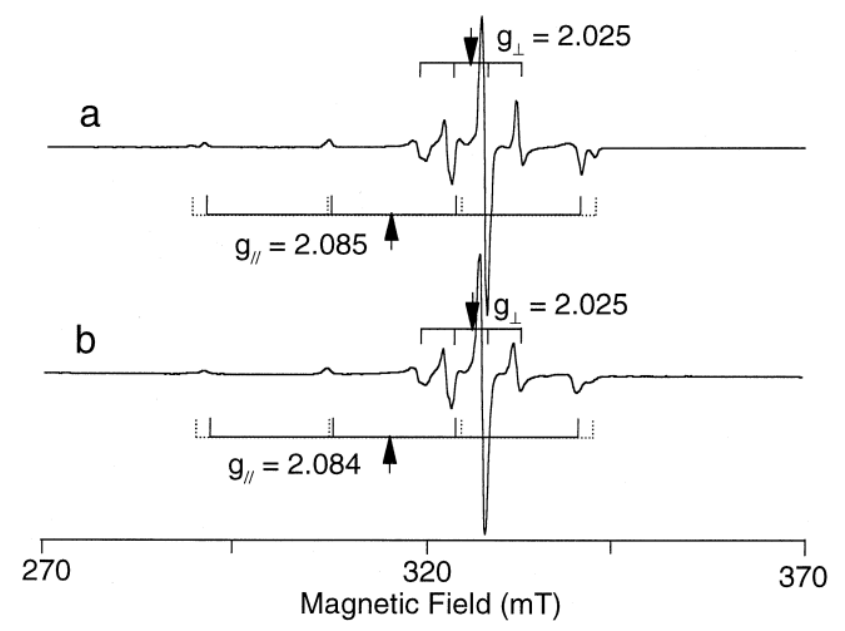

Figure 6. EPR spectrum of $\left[\mathrm{Cu}\left(\mathrm{S}_{2} \mathrm{CNEt}_{2}\right)_{2}\right]$ at $77 \mathrm{~K}$ in (a) $\mathrm{EtOH}(0.05 \mathrm{mM})$ and (b) albumin-containing aqueous solution. Reproduced with permission from [58]. Copyright 1996 Elsevier.

Their thermal stability has been extensively explored. Melting points are substituent dependent, $\left[\mathrm{Cu}\left(\mathrm{S}_{2} \mathrm{CNEt}_{2}\right)_{2}\right]$ melting at ca. $200{ }^{\circ} \mathrm{C}$ and (modest) increases in volatility are seen for longer alkyl-chain derivatives $[7,63,64]$. Most of them degrade at $230-300{ }^{\circ} \mathrm{C}$ to generate a range of copper sulfides, and this makes them excellent single-source precursors (SSPs) (as will be discussed later). Another key feature is their redox behaviour [65]. They undergo a fully reversible one-electron oxidation to give analogous $\mathrm{Cu}$ (III) complexes, $\left[\mathrm{Cu}\left(\mathrm{S}_{2} \mathrm{CNR}_{2}\right)_{2}\right]^{+}$, while reduction is a quasi-reversible one-electron process (Figure 7). Reduction generates $\mathrm{Cu}(\mathrm{I})$ species, $\left[\mathrm{Cu}\left(\mathrm{S}_{2} \mathrm{CNR}_{2}\right)_{2}\right]^{-}$, which as $\mathrm{d}^{10}$ complexes should undergo a structural rearrangement from square planar to tetrahedral, accounting for the quasireversibility. Attempts to isolate the reduced products lead to loss of a dithiocarbamate with the formation of $\mathrm{Cu}(\mathrm{I})$ clusters $\left[\mathrm{Cu}\left(\mathrm{S}_{2} \mathrm{CNR}_{2}\right)\right]_{n}$. Redox potentials vary significantly with the nature of the substituents. Thus, $\left[\mathrm{Cu}\left(\mathrm{S}_{2} \mathrm{CNCy}_{2}\right)_{2}\right]$ oxidises at $0.57 \mathrm{~V}$, while oxidation of $\left[\mathrm{Cu}\left(\mathrm{S}_{2} \mathrm{CNPh}_{2}\right)_{2}\right]$ occurs at $0.71 \mathrm{~V}$ [65]. Likewise, the latter reduces at $-0.26 \mathrm{~V}$, as compared to $-0.49 \mathrm{~V}$ for the dicyclohexyl complex. Interestingly, the resorcinarene complexes (Figure 5) prepared by Beer and co-workers show a single reversible oxidation process suggesting that all eight $\mathrm{Cu}(\mathrm{II})$ centres are oxidised in one step, a process that is unaffected by the inclusion of $\mathrm{C}_{60}$ [52]. 


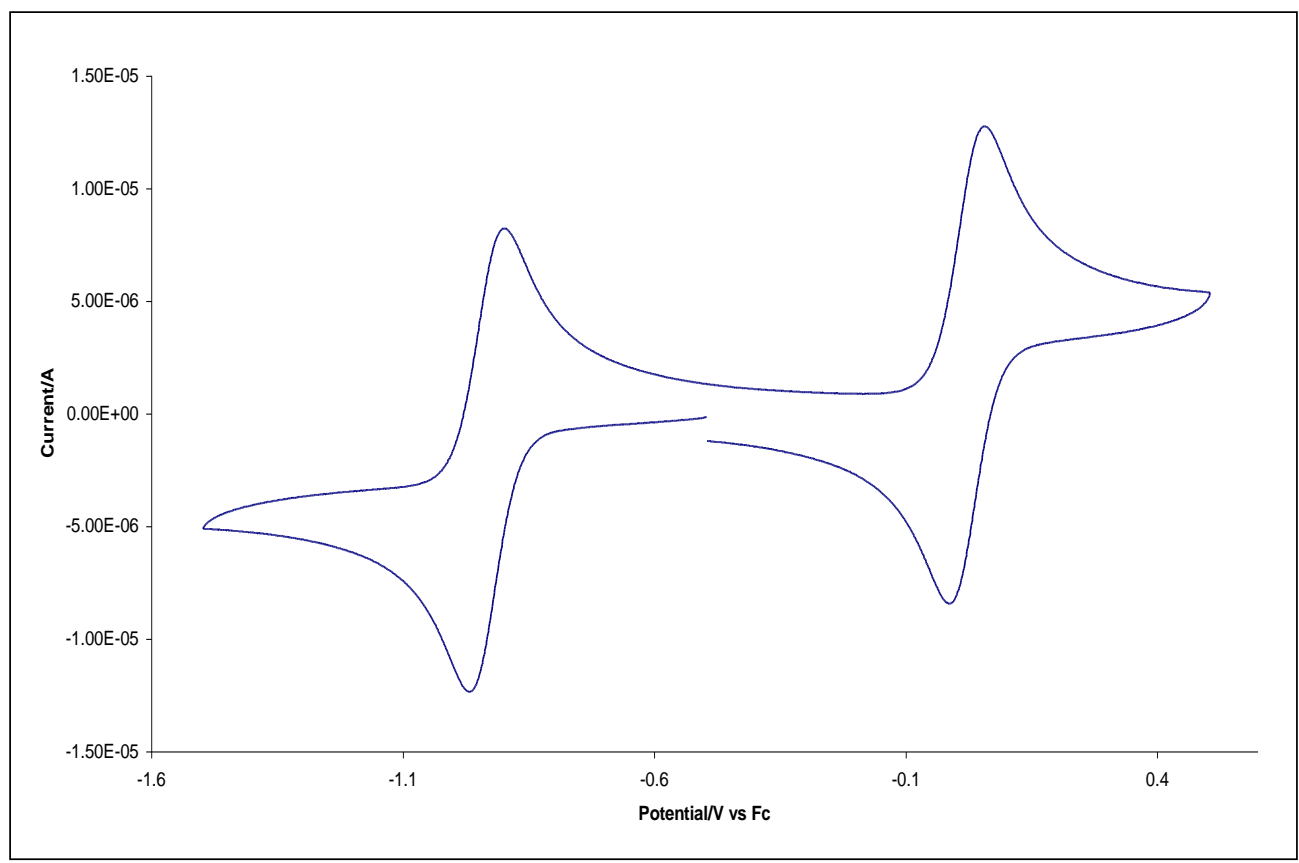

Figure 7. Cyclic voltammetry of $\left[\mathrm{Cu}\left(\mathrm{S}_{2} \mathrm{CN}^{\mathrm{i}} \mathrm{Bu}_{2}\right)_{2}\right]$ in $\mathrm{MeCN}$.

The reactivity of $\left[\mathrm{Cu}\left(\mathrm{S}_{2} \mathrm{CNR}_{2}\right)_{2}\right]$ has been widely explored, although only in a few instances have the products been unambiguously characterised (Figure 8). Ligand exchange can occur, but no complex in which one dithiocarbamate has been exchanged for another anionic bidentate ligand has been crystallographically characterised. Mixtures of $\left[\mathrm{Cu}\left(\mathrm{S}_{2} \mathrm{CNEt}_{2}\right)_{2}\right]$ and $\left[\mathrm{Cu}\left(\mathrm{Se}_{2} \mathrm{CNEt}_{2}\right)_{2}\right]$ are believed to rapidly equilibrate upon mixing to form $\left[\mathrm{Cu}\left(\mathrm{S}_{2} \mathrm{CNEt}_{2}\right)\left(\mathrm{Se}_{2} \mathrm{CNEt}_{2}\right)\right]$ as shown by EPR spectroscopy [55].

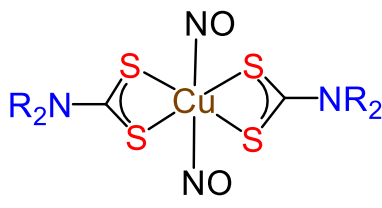

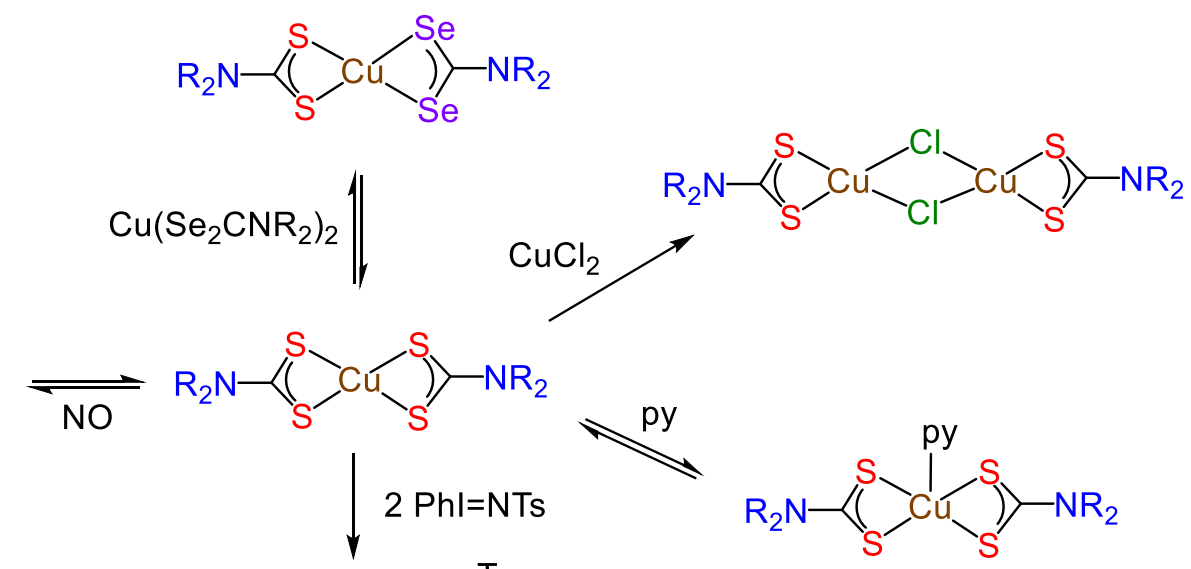

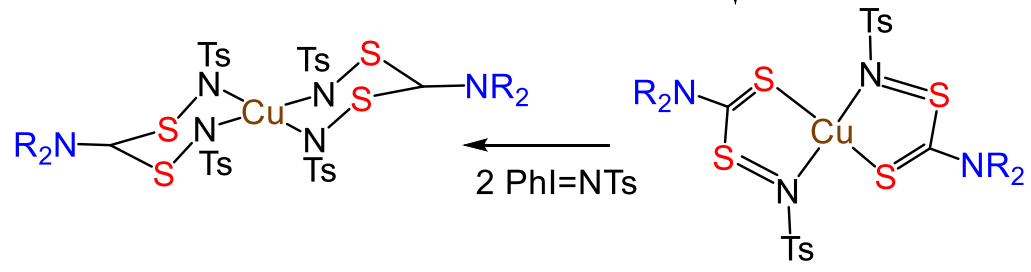

Figure 8. Selected reactions of $\left[\mathrm{Cu}\left(\mathrm{S}_{2} \mathrm{CNR}_{2}\right)_{2}\right]$.

The addition of $\mathrm{CuCl}_{2}$ to $\left[\mathrm{Cu}\left(\mathrm{S}_{2} \mathrm{CNR}_{2}\right)_{2}\right]$ leads to ligand redistribution and the formation of dimeric $\left[\mathrm{Cu}\left(\mathrm{S}_{2} \mathrm{CNR}_{2}\right)(\mu-\mathrm{Cl})\right]_{2}[65-67]$, a crystal structure of $\left[\mathrm{Cu}\left(\mathrm{S}_{2} \mathrm{CNEt}_{2}\right)(\mu-\mathrm{Cl})\right]_{2}$ confirming its identity. It consists of weakly associated dimers being held together by intermolecular $\mathrm{Cu}-\mathrm{C} 1(2.874 \AA)$ and $\mathrm{Cu}-\mathrm{S}(2.882 \AA)$ interactions [65]. Most complexes of 
this type are difficult to crystallise, possibly due to their equilibrium with monomers in solution [66]. A minor product of $\mathrm{CuCl}_{2}$ addition to $\left[\mathrm{Cu}\left(\mathrm{S}_{2} \mathrm{CNEt}_{2}\right)_{2}\right]$ is $\left[\mathrm{Cu}_{3}\left(\mathrm{~S}_{2} \mathrm{CNEt}_{2}\right) \mathrm{Cl}_{3}\right]$, a mixed-valence coordination polymer containing square planar $\mathrm{Cu}$ (II) and tetrahedral $\mathrm{Cu}(\mathrm{I})$ centres. The addition of $\mathrm{CuX} 2(\mathrm{X}=\mathrm{Cl}, \mathrm{Br})$ to $\left[\mathrm{Cu}\left(\mathrm{S}_{2} \mathrm{CNC}_{5} \mathrm{H}_{10}\right)_{2}\right]$ in $\mathrm{CHCl}_{3} / \mathrm{EtOH}$ is also reported to afford mixed-valence $\mathrm{Cu}(\mathrm{I})-\mathrm{Cu}(\mathrm{II})$ coordination polymers in which the halide-substituted centre has been reduced [68]. Related mixed-valence coordination polymers are also generated upon addition of $\mathrm{Cu}(\mathrm{I})$ halides and it may be that there is an error in this paper. If not, then there is clearly a fine balance between ligand-exchange and a one-electron reduction-oxidation upon addition of metal salts to $\left[\mathrm{Cu}\left(\mathrm{S}_{2} \mathrm{CNR}_{2}\right)_{2}\right]$. Photochemical reactions of $\left[\mathrm{Cu}\left(\mathrm{S}_{2} \mathrm{CNR}_{2}\right)_{2}\right]$ have been studied in a range of solvents. They utilise the strongly allowed ligand-metal charge transfer (LMCT) in the visible region, which leads to a reduction of the copper centre [69]. For example, laser pulse photolysis of $\left[\mathrm{Cu}\left(\mathrm{S}_{2} \mathrm{CNEt}_{2}\right)_{2}\right]$ in $\mathrm{CCl}_{4}$ induces a series of transformations resulting in the formation of binuclear $\left[\mathrm{Cu}_{2}\left(\mathrm{Et}_{2} \mathrm{dtc}\right)_{3} \mathrm{Cl}\right]$ and tetraethyl-thiuram disulfide [70]. The addition of nitrogen bases such as pyridine to $\left[\mathrm{Cu}\left(\mathrm{S}_{2} \mathrm{CNR}_{2}\right)_{2}\right]$ results in loss of the EPR signal, being suggested to result from the formation of adducts such as $\left[\mathrm{Cu}\left(\mathrm{S}_{2} \mathrm{CNR}_{2}\right)_{2} \cdot \mathrm{py}\right]$, although no such complexes have been isolated and fully characterised [71]. Water-soluble complexes such as $\left[\mathrm{Cu}\left\{\mathrm{S}_{2} \mathrm{CN}\left(\mathrm{CH}_{2} \mathrm{CH}_{2} \mathrm{OH}\right)_{2}\right\}_{2}\right]$ and $\left[\mathrm{Cu}\left\{\mathrm{S}_{2} \mathrm{CN}\left(\mathrm{CH}_{2} \mathrm{CO}_{2} \mathrm{H}\right)_{2}\right\}_{2}\right]$ trap one and two equivalents of $\mathrm{NO}$ in water as shown by spectrophotometric studies [30,72,73]. Stability constants for each binding process are highly dependent upon the nature of the substituents ranging from $10^{3}-10^{10}$ for binding of the first $\mathrm{NO}$ and $10^{2}-10^{4}$ for the second. A very unusual transformation occurs upon stirring $\left[\mathrm{Cu}\left(\mathrm{S}_{2} \mathrm{CNR}_{2}\right)_{2}\right]$ with the nitrene-source, $[\mathrm{PhI}=\mathrm{NTs}]_{n}$, which leads to sequential insertion of two and four nitrenes into the $\mathrm{Cu}-\mathrm{S}$ bonds (Figure 8) $[74,75]$. This reaction is not unique to copper and may initially result from nitrene addition to sulfur, which then rearranges to afford the ring-expanded product.

\section{Copper(III) Dithiocarbamate Complexes}

$\mathrm{Cu}$ (III) complexes are fairly common [76], although there has been a recent challenge to the simple view that copper is in the +3 state in these species [77]. $\mathrm{Cu}$ (III) dithiocarbamate complexes are accessible and relatively stable in the solid state. Most common are the bis(dithiocarbamate) cations, $\left[\mathrm{Cu}\left(\mathrm{S}_{2} \mathrm{CNR}_{2}\right)_{2}\right]^{+}$, which adopt a square planar coordination geometry. As discussed in the preceding section, $\left[\mathrm{Cu}\left(\mathrm{S}_{2} \mathrm{CNR}_{2}\right)_{2}\right]$ have a relatively low oxidation potential [78]; hence, the addition of a range of oxidising agents results in the formation of the analogous $\mathrm{Cu}(\mathrm{III})$ complexes. Common oxidants used are $\mathrm{I}_{2}$ [79-81], $(\mathrm{NO}) \mathrm{BF}_{4}$ [82], $\mathrm{InI}_{3}$ [83], [Cu( $\left.\mathrm{BF}\right)_{2}$ ] [84], polyoxometalates [85,86], [Cu( $\left.\left(\mathrm{ClO}_{4}\right)_{2}\right]$ [87-91] and $\mathrm{FeCl}_{3}$ [91]. Upon oxidation, brown solutions of $\left[\mathrm{Cu}\left(\mathrm{S}_{2} \mathrm{CNR}_{2}\right)_{2}\right]$ become green and the $\mathrm{Cu}$ (III) complexes often crystallise from the reaction medium. In the solid state, they retain their green colour upon standing in air, but in solution, attempts to run NMR spectra (for those with diamagnetic anions) lead to broad resonances. This is probably due (at least in part) to back reduction to $\left[\mathrm{Cu}\left(\mathrm{S}_{2} \mathrm{CNR}_{2}\right)_{2}\right]$, but EPR spectra also show other $\mathrm{Cu}$ (II) complexes that have not to date been fully characterised [79].

Shtyrlin and co-workers studied the oxidation of $\left[\mathrm{Cu}\left(\mathrm{S}_{2} \mathrm{CNEt}_{2}\right)_{2}\right]$ by $\mathrm{I}_{2}$ in $\mathrm{CH}_{2} \mathrm{Cl}_{2}$ in detail [92]. The initial formation of $\left[\mathrm{Cu}\left(\mathrm{S}_{2} \mathrm{CNEt}_{2}\right)_{2}\right]\left[\mathrm{I}_{3}\right]$ is reversible $(\log \mathrm{K}=5.8)$, as is further addition of $\mathrm{I}_{2}$ to give $\left[\mathrm{Cu}\left(\mathrm{S}_{2} \mathrm{CNEt}_{2}\right)_{2}\right]\left[\mathrm{I}_{5}\right](\log \mathrm{K}=2.02)$. Electron transfer between both of these $\mathrm{Cu}$ (III) species and $\left[\mathrm{Cu}\left(\mathrm{S}_{2} \mathrm{CNEt}_{2}\right)_{2}\right]$ is very fast $\left(\mathrm{k}_{\mathrm{e}}=3 \times 10^{8} \mathrm{M}^{-1} \cdot \mathrm{sec}^{-1}\right.$ at $298 \mathrm{~K})$. This has prompted a mechanism to be put forward that invokes the formation of an iodide-bridged intermediate, in which electron-density is delocalised across both copper centres and the bridging iodine(s). Bond and co-workers generated $\mathrm{Cu}(\mathrm{III})$ complexes upon the addition of $(\mathrm{NO}) \mathrm{BF}_{4}$ to $\left[\mathrm{Cu}\left(\mathrm{S}_{2} \mathrm{CNR}_{2}\right)_{2}\right]$, using these to acquire electrospray mass spectra, molecular ions being readily observed, while in some instances, sulfur-rich species were also seen [82]. Importantly, they found that mixing different $\mathrm{Cu}(\mathrm{III})$ dithiocarbamate cations led to global ligand exchange, showing that dithiocarbamates are also labile at the $\mathrm{Cu}(\mathrm{III})$ centre. 
As mentioned above, all contain a square planar centre with $\mathrm{Cu}-\mathrm{S}$ bond lengths of ca. $2.2 \AA$, some $0.1 \AA$ shorter than related Cu(II) complexes, as would be expected upon oxidation of the copper centre. Indeed, this small but reliable shortening is an easy way to determine the difference between $\mathrm{Cu}(\mathrm{II})$ and $\mathrm{Cu}(\mathrm{III})$ centres in mixed-valence complexes. As has been discussed previously $[3,83]$, several structural motifs are found in the solidstate, the form adopted being sensitive to the nature of the dithiocarbamate substituents and the anion. All show intermolecular interactions, either between cations through secondary $\mathrm{Cu} \cdots \mathrm{S}$ interactions as discussed for the related $\mathrm{Cu}$ (II) complexes, or between anions and cations. A common structural motif is a coordination polymer (Figure 9a), in which cations stack to give a distorted octahedral $\mathrm{CuS}_{6}$ coordination geometry and anions are separate as found in $\left[\mathrm{Cu}\left(\mathrm{S}_{2} \mathrm{CNEt}_{2}\right)_{2}\right]\left[\mathrm{FeCl}_{4}\right][91]$. The anions can also coordinate, giving rise to different structures. For example, $\left[\mathrm{Cu}\left(\mathrm{S}_{2} \mathrm{CNEt}_{2}\right)_{2}\right]\left[\mathrm{I}_{3}\right]$ is a coordination polymer with anions linking $\mathrm{Cu}(\mathrm{III})$ centres via $\mathrm{CuS}_{4} \mathrm{I}_{2}$ coordination geometry [79] (Figure 9b), while $\left[\mathrm{Cu}\left(\mathrm{S}_{2} \mathrm{CNMe}_{2}\right)_{2}\right]\left[\mathrm{ClO}_{4}\right]$ has a pair of $\mathrm{Cu}(\mathrm{III})$ centres capped by the anion [91] (Figure $9 \mathrm{c}$ ).

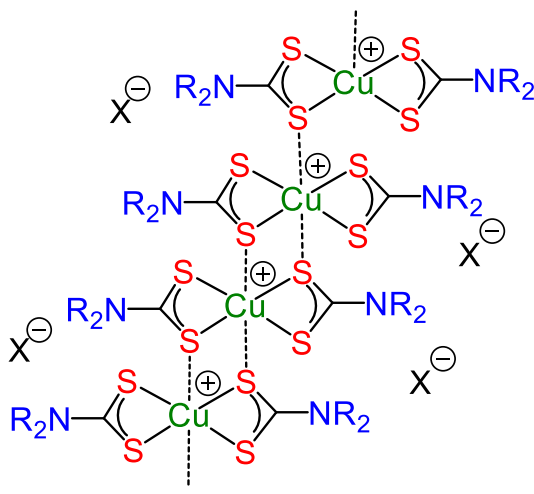

(a)

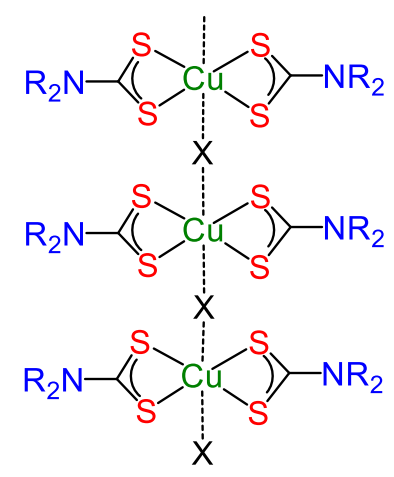

(b)

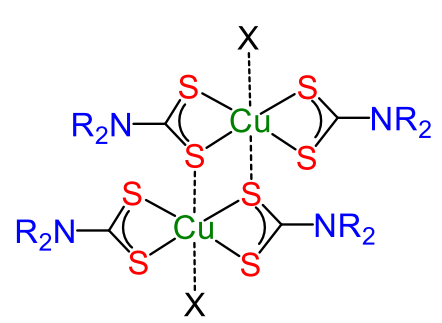

(c)

Figure 9. Line drawings of structural motifs (a-c) adopted by $\mathrm{Cu}(\mathrm{III})$ bis(dithiocarbamate) complexes.

Copper(III) dihalide complexes, [CuX $\left.{ }_{2}\left(\mathrm{~S}_{2} \mathrm{CNR}_{2}\right)\right]$, are also known and can also be accessed from the addition of thionyl chloride to $\left[\mathrm{Cu}\left(\mathrm{S}_{2} \mathrm{CNR}_{2}\right)_{2}\right]$ [93] or the oxidative addition of thiuram disulfides to $\mathrm{CuX}_{2}[13,78,94]$ (Figure 10). These complexes are diamagnetic, consistent with a square-planar $\mathrm{d}^{8}$ configuration and have been confirmed in a crystal structure of $\left[\mathrm{CuBr}_{2}\left(\mathrm{~S}_{2} \mathrm{CNBu}_{2}\right)\right]$ [95]. The average $\mathrm{Cu}-\mathrm{S}$ distance of 2193(6) $\AA$ is consistent with binding to a $\mathrm{Cu}(\mathrm{III})$ centre. The addition of $\mathrm{Cd}\left(\mathrm{CF}_{3}\right)_{2}$ to $\left[\mathrm{CuX} \mathrm{X}_{2}\left(\mathrm{~S}_{2} \mathrm{CNR}_{2}\right)\right]$ gives the dialkyl derivative, $\left[\mathrm{Cu}\left(\mathrm{CF}_{3}\right)_{2}\left(\mathrm{~S}_{2} \mathrm{CNEt}_{2}\right)\right]$, which has also been crystallographically characterised [96], as has $\left[\mathrm{Cu}\left(\mathrm{C}_{2} \mathrm{~F}_{5}\right)_{2}\left(\mathrm{~S}_{2} \mathrm{CNEt}_{2}\right)\right]$ prepared upon the addition of tetraethyl thiuram disulfide to $\mathrm{Cd}\left(\mathrm{C}_{2} \mathrm{~F}_{5}\right)_{2}$ [97], and contain a square planar $\mathrm{Cu}(\mathrm{III})$ centre.

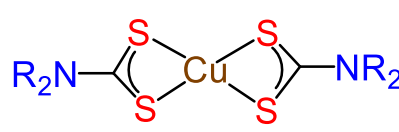<smiles></smiles><smiles></smiles><smiles></smiles><smiles>[R16]C(=S)SSC([R16])[R16]</smiles><smiles>[OH2+][C-]1C=C1</smiles>

$\oplus$

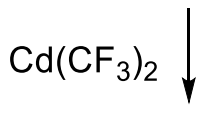

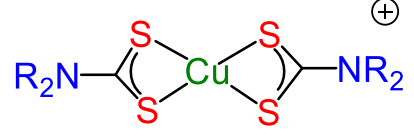<smiles></smiles>

Figure 10. Synthetic routes to $\mathrm{Cu}(\mathrm{III})$ dithiocarbamate complexes. 


\section{Copper(I) Dithiocarbamate Complexes}

Copper(I) dithiocarbamate complexes come in two main forms: As clusters in which the dithiocarbamates bind in a capping manner and as mononuclear species with phosphine or phosphite co-ligands. Tetranuclear clusters, $\left[\mathrm{Cu}\left(\mu_{3}-\mathrm{S}_{2} \mathrm{CNR}_{2}\right)\right]_{4}$, have been known since the 1960s [98], and can be prepared via three general methods: (i) The reduction of $\mathrm{Cu}$ (II) salts by $\mathrm{NH}_{2} \mathrm{OH} \cdot \mathrm{HCl}$ in the presence of dithiocarbamate salts [99], (ii) from the comproportionation of $\left[\mathrm{Cu}\left(\mathrm{S}_{2} \mathrm{CNR}_{2}\right)_{2}\right]$ and activated copper powder $[100,101]$ and (iii) the addition of thiuram disulfides to copper powder in organic media [102]. Quite recently, a further route was shown, namely the insertion of $\mathrm{CS}_{2}$ into a copper-amide bond [103]. All are yellow, and diamagnetic and crystal structures show they consist of a tetrahedral array of copper centres, with each face of the tetrahedron being capped by a dithiocarbamate ligand (Figure 11a). The disproportionation of $\left[\mathrm{Cu}\left(\mathrm{S}_{2} \mathrm{CNR}_{2}\right)_{2}\right]$ and $\left[\mathrm{Cu}\left(\mathrm{ClO}_{4}\right)_{2}\right]$ has been a well-developed route to $\mathrm{Cu}(\mathrm{III})$ dithiocarbamate complexes [79,84,90], but the nature of the $\mathrm{Cu}(\mathrm{I})$ complex remained unknown until Hogarth and co-workers isolated and crystallographically characterised $\left[\left\{\mathrm{Cu}\left(\mu_{4}-\mathrm{S}_{2} \mathrm{CNPr}_{2}\right)\right\}_{8}\right]\left[\mathrm{ClO}_{4}\right]_{2}$ from the reaction with $\left[\mathrm{Cu}\left(\mathrm{S}_{2} \mathrm{CNPr}_{2}\right)_{2}\right][100]$. This cluster dication (Figure 11b) consists of a cubic array of copper atoms with each square face of the cube capped by a dithiocarbamate. The average $\mathrm{Cu}-\mathrm{Cu}$ distance of $2.80 \AA$ is slightly longer than that of $2.70 \AA$ found in tetrahedral clusters [100], while in both, the $\mathrm{Cu}-\mathrm{S}$ distances are ca. $2.24-2.28 \AA$.

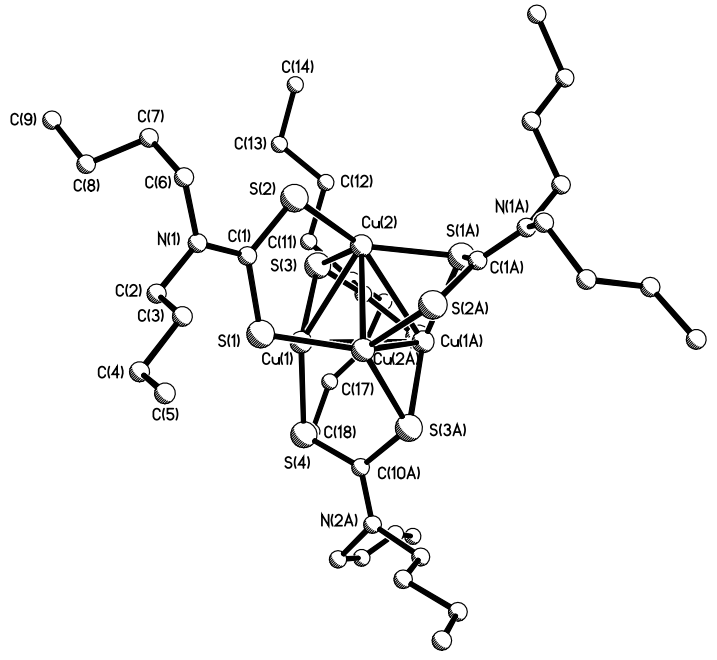

(a)

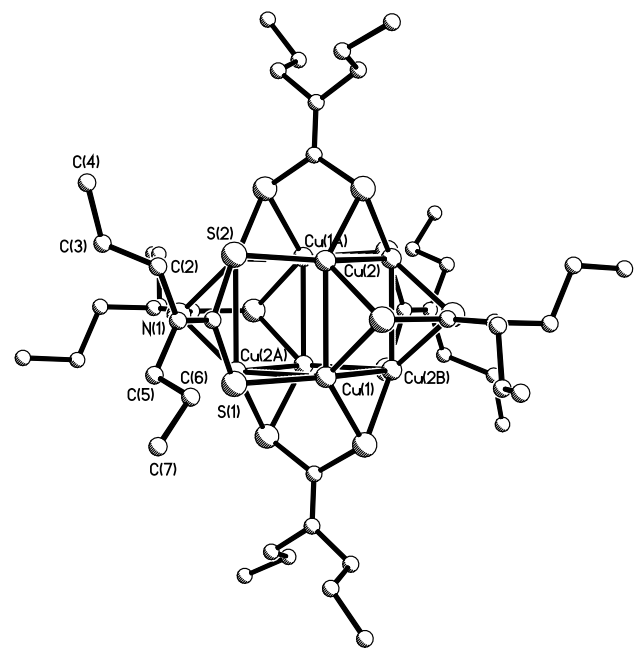

(b)

Figure 11. Molecular structures of $(\mathbf{a})\left[\left\{\mathrm{Cu}\left(\mu_{3}-\mathrm{S}_{2} \mathrm{CNBu}_{2}\right)\right\}_{4}\right]$ and $(\mathbf{b})$ cationic core in $\left.\left[\left\{\mathrm{Cu}\left(\mu_{4}-\mathrm{S}_{2} \mathrm{CNPr}_{2}\right)\right\}_{8}\right][\mathrm{ClO}]_{4}\right]_{2}$. Reproduced with permission from [100]. Copyright 2006 Elsevier.

The addition of thiuram disulfide (TDS) to $\mathrm{Cu}(\mathrm{I})$ clusters leads to oxidation and the formation of $\left[\mathrm{Cu}\left(\mathrm{S}_{2} \mathrm{CNR}_{2}\right)_{2}\right]$, and the kinetics and mechanism have been studied [104]. Reactions are proposed to proceed via a rapid equilibrium with adducts $\left[\mathrm{Cu}\left(\mathrm{S}_{2} \mathrm{CNR}_{2}\right)(\mathrm{TDS})\right]$, which undergo intramolecular electron transfer in a rate-determining step to afford the final $\mathrm{Cu}(\mathrm{II})$ complexes.

Over the past decade, through the work of Liu and co-workers, the range of copperdithiocarbamate clusters has expanded greatly including examples containing hydrides [105-108] and acetylides [109-113] with up to 25 copper atoms. More widely studied are the interconvertible hydride clusters $\left[\mathrm{Cu}_{7} \mathrm{H}\left(\mu_{3 / 4}-\mathrm{S}_{2} \mathrm{CNR}_{2}\right)_{6}\right]$ and $\left[\mathrm{Cu}_{8} \mathrm{H}\left(\mu_{4}{ }^{-}\right.\right.$ $\left.\left.\mathrm{S}_{2} \mathrm{CNR}_{2}\right)_{6}\right]^{+}$[108] (Figure 12). They are accessible via a number of routes, all involving the addition of $\left[\mathrm{BH}_{4}\right]^{-}$to $\mathrm{Cu}(\mathrm{I})$ or $\mathrm{Cu}(\mathrm{II})$ salts. Thus, octanuclear $\left[\mathrm{Cu}_{8} \mathrm{H}\left(\mu-\mathrm{S}_{2} \mathrm{CNR}_{2}\right)_{6}\right]^{+}$ results upon the addition of $\left[\mathrm{BH}_{4}\right]^{-}$to $\left[\mathrm{Cu}\left(\mathrm{S}_{2} \mathrm{CNR}_{2}\right)_{2}\right]$, a process that can be reversed with the loss of $\mathrm{H}_{2}$ upon oxidation by $\mathrm{Ce}(\mathrm{IV})$. The removal of one copper and the formation of heptanuclear $\left[\mathrm{Cu}_{7} \mathrm{H}\left(\mu_{3}-\mathrm{S}_{2} \mathrm{CNR}_{2}\right)_{6}\right]$ occurs upon further addition of $\left[\mathrm{BH}_{4}\right]^{-}$, a 


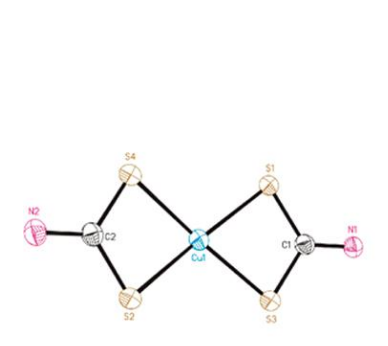

transformation reversed upon the addition of $\mathrm{Cu}(\mathrm{I})$ sources. Octanuclear clusters have a tetracapped-tetahedral cluster core, the dithiocarbamates forming a distorted icosahedron around this, with each adopting a $\mathrm{m}_{4}$-coordination mode. Heptanuclear clusters result from the removal of one outer copper centre and contain a tri-capped tetrahedral core, the dithiocarbamates again forming an icosahedron around this, but now some are $\mu_{3}$ binding and others $\mu_{4}$. In both types, the hydride lies within the central tetrahedron (interstitial) and can be observed in the ${ }^{1} \mathrm{H}$ NMR spectrum. The change from a cube to a tetra-capped tetrahedral metal array upon the introduction of the hydride is unexpected, but density functional theory (DFT) calculations of $\mathrm{S}_{2} \mathrm{CNH}_{2}$ model clusters support this structural change [108].
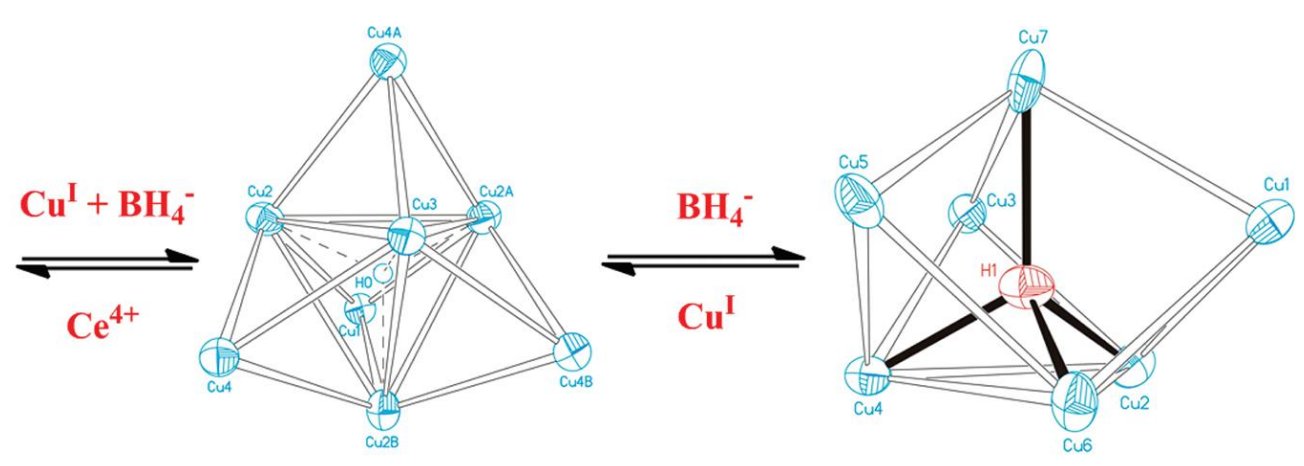

Figure 12. Interconversion of $\left[\mathrm{Cu}\left(\mathrm{S}_{2} \mathrm{CNR}_{2}\right)_{2}\right]$ with $\left[\mathrm{Cu}_{8} \mathrm{H}\left(\mu-\mathrm{S}_{2} \mathrm{CNR}_{2}\right)_{6}\right]^{+}$and $\left[\mathrm{Cu}_{7} \mathrm{H}\left(\mu_{3}-\mathrm{S}_{2} \mathrm{CNR}_{2}\right)_{6}\right]$ upon addition of $\left[\mathrm{BH}_{4}\right]^{-}$ and oxidation, respectively. Reproduced with permission from [108]. Copyright 2012 American Chemical Society.

In 2014, this chemistry was extended in a quite unexpected way, with the addition of excess $\left[\mathrm{BH}_{4}\right]^{-}$to $\mathrm{Cu}_{8}$ clusters affording molecular nanoscale clusters $\left[\mathrm{Cu}_{28}(\mathrm{H})_{15}\left(\mu_{4}{ }^{-}\right.\right.$ $\left.\left.\mathrm{S}_{2} \mathrm{CNR}_{2}\right)_{12}\right]\left[\mathrm{PF}_{6}\right]$ [106] (Figure 13a). The core consists of an irregular $\mathrm{Cu}_{4}$ tetrahedron, encapsulated by a rhombicuboctahedral framework containing $24 \mathrm{Cu}$ atoms (Figure 13b), the 12 square faces of which are capped by a dithiocarbamate. The ${ }^{1} \mathrm{H}$ NMR spectrum shows three hydride signals in a 1:8:6 ratio, and a neutron diffraction study allows these to be associated with (i) an interstitial hydride within the $\mathrm{Cu}_{4}$ tetrahedron, (ii) eight hydrides capping triangular faces of the rhombicuboctahedron and (iii) two sets of $\mu_{5}$ (four) and $\mu_{6}$ (two) of square-face truncating hydrides. The chemical equivalence in solution of this latter set as well as all dithiocarbamate ligands is associated with a rapid reorientation of the central $\mathrm{Cu}_{4}$ unit on the NMR timescale. Upon heating to $70-80^{\circ} \mathrm{C}$ (alone or in the presence of acids) or upon solar irradiation, these nanoclusters decompose to furnish $\mathrm{H}_{2}$ and generate both $\mathrm{Cu}_{7}$ and $\mathrm{Cu}_{8}$ clusters, along with $\mathrm{Cu}_{2} \mathrm{~S}$. This then links these three cluster types while also showing how other copper-dithiocarbamate complexes may decompose to copper-sulfides (see later).

The hydrides in these $\mathrm{Cu}_{28}$ clusters are sufficiently acidic deprotonate alkynes, and this has been exploited to afford acetylide-containing clusters [109-111]. Thus, $\left[\mathrm{Cu}_{28}(\mathrm{H})_{15}\left(\mu_{4}{ }^{-}\right.\right.$ $\left.\left.\mathrm{S}_{2} \mathrm{CNR}_{2}\right)_{12}\right]^{+}$reacts with terminal alkynes with $\mathrm{H}_{2}$ evolution to give $\mathrm{Cu}_{13}$ clusters $\left[\mathrm{Cu}_{13}\left(\mu_{4^{-}}\right.\right.$ $\left.\left.\mathrm{S}_{2} \mathrm{CNR}_{2}\right)_{6}\left(\mu_{3}-\mathrm{C} \equiv \mathrm{CR}\right)_{4}\right]^{+}$(Figure $\left.1 \mathrm{a}\right)$, which contain a centred cuboctahedral $\left[\mathrm{Cu}_{13}\right]^{11+}$ core, being identical to that found in face-centred cubic bulk copper [110]. There are two cluster core electrons and thus, unlike other copper-dithiocarbamate clusters discussed to date, they are mixed-valence complexes containing both $\mathrm{Cu}(\mathrm{I})$ and $\mathrm{Cu}(0)$ centres. The $\mathrm{Cu}_{13}$ core is capped by acetylides on four of the triangular faces, while each square face is capped with a dithiocarbamate. It is also possible to prepare clusters containing both hydride and acetylide ligands. Thus, when a ten-fold excess of $\mathrm{PhC}_{2} \mathrm{H}$ is reacted with $\left[\mathrm{Cu}_{28}(\mathrm{H})_{15}\left(\mu_{4}-\mathrm{S}_{2} \mathrm{CNR}_{2}\right)_{12}\right]^{+}$at $30^{\circ} \mathrm{C}$, mixtures of $\left[\mathrm{Cu}_{8} \mathrm{H}\left(\mu-\mathrm{S}_{2} \mathrm{CNR}_{2}\right)_{6}\right]^{+}$and the new clusters $\left[\mathrm{Cu}_{15}(\mathrm{H})_{2}\left(\mathrm{~S}_{2} \mathrm{CNR}_{2}\right)_{6}(\mathrm{C} \equiv \mathrm{CPh})_{6}\right]^{+}$result (Figure $\left.14 \mathrm{~b}\right)$. The latter was shown to be intermediates en-route to $\left[\mathrm{Cu}_{13}\left(\mu_{4}-\mathrm{S}_{2} \mathrm{CNR}_{2}\right)_{6}\left(\mu_{3}-\mathrm{C} \equiv \mathrm{CPh}\right)_{4}\right]^{+}[109]$. The $\mathrm{Cu}_{15}$ clusters are also accessible in higher yields from the simple addition of mixtures of dithiocarbamate salts and phenylacetylene to $\left[\mathrm{Cu}(\mathrm{MeCN})_{4}\right]^{+} / \mathrm{NaBH}_{4}$ mixtures in the presence of base. They 
contain an icosahedral $\mathrm{Cu}_{12}$ core, two faces of which are capped, while the final copper atom is encapsulated as a linear $\left[\mathrm{CuH}_{2}\right]^{-}$moiety (Figure $14 \mathrm{~b}$ ).

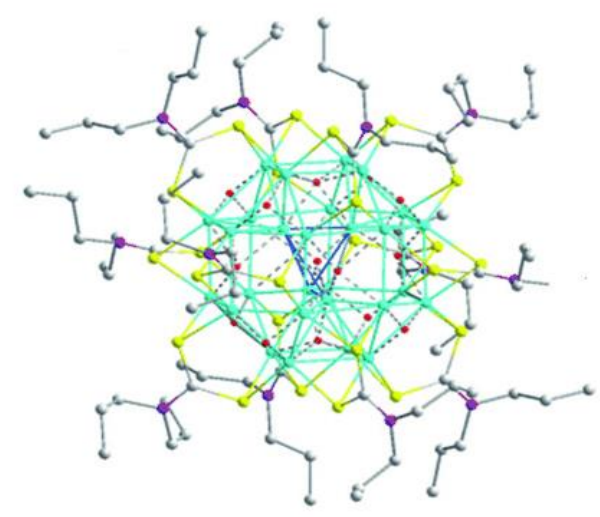

(a)

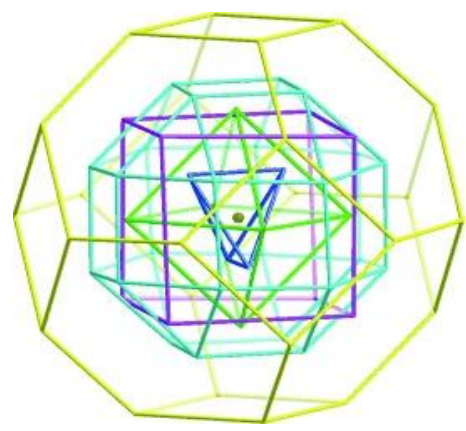

(b)

Figure 13. (a) Molecular structure of the cation in $\left[\mathrm{Cu}_{28}(\mathrm{H})_{15}\left(\mu_{4}-\mathrm{S}_{2} \mathrm{CNR}_{2}\right)_{12}\right]\left[\mathrm{PF}_{6}\right]$ and (b) a representation of the cluster core framework in which a $\mathrm{Cu}_{4}$ tetrahedron is encapsulated by a rhombicuboctahedral $C_{18}$ moiety. Reproduced with permission from [106]. Copyright 2014 John Wiley and Sons.

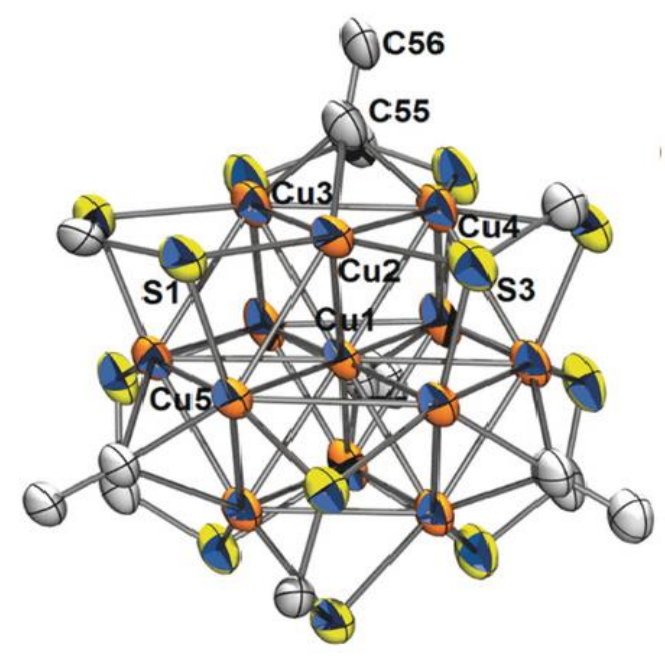

(a)

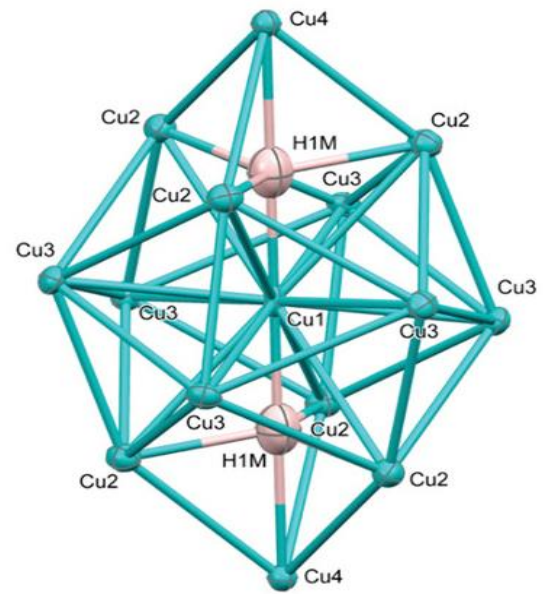

(b)

Figure 14. (a) Molecular suture of $\left[\mathrm{Cu}_{13}\left(\mu_{4}-\mathrm{S}_{2} \mathrm{CNR}_{2}\right)_{6}\left(\mu_{3}-\mathrm{C} \equiv \mathrm{CR}\right)_{4}\right]^{+}$and (b) cluster core geometry of $\left[\mathrm{Cu}_{15}(\mathrm{H})_{2}\left(\mathrm{~S}_{2} \mathrm{CNR}_{2}\right)_{6}(\mathrm{C} \equiv \mathrm{CPh})_{6}\right]^{+}$. Reproduced with permission from [110]. Copyright 2016 John Wiley and Sons.

The $\mathrm{Cu}_{13}$ clusters are reactive, easily losing a single metal atom to generate a number of related $\mathrm{Cu}_{12}$ clusters including $\left[\mathrm{Cu}_{12}\left(\mu_{12}-\mathrm{S}\right)\left(\mu_{4}-\mathrm{S}_{2} \mathrm{CNR}_{2}\right)_{6}\left(\mu_{3}-\mathrm{C} \equiv \mathrm{CR}\right)_{4}\right]$ and $\left[\mathrm{Cu}_{12}\left(\mu_{12^{-}}\right.\right.$ $\left.\mathrm{Cl})\left(\mu_{3}-\mathrm{Cl}\right)\left(\mu_{4}-\mathrm{S}_{2} \mathrm{CNR}_{2}\right)_{6}\left(\mu_{4}-\mathrm{C} \equiv \mathrm{CR}\right)_{4}\right]$ formed upon the addition of $\mathrm{KS}_{2} \mathrm{CNR}_{2}$ and simple dissolution in $\mathrm{CH}_{2} \mathrm{Cl}_{2}$, respectively [111]. All contain a $\mathrm{Cu}_{12}$ cuboctahedron with the new heteroatom encapsulated within the structure. Incorporation of other metals is also possible $[105,109]$. The reaction of $\left[\mathrm{Cu}_{15}(\mathrm{H})_{2}\left(\mathrm{~S}_{2} \mathrm{CNBu}^{\mathrm{i}}{ }_{2}\right)_{6}(\mathrm{C} \equiv \mathrm{CPh})_{6}\right]^{+}$with $\left[\mathrm{AuCl}\left(\mathrm{PPh}_{3}\right)\right]$ affords $\left[\mathrm{Au} @ \mathrm{Cu}_{12}\left(\mathrm{~S}_{2} \mathrm{CNBu}_{\mathrm{i} 2}\right)_{6}(\mathrm{C} \equiv \mathrm{CPh})\right]^{+}$, a highly luminescent cluster suggested to contain an $\mathrm{Au} @ \mathrm{Cu}_{12}$ alloy core [109], while the central copper centre can also be replaced by silver. Central doping with $\mathrm{Ag}$ or $\mathrm{Au}$ significantly affects the physiochemical properties as manifested in the dramatic quantum yield enhancement of $\left[\mathrm{Au} @ \mathrm{Cu}_{12}\left(\mathrm{~S}_{2} \mathrm{CNBu}_{2}\right)_{6}(\mathrm{C} \equiv \mathrm{CPh})_{4}\right]^{+}$ measured at 0.59 at $77 \mathrm{~K}$. Palladium-containing $\left[\mathrm{PdCu}_{14} \mathrm{H}_{2}\left(\mathrm{~S}_{2} \mathrm{CNBu}_{2}{ }_{2}\right)_{6}(\mathrm{C} \equiv \mathrm{CPh})_{6}\right]$ re- 
sults from the addition of $\mathrm{PhC}_{2} \mathrm{H}$ to $\left[\mathrm{Cu}_{28}(\mathrm{H})_{15}\left(\mu_{4}-\mathrm{S}_{2} \mathrm{CNBu}^{\mathrm{i}}{ }_{2}\right)_{12}\right]^{+}$in the presence of $\left[\mathrm{PdCl}_{2}\left(\mathrm{PPh}_{3}\right)_{2}\right]$ [105]. A neutron diffraction study shows that it contains a $\left[\mathrm{PdH}_{2}\right]^{-}$unit encapsulated with the bicapped-icosahedral $\mathrm{Cu}_{14}$ core. These studies are ongoing and, undoubtedly, further novel $\mathrm{Cu}(\mathrm{I})$ dithiocarbamate clusters will be reported in the near future.

As detailed earlier (Figure 7), $\left[\mathrm{Cu}\left(\mathrm{S}_{2} \mathrm{CNR}_{2}\right)_{2}\right]$ can be quasi-reversibly reduced to $\mathrm{Cu}(\mathrm{I})$ anions, $\left[\mathrm{Cu}\left(\mathrm{S}_{2} \mathrm{CNR}_{2}\right)_{2}\right]^{-}$, but until recently, no examples of these anionic $\mathrm{Cu}(\mathrm{I})$ complexes had ever been isolated, with all attempts leading to loss of a dithiocarbamate ligand with concomitant formation of $\mathrm{Cu}(\mathrm{I})$ clusters $\left[\mathrm{Cu}\left(\mathrm{S}_{2} \mathrm{CNR}_{2}\right)\right]_{n}$. In 2013, Teske reported the preparation and crystal structure of $\left[\mathrm{NH}_{4}\right]\left[\mathrm{Cu}\left(\mathrm{S}_{2} \mathrm{CNH}_{2}\right)_{2}\right] \cdot \mathrm{H}_{2} \mathrm{O}$, formed upon the addition of $\left[\mathrm{NH}_{4}\right]\left[\mathrm{S}_{2} \mathrm{CNH}_{2}\right]$ to $\mathrm{CuSO}_{4}$ in the presence of $\mathrm{KCN}$ [114]. Somewhat unexpectedly, however, the structure does not show the expected $\left[\mathrm{Cu}\left(\mathrm{S}_{2} \mathrm{CNH}_{2}\right)_{2}\right]^{-}$anion, but rather is a coordination polymer in which each dithiocarbamate ligand spans two copper centres (Figure 15a). This affords a stacked 2D framework, which includes a staggered chain of $\left[\mathrm{NH}_{4}\right]^{+}$and water molecules (Figure $15 \mathrm{~b}$ ). When a similar reaction is carried out at ca. $80-95{ }^{\circ} \mathrm{C}$, a second coordination polymer $\left[\mathrm{Cu}\left(\mathrm{S}_{2} \mathrm{CNH}_{2}\right)\right]_{n}$ results. While each copper remains bound to four dithiocarbamates, the $\mathrm{CuS}_{4}$ tetrahedral are now linked in a 3D array reminiscent of a filled $\beta$-cristobalite structure [114].

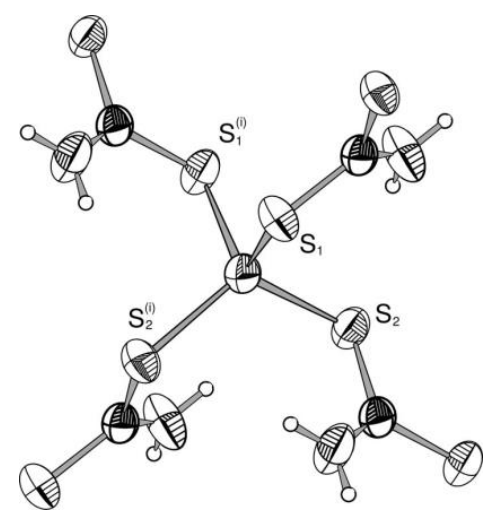

(a)

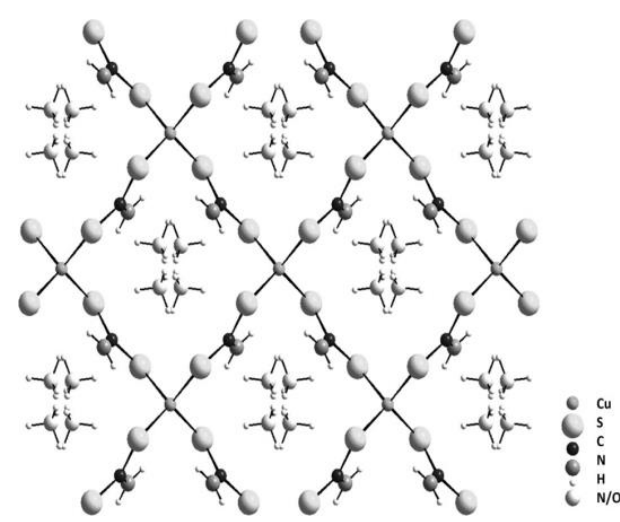

(b)

Figure 15. Representations of the solid-state structure of $\left[\mathrm{NH}_{4}\right]\left[\mathrm{Cu}\left(\mathrm{S}_{2} \mathrm{CNH}_{2}\right)_{2}\right] \cdot \mathrm{H}_{2} \mathrm{O}$ showing (a) the coordination geometry around each $\mathrm{Cu}(\mathrm{II})$ ion and $(\mathbf{b})$ the $2 \mathrm{D}$ framework. Reproduced with permission from [114]. Copyright 2013 John Wiley and Sons.

A second well-developed class of $\mathrm{Cu}(\mathrm{I})$ dithiocarbamate complexes are those containing phosphine (and to a lesser extent phosphite) co-ligands, first reported in the late 1960s $[115,116]$ and now relatively common $[101,117-119]$. Two general types are accessible, mononuclear four-coordinate complexes $\left[\mathrm{Cu}\left(\mathrm{S}_{2} \mathrm{CNR}_{2}\right)\left(\mathrm{PR}_{3}\right)_{2}\right]$ ((Figure 16a) or $\left[\mathrm{Cu}\left(\mathrm{S}_{2} \mathrm{CNR}_{2}\right)\left(\kappa_{2}-\mathrm{R}_{2} \mathrm{PXPR}_{2}\right)\right]$ with a $\mathrm{Cu}: \mathrm{P}$ ratio of $1: 2[116,118,120-126]$ and binuclear $[\mathrm{Cu}(\mu-$ $\left.\left.\mathrm{S}_{2} \mathrm{CNR}_{2}\right)\left(\mathrm{PR}_{3}\right)\right]_{2}$, in which the dithiocarbamates bridge the $\mathrm{Cu}_{2}$ centre (Figure 16b) [119] [119,127]. They result upon the addition of phosphines to $\mathrm{Cu}(\mathrm{I})$ dithiocarbamate clusters $[101,115]$, while the bis(adducts) are also accessible from reactions of $\left[\mathrm{CuX}\left(\mathrm{PR}_{3}\right)_{2}\right]$ with dithiocarbamate salts $[122,124,126]$. Mononuclear adducts appear to be quite robust in both solution and the solid state. They contain a tetrahedral $\mathrm{Cu}(\mathrm{I})$ centre that is somewhat distorted due to the small bite angle of the dithiocarbamate. Loss of phosphine affords the binuclear complexes, which are less stable, especially in solution, being stable in benzene but not toluene [119]. In the solid state, the central $\mathrm{Cu}_{2} \mathrm{~S}_{2}$ ring is planar and $\mathrm{Cu} \cdots \mathrm{Cu}$ distances vary at 2.6-2.9 $\AA$. Huang and co-workers prepared a binuclear complex (Figure 16c) in which the two $\mathrm{Cu}(\mathrm{I})$ centres are linked via a piperazine-bis(dithiocarbamate) ligand [128], while from reactions of borohydride adducts $\left[\mathrm{Cu}\left(\mathrm{\kappa}_{2}-\mathrm{BH}_{4}\right)\left(\mathrm{PR}_{3}\right)_{2}\right]$ with $\mathrm{PhNCS}$, Orlandini and co-workers prepared a number of mononuclear bis(phosphine) complexes containing an aniline-derived dithiocarbamate ligand, such as $\left[\mathrm{Cu}\left(\mathrm{S}_{2} \mathrm{CNHPh}\right)\left(\mathrm{PR}_{3}\right)_{2}\right]$ $(\mathrm{R}=\mathrm{Ph}, \mathrm{Cy})$, one of which $(\mathrm{R}=\mathrm{Ph})$ (Figure $16 \mathrm{~d})$ has been crystallographically characterised [129]. The structure is as expected, but the stability of the primary dithiocarbamate 
is unexpected given the lack of substantive evidence for analogous $\mathrm{Cu}$ (II) complexes. Likely, this results from the soft nature of the $\mathrm{Cu}(\mathrm{I}) \mathrm{vs}$. $\mathrm{Cu}$ (II) centre, which makes deprotonation, with concomitant formation of a dithiocarbamate, less favourable.<smiles>[R]N([R])C1=[SH][Ge]([R5])([R5])S1</smiles>

(a)

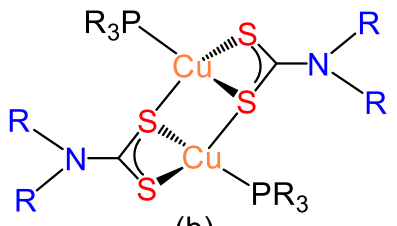

(b)<smiles>Pc1ccccc1</smiles>

(d)

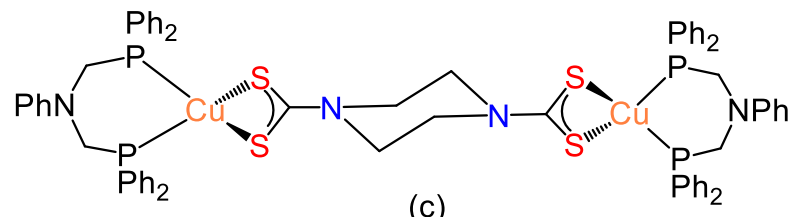

(c)

Figure 16. Line drawings of various $\mathrm{Cu}(\mathrm{I})$ phosphine-containing dithiocarbamate complexes (a-d).

Trinuclear phosphine-containing $\mathrm{Cu}(\mathrm{I})$ clusters, $\left[\mathrm{Cu}_{3}\left(\mu_{3}-\mathrm{S}_{2} \mathrm{CNR}_{2}\right)_{2}(\text { diphosphine })_{2}\right]^{+}$, have also recently been prepared from the addition of dithiocarbamate salts to $\left[\mathrm{Cu}(\mathrm{MeCN})_{4}\right]\left[\mathrm{PF}_{6}\right]$ in the presence of the diphosphine [107]. The $\mathrm{Cu}_{3}$ triangle is capped by two dithiocarbamates, and one copper is chelated by a diphosphine while the second bridges a $\mathrm{Cu}-\mathrm{Cu}$ vector (Figure 17a). There is one report of an unusual phosphine-chloride-containing cluster, namely $\left[\mathrm{Cu}_{3}\left(\mathrm{PEt}_{3}\right)_{3}(\mu-\mathrm{Cl})\left(\mu_{3}-\mathrm{Cl}\right)\left(\mu_{3}-\mathrm{S}_{2} \mathrm{CNC}_{4} \mathrm{H}_{8}\right)\right]$ (Figure 17b), formed from the 1:2:1 reaction between $\mathrm{CuCl}, \mathrm{Et}_{3} \mathrm{P}$ and $\mathrm{NH}_{4}\left[\mathrm{~S}_{2} \mathrm{CNC}_{4} \mathrm{H}_{8}\right]$ [130]. It contains an incomplete cubane core and can be envisaged as the monomer $\left[\mathrm{Cu}\left(\mathrm{PEt}_{3}\right)\left(\mathrm{S}_{2} \mathrm{CNC}_{4} \mathrm{H}_{8}\right)\right]$ being "trapped" by $\left[\mathrm{CuCl}\left(\mathrm{PEt}_{3}\right)\right]_{2}$ en-route to binuclear $\left[\mathrm{Cu}\left(\mathrm{PR}_{3}\right)\left(\mu-\mathrm{S}_{2} \mathrm{CNR}_{2}\right)\right]_{2}[119]$.

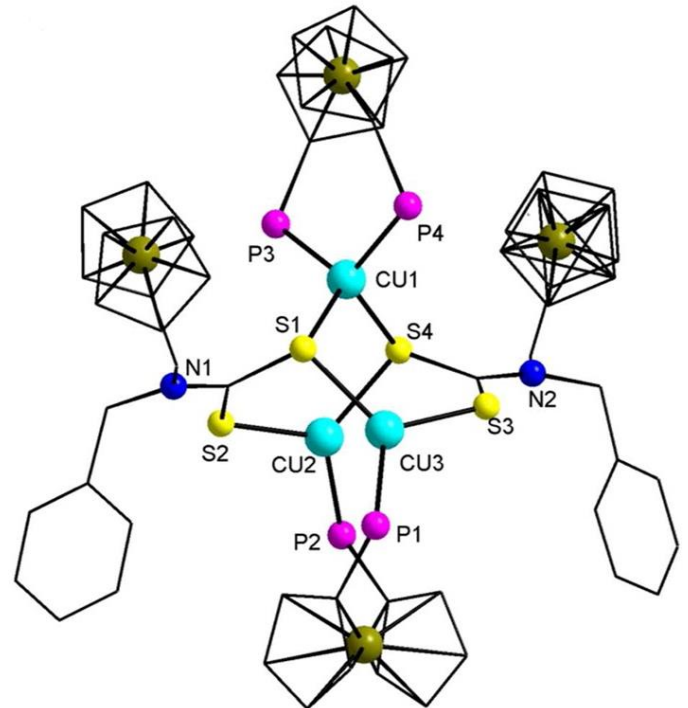

(a)

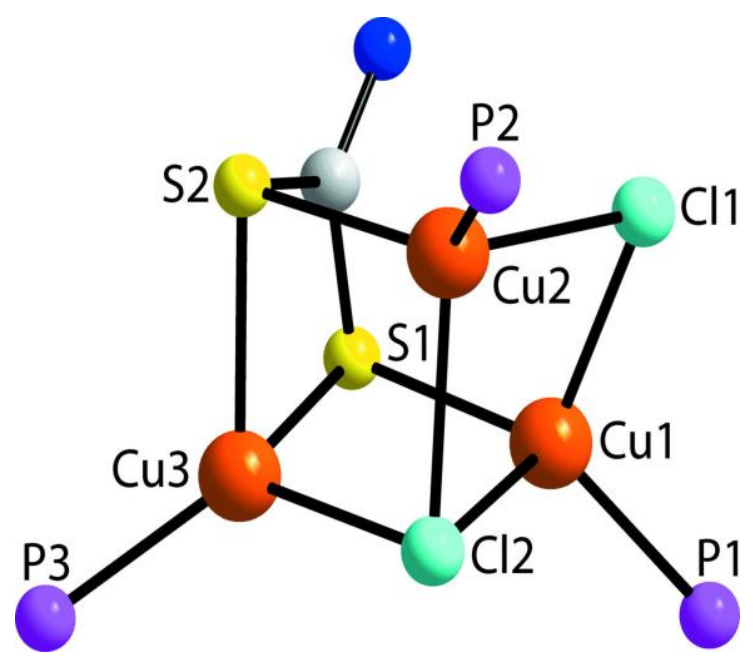

(b)

Figure 17. Molecular structures of (a) the cation $\left[\mathrm{Cu}_{3}\left\{\mu_{3}-\mathrm{S}_{2} \mathrm{CN}(\mathrm{Bz})(\mathrm{Fc})\right\}_{2}(\mu-\mathrm{dppf})_{2}\right]^{+}$and $(\mathbf{b})$ the cluster core of $\left[\mathrm{Cu}_{3}\left(\mathrm{PEt}_{3}\right)_{3}(\mu-\right.$ $\left.\mathrm{Cl})\left(\mu_{3}-\mathrm{Cl}\right)\left(\mu_{3}-\mathrm{S}_{2} \mathrm{CNC}_{4} \mathrm{H}_{8}\right)\right]$. Reproduced with permission from [107]. Copyright 2016 American Chemical Society, and IUCr [130].

There are a small number of further $\mathrm{Cu}(\mathrm{I})$ phosphine-dithiocarbamate complexes, which have been characterised primarily on the basis of only a crystallographic study. These include $\left[\mathrm{Cu}_{2}(\mu-\mathrm{dppm})_{2}\left(\mu-\mathrm{S}_{2} \mathrm{CNEt}_{2}\right)\right]\left[\mathrm{ClO}_{4}\right]\left(\mathrm{dppm}=\mathrm{Ph}_{2} \mathrm{PCH}_{2} \mathrm{PPh}_{2}\right)$ with mutually trans diphosphines and a short $\mathrm{Cu} \cdot \mathrm{Cu}$ vector $(2.711(1) \AA)[131],\left[\mathrm{Cu}_{3}(\mu-\mathrm{dppm})_{3}\left(\mu_{3}\right.\right.$ - 
$\left.\left.\mathrm{S}_{2} \mathrm{CNR}_{2}\right)\left(\mu_{3}-\mathrm{I}\right)\right] \mathrm{I}$, which contains a $\mathrm{Cu}_{3}$ triangle in which each edge is bridged by a diphosphine and the faces by iodide and dithiocarbamate, respectively [122] and octanuclear $\left[\mathrm{Cu}_{8}(\mathrm{SAr})_{4}(\mathrm{SAr})_{2}\left(\mathrm{~S}_{2} \mathrm{CNMe}_{2}\right)_{2}\right]\left[\mathrm{PPh}_{4}\right]_{2}\left(\mathrm{Ar}=4-\mathrm{SC}_{6} \mathrm{H}_{4} \mathrm{Br}\right)$ [132]. The centrosymmetric cluster core contains eight copper and ten sulfur atoms with all copper atoms bound to three sulfurs of either thiolate or triply bridging dithiocarbamate ligands. Four of the copper atoms are also coordinated to a $\mathrm{PPh}_{3}$ ligand and have a distorted tetrahedral geometry while the others have a distorted trigonal-planar coordination.

\section{Mixed-Valence Copper Dithiocarbamate Complexes}

As one might imagine given the rich nature of the chemistry of $\mathrm{Cu}(\mathrm{I}), \mathrm{Cu}(\mathrm{II})$ and $\mathrm{Cu}$ (III) dithiocarbamates described above, and the relatively low potentials that link these three oxidation states, there is a rich and diverse mixed-valence copper-dithiocarbamate chemistry. This is primarily focused on $\mathrm{Cu}(\mathrm{I})-\mathrm{Cu}(\mathrm{II})$ complexes, many of which are coordination polymers, but there are also a reasonable number of $\mathrm{Cu}(\mathrm{II})-\mathrm{Cu}(\mathrm{III})$ examples. For this reason, this section is subdivided into two separate subsections, with some slight overlap from a single complex which contains copper in all three oxidation states.

Mixed valence $\mathrm{Cu}(\mathrm{I})-\mathrm{Cu}(\mathrm{II})$ complexes were first detailed in 1974, with Golding and co-workers reporting the formation of coordination polymers from the addition of $\mathrm{CuX}_{2}$ $(\mathrm{X}=\mathrm{Cl}, \mathrm{Br})$ to the piperidine dithiocarbamate complex, $\left[\mathrm{Cu}\left(\mathrm{S}_{2} \mathrm{CNC}_{5} \mathrm{H}_{10}\right)_{2}\right]$, in $\mathrm{EtOH} / \mathrm{CHCl}_{3}$ [68]. Isolated complexes had the formulae $\left[\mathrm{Cu}\left(\mathrm{S}_{2} \mathrm{CNC}_{5} \mathrm{H}_{10}\right)_{2}(\mathrm{CuX})_{n}\right]$ $(n=4,6)$ and were found to be insoluble in common organic solvents, and decomposed to give the starting $\mathrm{Cu}$ (II) dithiocarbamate in polar coordinating solvents such as DMSO, DMF and pyridine. It is not clear what reduces $\mathrm{CuX}$ but it likely results from dithiocarbamate oxidation. Two of these were crystallographically characterised $(\mathrm{X}=\mathrm{Br})$ but disorder makes them quite difficult to fully interpret on a molecular scale.

There was little further activity in this area until 2005 when Okubo and co-workers reported the structure of $\left[\mathrm{Cu}_{5}\left(\mathrm{~S}_{2} \mathrm{CNEt}_{2}\right)_{2} \mathrm{Cl}_{3}\right]\left[\mathrm{FeCl}_{4}\right]$ (Figure 18a) formed upon the addition of $\mathrm{CuCl}_{2}$ to $\left[\mathrm{Fe}\left(\mathrm{S}_{2} \mathrm{CNEt}_{2}\right)_{3}\right]$ in an acetone $/ \mathrm{CHCl}_{3}$ mix [133]. It contains a single $\mathrm{Cu}$ (II) centre, as supported by magnetic measurements, and the $\mathrm{Cu}_{5}$ sub-units are linked through the $\mathrm{Cu}$ (II) centres to afford a 2D lattice with the $\left[\mathrm{FeCl}_{4}\right]^{-}$counter ions located between the sheets. The material shows interesting physical properties, for example temperature dependence of the dielectric constants shows 2-D ferroelectric order.

Following this initial report, over the past 15 years, Okubo and co-workers have prepared a range of $\mathrm{Cu}(\mathrm{I})-\mathrm{Cu}(\mathrm{II})$ coordination polymers [134-143]. Their synthetic strategy is to react $\left[\mathrm{Cu}\left(\mathrm{S}_{2} \mathrm{CNR}_{2}\right)_{2}\right]$ with $\left[\mathrm{CuBr}\left(\mathrm{SMe}_{2}\right)\right]$ in mixed organic solvents, with crystals forming upon concentration of the filtrate. The precise nature of the coordination polymer generated depends upon the dithiocarbamate substituents, with those derived from cyclic amines as the favoured species. In all the $\mathrm{Cu}(\mathrm{II})$, centres are bound by two dithiocarbamates in a square planar arrangement, and thus these polymers differ primarily in the nature of the $\mathrm{Cu}(\mathrm{I})$ halide sub-units and also how they arrange themselves with respect to the $\mathrm{Cu}$ (II) centres. Aspects of this work have been reviewed by Batten [144] and the only key examples will be given here. Thus, with $\left[\mathrm{Cu}\left\{\mathrm{S}_{2} \mathrm{CN}\left(\mathrm{CH}_{2}\right)_{n}\right\}_{2}\right](n=5,6)[136,139], 1 \mathrm{D}$ chains result (Figure 18b) in which $\mathrm{Cu}_{2} \mathrm{Br}_{4}$ sub-units link together the $\mathrm{Cu}$ (II) bis(dithiocarbamate) centres in the same way as previously reported by Golding and co-workers $(n=4)$ [68]. With the pyrrolidine dithiocarbamate complex $(n=4), \mathrm{Cu}_{6}$ sub-units result, formed via the linking of two crystallographically inequivalent $\mathrm{Cu}$ (II) bis(dithiocarbamate) centres linked via two $\mathrm{CuBr}$ groups to give a 3D network (Figure 18c) [134]. Methyl-substitution of the rings can have a significant effect on the nature of the polymer produced. For example, with 3,5-dimethylpiperidine dithiocarbamate, a 2D structure results via linking together $\mathrm{Cu}$ (II) centres with $\mathrm{Cu}_{3} \mathrm{Br}_{3}$ sub-units (Figure 18d) [138]. Related iodide-containing coordination polymers can also be prepared $[139,141]$ and they show similar structures to the bromides. 

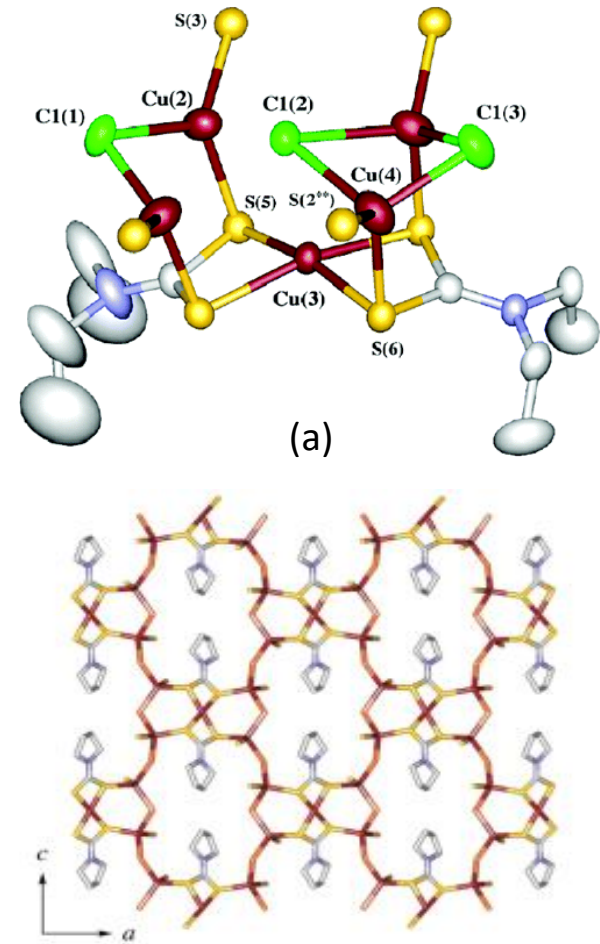

(c)

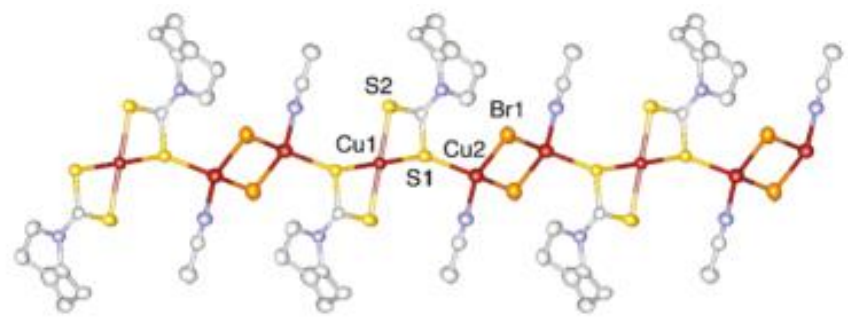

(b)

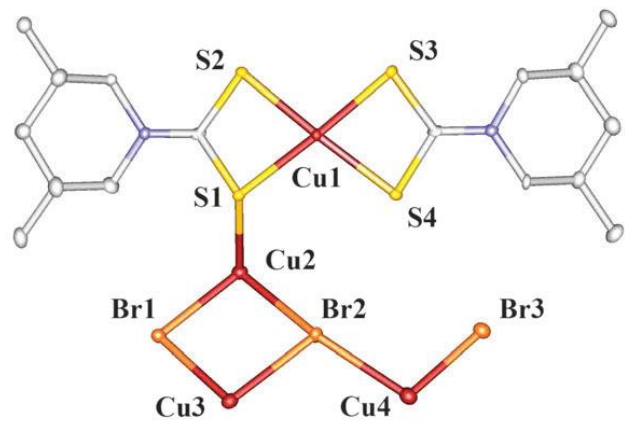

(d)

Figure 18. Representations of the molecular structures of $(\mathbf{a})$ the cation in $\left[\mathrm{Cu}_{5}\left(\mathrm{~S}_{2} \mathrm{CNEt}_{2}\right)_{2} \mathrm{Cl}_{3}\right]\left[\mathrm{FeCl}_{4}\right]$, (b) the 1D coordination polymer $\left[\mathrm{Cu}\left\{\mathrm{S}_{2} \mathrm{CN}\left(\mathrm{CH}_{2}\right)_{6}\right\}_{2} \cdot \mathrm{Cu}_{2} \mathrm{Br}_{4}\right]$, (c) the 3D structure of coordination polymer $\left[\mathrm{Cu}\left\{\mathrm{S}_{2} \mathrm{CN}\left(\mathrm{CH}_{2}\right)_{4}\right\}_{2} \cdot \mathrm{Cu}_{2} \mathrm{Br}_{4}\right]$ and $(\mathbf{d})$ the molecular sub-unit on $\left[\mathrm{Cu}\left\{\mathrm{S}_{2} \mathrm{CN}\left(\mathrm{CH}_{2}\right)_{3}(\mathrm{CHMe})_{2}\right\}_{2} \cdot \mathrm{Cu}_{3} \mathrm{Br}_{3}\right]$. $(\mathbf{a}, \mathbf{b})$ Reproduced with permission from $[133,136]$. Copyright 2005 and 2010 American Chemical Society. (c,d) Reproduced with permission from [134,138] Copyright 2011 and 2013 The Royal Society of Chemistry.

Mixed-valence $\mathrm{Cu}(\mathrm{I})-\mathrm{Cu}(\mathrm{II})$ dithiocarbamate coordination polymers have interesting physical properties, primarily stemming from their relatively small band gap, which results from the HOMOs of their various components. For example, while the band gap in $\left[\mathrm{Cu}\left(\mathrm{S}_{2} \mathrm{CN}-2,6-\mathrm{Me}_{2} \mathrm{C}_{5} \mathrm{H}_{8}\right)_{2}\right]$ is $1.30 \mathrm{eV}$, the coordination polymer generated upon the addition of [CuBr$\left.\left(\mathrm{SMe}_{2}\right)\right]$ has a band gap of only $1.04 \mathrm{eV}$ [143] and exhibits semi-conducting behaviour. The estimated bulk conductivity at $300 \mathrm{~K}$ of $1.4 \times 10^{-8} \mathrm{~S} \mathrm{~cm}^{-1}$ is similar to those with other dithiocarbamate ligands, which can be as high as $5.2 \times 10^{-7} \mathrm{~S} \mathrm{~cm}^{-1}$ [134].

A number of mixed-valence $\mathrm{Cu}(\mathrm{II})-\mathrm{Cu}$ (III) dithiocarbamate complexes are known, falling into a number of different types. They were first reported in the 1970s upon oxidation of $\mathrm{Cu}$ (II) bis(dithiocarbamate) complexes with halides or metal salts [145-147]. For example, Cras and Willemse prepared mixed-valence complexes $\left[\mathrm{Cu}_{3}\left(\mathrm{~S}_{2} \mathrm{CNBu}_{2}\right)_{6}\right][\mathrm{X}]$ $\left(\mathrm{X}=\mathrm{M}_{2} \mathrm{Br}_{6} ; \mathrm{M}=\mathrm{Zn}, \mathrm{Cd}, \mathrm{Hg}\right)$ upon the addition of $\mathrm{MBr}_{2}$ to $\left[\mathrm{Cu}\left(\mathrm{S}_{2} \mathrm{CNBu}_{2}\right)_{2}\right.$ ] [145], a complex disproportionation and dithiocarbamate redistribution reaction, which also afforded $\left[\mathrm{Zn}\left(\mathrm{S}_{2} \mathrm{CNBu}_{2}\right)_{2}\right],\left[\mathrm{Cu}\left(\mathrm{S}_{2} \mathrm{CNBu}_{2}\right)_{2}\right]\left[\mathrm{ZnCl}_{3}\right]$ and a (purported) nonanuclear $\mathrm{Cu}(\mathrm{I})$ cluster, most likely being $\left[\left\{\mathrm{Cu}\left(\mu_{4}-\mathrm{S}_{2} \mathrm{CNBu}_{2}\right)\right\}_{8}\right]^{2+}[100]$. They are coordination polymers consisting of $\left[\mathrm{Cu}_{3}\left(\mathrm{~S}_{2} \mathrm{CNR}_{2}\right)_{6}\right][\mathrm{X}]_{2}$ sub-units, precise structures that are dependent upon the nature of both $\mathrm{R}$ and $\mathrm{X}[145,146]$. For example, $\left[\mathrm{Cu}_{3}\left(\mathrm{~S}_{2} \mathrm{CNEt}_{2}\right)_{6}\right][\mathrm{Br}]_{2}$, contains stacked $\mathrm{Cu}\left(\mathrm{S}_{2} \mathrm{CNEt}_{2}\right)_{2}$ and $\mathrm{Cu}\left(\mathrm{S}_{2} \mathrm{CNEt}_{2}\right) \mathrm{Br}_{2}$ units with both copper centres adopting a distorted octahedral coordination. An analysis of $\mathrm{Cu}-\mathrm{S}$ distances suggests that it is best considered as being composed of $\left[\mathrm{Cu}\left(\mathrm{S}_{2} \mathrm{CNEt}_{2}\right)_{2}\right]^{+}$and $\left[\mathrm{Cu}\left(\mathrm{S}_{2} \mathrm{CNEt}_{2}\right) \mathrm{Br}_{2}\right]^{-}$ions containing $\mathrm{Cu}(\mathrm{III})$ and $\mathrm{Cu}(\mathrm{II})$ centres, respectively [146]. Crystal structures of $\left[\mathrm{Cu}_{3}\left(\mathrm{~S}_{2} \mathrm{CNBu}_{2}\right)_{6}\right][\mathrm{X}]_{2}\left(\mathrm{X}=\mathrm{CdBr}_{3}, \mathrm{HgBr}_{3}\right)[145,148]$ show a centrosymmetric $\mathrm{Cu}_{3}$ unit in which $\left[\mathrm{Cu}\left(\mathrm{S}_{2} \mathrm{CNBu}_{2}\right)_{2}\right]$ is sandwiched between two $\mathrm{Cu}(\mathrm{III})\left[\mathrm{Cu}\left(\mathrm{S}_{2} \mathrm{CNBu}_{2}\right)_{2}\right]^{+}$sub-units and the $\left[\mathrm{M}_{2} \mathrm{Br}_{6}\right]^{2-}$ counter ions are non-coordinating. Stacking of $\mathrm{Cu}(\mathrm{II})$ and $\mathrm{Cu}(\mathrm{III})$ units can be extended, with the addition of $\left[\mathrm{Cu}\left(\mathrm{ClO}_{4}\right)_{2}\right]$ to $\left[\mathrm{Cu}\left(\mathrm{S}_{2} \mathrm{CNPr}\right)_{2}\right]_{2}$ in $\mathrm{CHCl}_{3}$ resulting in the formation of the dark green coordination 
polymer $\left[\mathrm{Cu}\left(\mathrm{S}_{2} \mathrm{CNPr}_{2}\right)_{2}\right]_{2}\left[\mathrm{ClO}_{4}\right]$. This polymeric complex consists of a chain of alternating $\mathrm{Cu}(\mathrm{II})$ and $\mathrm{Cu}(\mathrm{III})$ centres held together by intermolecular $\mathrm{Cu}-\mathrm{S}$ interactions (Figure 19a), while the perchlorate anions are not metal coordinated [149]. The formation of this mixedvalence polymer presumably results from the initial generation of $\left[\mathrm{Cu}\left(\mathrm{S}_{2} \mathrm{CNPr}_{2}\right)_{2}\right]\left[\mathrm{ClO}_{4}\right]$, which co-crystallises with unreacted $\left[\mathrm{Cu}\left(\mathrm{S}_{2} \mathrm{CNPr}_{2}\right)_{2}\right]_{2}$.

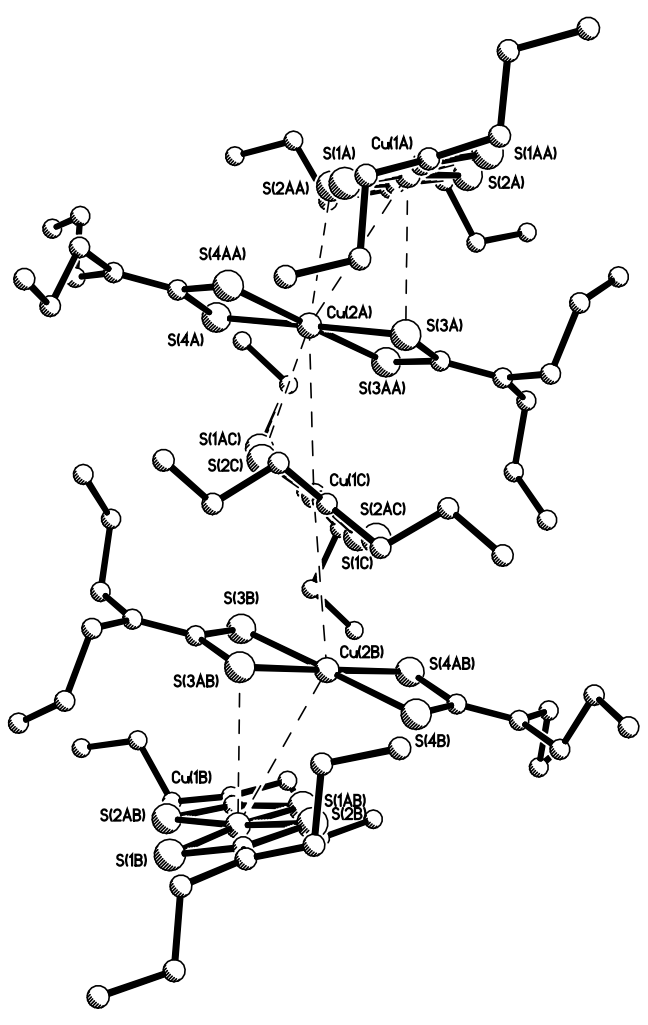

(a)
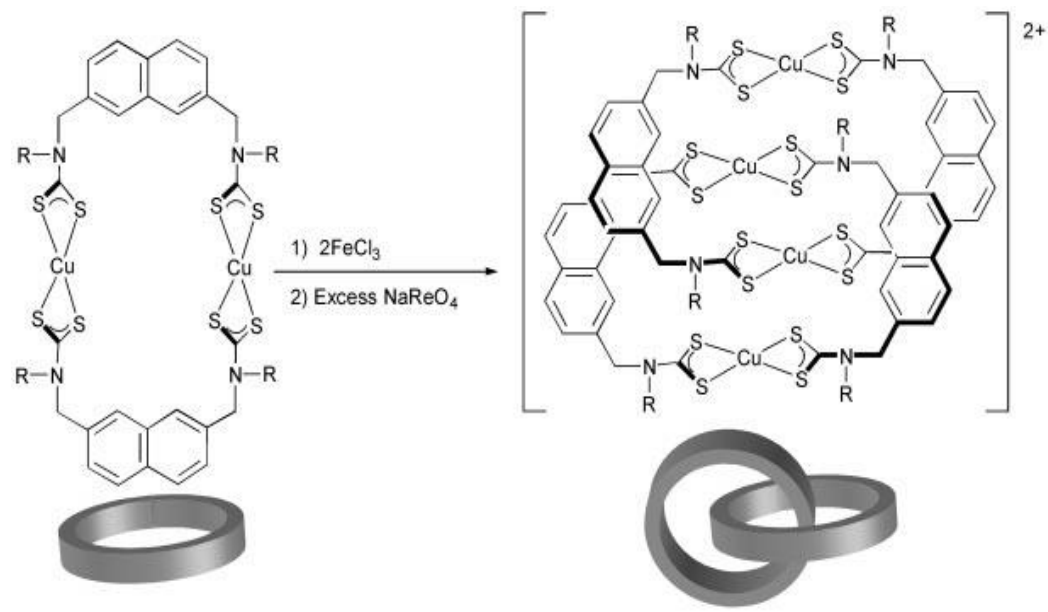

(b)

Figure 19. (a) The molecular structure of mixed-valence $\left[\mathrm{Cu}\left(\mathrm{S}_{2} \mathrm{CNPr}_{2}\right)_{2}\right]_{2}\left[\mathrm{ClO}_{4}\right]$, and (b) the formation and structure of mixed-valence catenane complexes reported by Beer with interlocking $\mathrm{Cu}(\mathrm{II})$ and $\mathrm{Cu}(\mathrm{III})$ rings. Reproduced with permission from [149,150]. Copyright 2013 Elsevier and 2001 John Wiley and Sons.

A quite different type of mixed-valence $\mathrm{Cu}(\mathrm{II})-\mathrm{Cu}$ (III) dithiocarbamates are the catenane complexes reported by Beer, which consist of interlocking $\mathrm{Cu}$ (II) and $\mathrm{Cu}$ (III) rings (Figure 19b) [150]. While there is disorder between the $\mathrm{Cu}$ (II) and $\mathrm{Cu}(\mathrm{III})$ centres in the solid-state, magnetic susceptibility and electrochemical measurements suggest that the tetranuclear catenane dications consist of alternating $\mathrm{Cu}(\mathrm{II}) \mathrm{Cu}(\mathrm{III}) \mathrm{Cu}(\mathrm{II}) \mathrm{Cu}(\mathrm{III})$ centres.

There is one example of a coordination dithiocarbamate complex containing $\mathrm{Cu}(\mathrm{I})$, $\mathrm{Cu}(\mathrm{II})$ and $\mathrm{Cu}$ (III) centres [151]. Octanuclear $\left[\mathrm{Cu}_{8} \mathrm{Br}_{7}\left(\mathrm{~S}_{2} \mathrm{CNC}_{6} \mathrm{H}_{12}\right)_{4}\right]$ (Figure 20) results from the addition of $\mathrm{CuBr}_{2}$ and $\mathrm{Br}_{2}$ to $\left[\mathrm{Cu}\left(\mathrm{S}_{2} \mathrm{CNC}_{6} \mathrm{H}_{12}\right)_{2}\right]$ in $\mathrm{CHCl}_{3}$ and consists of two $\mathrm{Cu}$ bis(dithiocarbamate) subunits linked via a $\mathrm{Cu}_{6} \mathrm{Br}_{6}$ moiety, with a further bromide ion encapsulated within this sub-cluster. Inspection of the $\mathrm{Cu}-\mathrm{S}$ distances shows that one is a Cu(II) [Cu-S(av) $2.3106 \AA]$ and the second a Cu(III) [Cu-S(av) $2.2186 \AA$ ] centre. It is supported by a magnetic susceptibility of $1.49 \mu_{\mathrm{B}}$ at $300 \mathrm{~K}$, consistent with one unpaired electron. Individual octanuclear clusters align head-to-tail via weak intermolecular interactions to generate a 1D coordination polymer. In the UV-visible spectrum, a broad absorption band at $1400 \mathrm{~nm}$ is attributed to inter-valence charge transfer from the $\mathrm{Cu}$ (II) to $\mathrm{Cu}(\mathrm{III})$ centre through the weak $\mathrm{Cu}-\mathrm{S}$ bonds. 


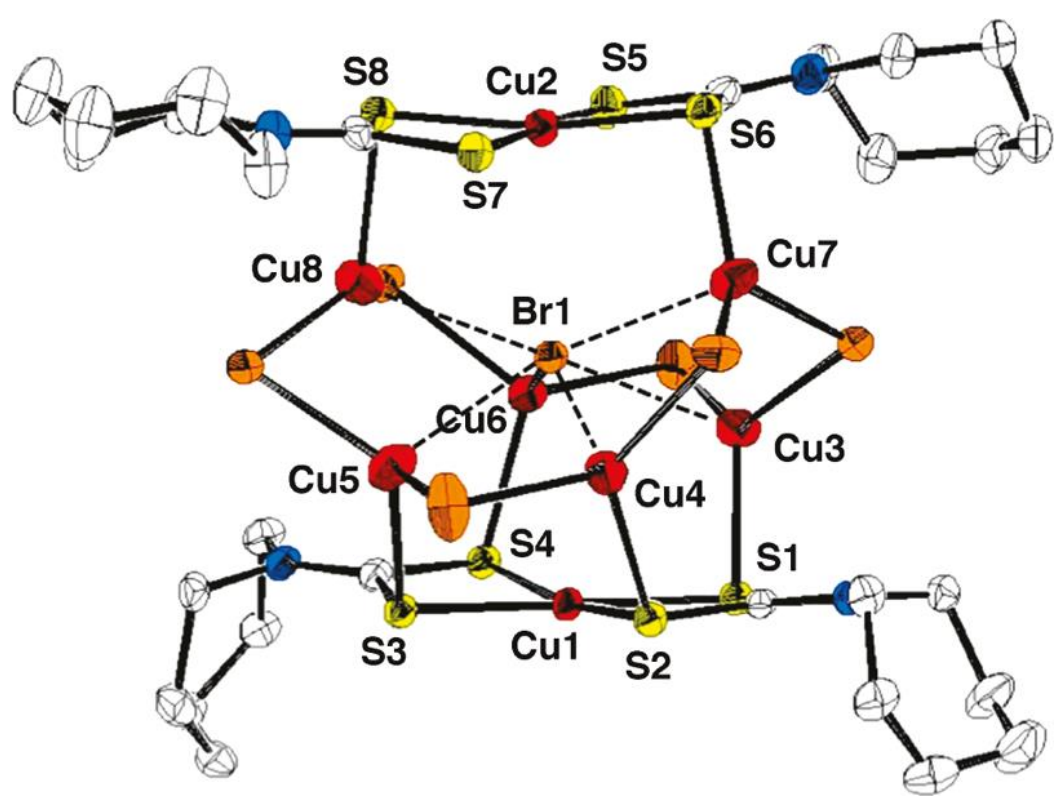

Figure 20. The molecular structure of $\left[\mathrm{Cu}_{8} \mathrm{Br}_{7}\left(\mathrm{~S}_{2} \mathrm{CNC}_{6} \mathrm{H}_{12}\right)_{4}\right]$. Reproduced with permission from [151]. Copyright 2011 American Chemical Society.

\section{Other Copper Dithiocarbamate Complexes}

There are a small number of complexes that contain the copper dithiocarbamate group that have not been covered above. While at first sight it might seem surprising that simple mixed-ligand complexes of the type $\left[\mathrm{Cu}\left(\mathrm{S}_{2} \mathrm{CNR}_{2}\right)\right.$ (anionic-chelate) $]$ are not known, this likely relates to the lability of the dithiocarbamate at the $\mathrm{Cu}(\mathrm{II})$ centre. For example, an obvious candidate would be $\left[\mathrm{Cu}\left(\mathrm{S}_{2} \mathrm{CNEt}_{2}\right)(\mathrm{acac})\right]$, which, while being briefly mentioned in the literature, full characterisation data are always missing. Indeed, while it is suggested to result, along with $\left[\mathrm{Cu}(\mathrm{acac})_{2}\left(\mathrm{~S}_{2} \mathrm{CNEt}_{2}\right)\right]$, from the addition of $\left[\mathrm{Cu}(\mathrm{acac})_{2}\right]$ to $\mathrm{R}_{-} \mathrm{S}_{2} \mathrm{CNEt}_{2}$ in reversible-reactivation radical polymerisation reactions [152], the authors could find no evidence for such species in the reactions of $\left[\mathrm{Cu}(\mathrm{acac})_{2}\right]$ with tetramethyl thiuram disulfide. The mixed-ligand $\mathrm{Cu}(\mathrm{I})$ complex $\left[\mathrm{Cu}\left(\mathrm{\kappa}_{1}-\mathrm{S}_{2} \mathrm{CNC}_{4} \mathrm{H}_{8}\right)\left(\mathrm{\kappa}_{2}-\mathrm{SeS}_{2} \mathrm{CNC}_{4} \mathrm{H}_{8}\right)\right]\left[\mathrm{PPh}_{4}\right]$ is an unexpected products of the reaction of $\left[\mathrm{Cu}\left(\mathrm{S}_{2} \mathrm{CNC}_{4} \mathrm{H}_{8}\right)_{2}\right]$ with $\left[\mathrm{WSe}_{4}\right]\left[\mathrm{PPh}_{4}\right]_{2}$ [153]. It formally results from the insertion of selenium into one of the $\mathrm{Cu}-\mathrm{S}$ bonds, but this is coupled with electron-transfer and the dithiocarbamate is monodentate. This is surprising as insertion of the isoelectronic NTos group affords $\mathrm{Cu}$ (II) complexes [74,75].

As far as we are aware, the only well-characterised examples of mixed-ligand $\mathrm{Cu}(\mathrm{II})$ dithiocarbamate complexes are 5-coordinate species containing the unsaturated dinitrogen ligands, 2,2'-bipy or 1,10-phen [154-157], an example being [CuI $\left(\mathrm{S}_{2} \mathrm{CNMe}_{2}\right)\left(2,2^{\prime}\right.$-bipy $\left.)\right]$ (Figure 21a) [154]. Synthetic methods are not always clear as much of this work has appeared in crystallography journals, but $\left[\mathrm{CuI}\left(\mathrm{S}_{2} \mathrm{CNMe}_{2}\right)\left(2,2^{\prime}\right.\right.$-bipy $\left.)\right]$ is prepared by the co-addition of $\mathrm{NaS}_{2} \mathrm{CNMe}_{2}$ and 2,2'-bipy to $\left[\mathrm{Cu}(\mathrm{OAc})_{2}\right]$ in the presence of NaI. All contain a distorted square pyramidal centre with the halide (normally iodide) in the apical position. An unusual variation of this structural motif is $\mathrm{PbI}_{4}\left[\mathrm{Cu}\left(\mathrm{S}_{2} \mathrm{CNMe}\right) \text { (bipy) }\right]_{2}$ formed in low yields upon the addition of $\mathrm{PbI}_{2}, \mathrm{NaS}_{2} \mathrm{CNMe}_{2}$ and 2,2'-bipy to $\mathrm{Cu}(\mathrm{OAc})_{2}$ in DMF [158]. Here, two $\left[\mathrm{CuI}\left(\mathrm{S}_{2} \mathrm{CNMe}_{2}\right)\left(2,2^{\prime}\right.\right.$-bipy $\left.)\right]$ sub-units are formally linked via a linear $\mathrm{PbI}_{2}$ moiety (Figure 21b). 


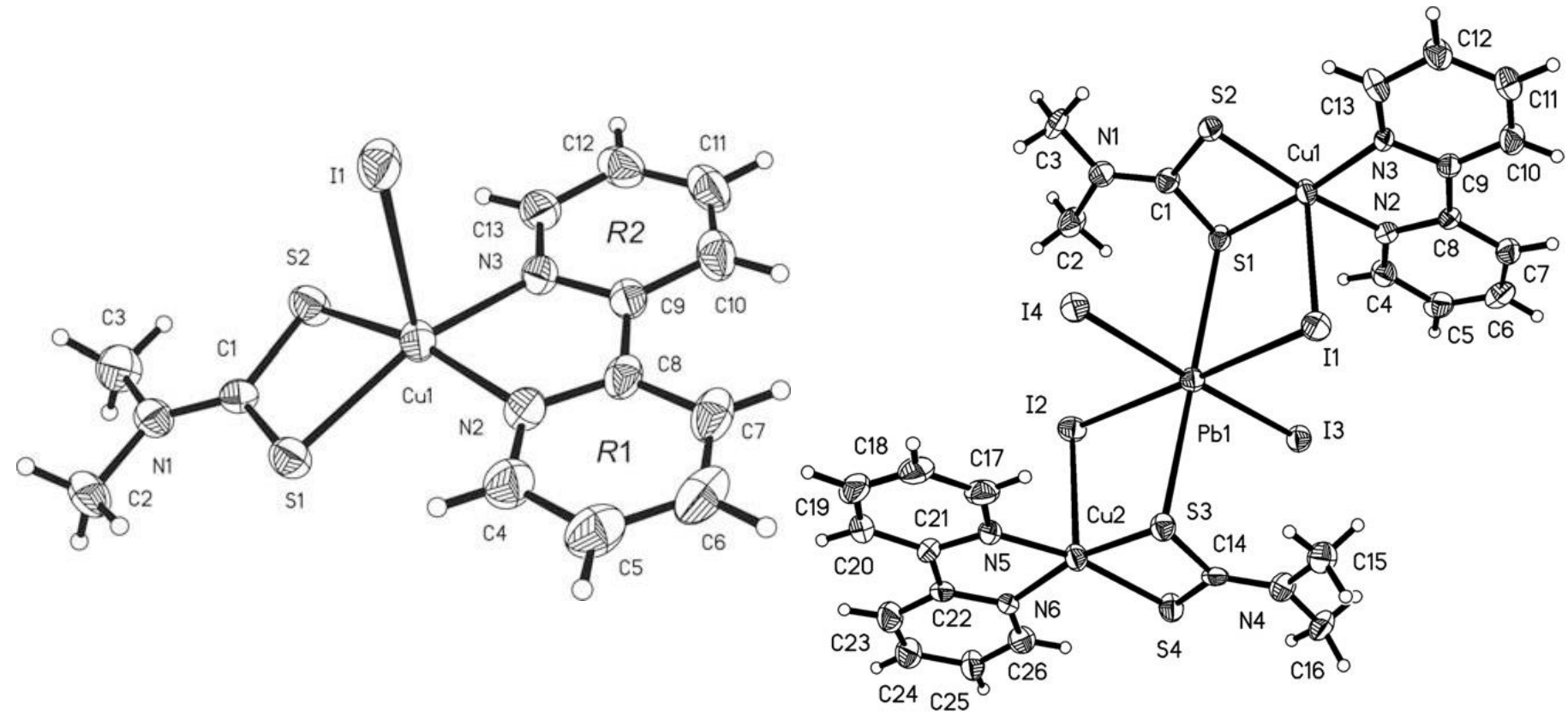

(a)

(b)

Figure 21. The molecular structures of (a) $\left[\mathrm{CuI}\left(\mathrm{S}_{2} \mathrm{CNMe}_{2}\right)\left(2,2^{\prime}\right.\right.$-bipy) $]$ and $(\mathbf{b}) \mathrm{PbI}_{4}\left[\mathrm{Cu}\left(\mathrm{S}_{2} \mathrm{CNMe}\right)(\text { bipy })\right]_{2}$. Reproduced with permission from [154]. Copyright 1997 De Gruyter and from [158].

A second group of complexes are sulfide- or selenide-bridged clusters of either vanadium $[159,160]$ or molybdenum-tungsten [161-165], which incorporate between one and four $\mathrm{Cu}(\mathrm{II})$ dithiocarbamate moieties. The group 6 clusters result upon the addition of $\left[\mathrm{ME}_{4}\right]^{2-}(\mathrm{E}=\mathrm{S}, \mathrm{Se} ; \mathrm{M}=\mathrm{Mo}, \mathrm{W})$ to $\mathrm{CuX}$ in the presence of dithiocarbamate salts, with the precise cluster generated being dependent upon the ratio of metal ions. For example, with $\left[\mathrm{MoS}_{4}\right]^{2-}$ and $\mathrm{CuCl}$ in a ca.1:2 ratio and a slight excess of $\mathrm{NaS}_{2} \mathrm{CNMe}_{2}$, trinuclear $\left[\mathrm{MoCu}_{2}(\mu-\mathrm{S})_{4}\left(\mathrm{~S}_{2} \mathrm{CNMe}_{2}\right)_{2}\right]^{2-}$ results (Figure 22a) [165]. These reactions have been shown to proceed via the initial formation of copper halide clusters, with later substitution of the halide for the chelating dithiocarbamate as shown in the synthesis of pentanuclear $\left[\mathrm{WCu}_{4}\left(\mu_{3}-\mathrm{Se}\right)_{4}\left(\mathrm{~S}_{2} \mathrm{CNEt}_{4}\right)_{4}\right]^{2-}$ (Figure 22b) [163]. In the solid state, the geometry around the copper centre is a highly distorted tetrahedron, consistent with $\mathrm{Cu}(\mathrm{I})$ centres. Electrochemical measurements also support this assignment with tetranuclear $\left[\mathrm{MoCu}_{3}(\mu-\right.$ S) $\left.{ }_{4}\left(\mathrm{~S}_{2} \mathrm{CNMe}\right)_{3}\right]^{2-}$ showing two quasi-reversible oxidations in MeCN [165]. There is one example of a higher nuclearity cluster being generated from these reactions, namely $\left[\mathrm{Mo}_{2} \mathrm{Cu}_{5} \mathrm{~S}_{2}\left(\mu_{3}-\mathrm{S}\right)_{6}\left(\mathrm{~S}_{2} \mathrm{CNMe}_{2}\right)_{3}\right]^{2-}$ [166]. It has a fused defective cubane skeleton and can be envisaged as consisting of two $\mathrm{MoCu}_{2} \mathrm{~S}\left(\mu_{3}-\mathrm{S}\right)_{3}$ linked by a shared copper atom. Two of the dithiocarbamates bridge the copper centres while the third is chelating.

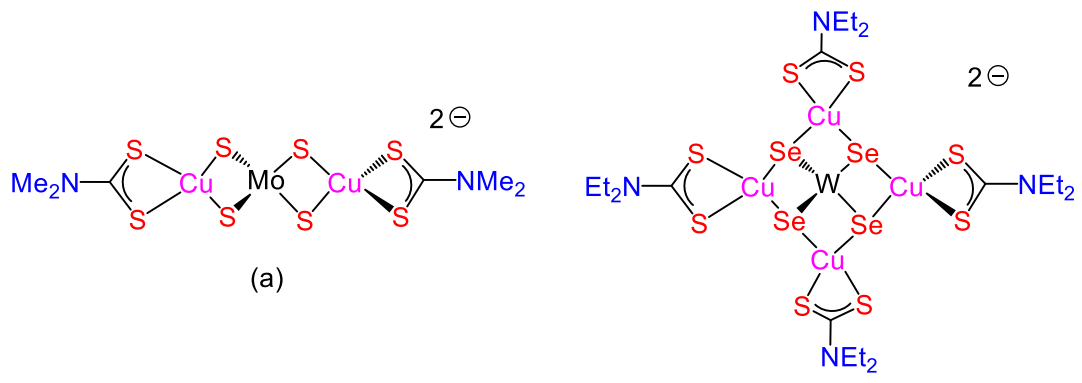

(b)

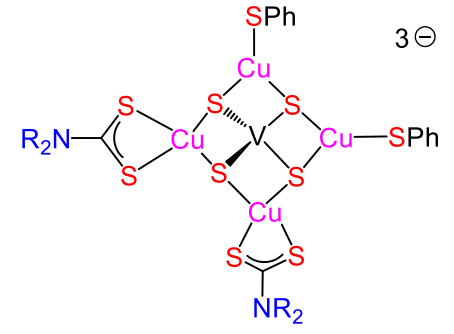

(c)

Figure 22. Line drawings of heteronuclear clusters $(\mathbf{a}-\mathbf{c})$ formed upon addition of $\left[\mathrm{ME}_{4}\right]^{2-}(\mathrm{M}=\mathrm{Mo}, \mathrm{W} ; \mathrm{E}=\mathrm{S}, \mathrm{Se})$ to $\mathrm{CuX}$ in the presence of dithiocarbamate and thiolate ligands. 
Similar reactions with $\left[\mathrm{VS}_{4}\right]^{3-}$ lead to theformation of $\left[\mathrm{Cu}\left(\mathrm{S}_{2} \mathrm{CNR}_{2}\right)_{2}\right]$ resulting from oxidation of the $\mathrm{Cu}(\mathrm{I})$ centre, attributed to the higher oxidative ability of $\left[\mathrm{VS}_{4}\right]^{3-}$ as compared to $\left[\mathrm{MS}_{4}\right]^{2-}(\mathrm{M}=\mathrm{Mo}, \mathrm{W})$. The addition of $\mathrm{NaSPh}$ to the mixture allows for the isolation of a range of mixed dithiocarbamate-thiophenolate such as $\left[\mathrm{VCu}_{4}(\mu-\mathrm{S})_{4}(\mathrm{SPh})_{2}\left(\mathrm{~S}_{2} \mathrm{CNR}_{2}\right)_{2}\right]^{3-}$ (Figure 22c), proposed to result from the concurrent addition of $\mathrm{Cu}(\mathrm{SPh})$ and $\mathrm{Cu}\left(\mathrm{S}_{2} \mathrm{CNR}_{2}\right)$ fragments to $\left[\mathrm{VS}_{4}\right]^{3-}[160]$. The solid-state structures closely resemble those of the group 6 clusters, but in solution, there is evidence of the disproportionation of $\left[\mathrm{VCu}_{4}(\mu-\mathrm{S})_{4}(\mathrm{SPh})_{4-n}\left(\mathrm{~S}_{2} \mathrm{CNR}_{2}\right)_{n}\right]^{3-}(n=1,2)$, and electrochemistry shows only irreversible redox behaviour.

\section{Applications as Single-Source Precursors (SSPs) to Semi-Conducting Nanomaterials}

Many methods have been explored for the preparation of nanoscale copper sulfides, and the thermal decomposition of copper-dithiocarbamate single-source precursors (SSPs) via cleavage of relatively weak $\mathrm{C}-\mathrm{S}$ bonds provides a simple and tuneable route to pure phase materials of different stoichiometries and morphologies [167]. In addition, dithiocarbamates themselves can act as capping agents, thus providing a physical barrier between interparticle interactions, thereby preventing agglomeration, which are particularly important as the nanoscopic properties of materials are optimised [168]. The thermal behaviour of copper dithiocarbamates is dependent on the reaction environment. Under nitrogen, it proceeds via dithiocarbamate loss to give copper sulfide residues, while in air, nonstoichiometric oxygen uptake leads to the formation of copper oxide(s). Oxidation of sulfur-containing species has also been identified at higher temperatures, resulting in the formation of sulfide, with subsequent oxidation to sulfate being followed by decomposition of the sulfate to oxide [169]. Copper dithiocarbamates have, therefore, been extensively utilised in the synthesis of both binary and ternary copper sulfides under inert atmosphere.

\subsection{Binary Copper Sulfides}

Copper sulfides are widely studied as a result of their application in areas such as optical filters, solar cells, photovoltaics, optical imaging and super-ionic materials [170]. They exist in a variety of stoichiometric phases ranging from copper-rich $\left(\mathrm{Cu}_{2} \mathrm{~S}\right)$ to sulfur-rich (CuS) phases, with a phase-dependent direct/indirect bandgap in the range of 1.1-2.0 eV. Some stoichiometric-dependent properties of $\mathrm{Cu}_{2-x} \mathrm{~S}$ include plasmonic absorption, observed in the non-stoichiometric phases around the IR region, and electrical conductivity, which decreases from copper-poor to copper-rich stoichiometries [171]. These wide variations in optical and electrical properties also account for the versatility of $\mathrm{Cu}_{2-x} \mathrm{~S}$ in different applications. The use of copper dithiocarbamates as SSPs for the synthesis of $\mathrm{Cu}_{2-x} \mathrm{~S}$ offers a simple and tuneable route to the synthesis of various stoichiometries through the choice of metal complex and reaction system.

There are a number of deposition strategies, the simplest being the heating of the SSP in the solid state. $\left[\mathrm{Cu}\left(\mathrm{S}_{2} \mathrm{CNEt}_{2}\right)_{2}\right]$ melts at ca. $200{ }^{\circ} \mathrm{C}$ and decomposes at $230-300{ }^{\circ} \mathrm{C}$ [63], and upon increasing the length of the alkyl chain, some small changes in volatility result [7]. Introduction of fluorine, as in $\left[\mathrm{Cu}\left(\mathrm{S}_{2} \mathrm{CN}\left(\mathrm{CH}_{2} \mathrm{CF}_{3}\right)_{2}\right)\right]$, significantly reduces the decomposition temperature to $130{ }^{\circ} \mathrm{C}$ and this SSP has been used to deposit high-quality, phase-pure, chalcocite films [172]. For thermal decomposition of the solids, the sulfide product has been reported to depend upon the nature of substituents, but most likely it is the temperature that is the key differentiator. For example, decomposition of $\left[\mathrm{Cu}\left(\mathrm{S}_{2} \mathrm{CNOct}_{2}\right)_{2}\right]$ at $130{ }^{\circ} \mathrm{C}$ affords $\mathrm{CuS}$, but at $220^{\circ} \mathrm{C}$ pure $\mathrm{Cu}_{1.8} \mathrm{~S}$ results, highlighting the reduction of $\mathrm{Cu}$ (II) at temperatures above $200{ }^{\circ} \mathrm{C}$ [173]. Interestingly, when the SSP is damp, microspheres of $\mathrm{CuS}$ result at $180^{\circ} \mathrm{C}$, being rationalised by the co-evaporation of water, which creates the central cavities around which the CUS nucleates. The SSP can also be pre-dissolved in a coordinating solvent and then deposited from this solution. Using this approach, trioctylphosphine (TOP) solutions of $\left[\mathrm{Cu}\left(\mathrm{S}_{2} \mathrm{CNEt}_{2}\right)_{2}\right]$, when heated $\mathrm{TO} 240-250{ }^{\circ} \mathrm{C}$, deposited hexagonal nano-barrels of $\mathrm{Cu}_{2} \mathrm{~S}$ (chalcocite) onto $\mathrm{Si}(100)$ substrates [174]. Interestingly, they found that the morphology of the nanomaterials could be changed to nanowires, upon first 
sequentially depositing layers of chromium $(2 \mathrm{~nm})$ and bismuth $(12 \mathrm{~nm})$ onto the $\operatorname{Si}(100)$ substrate, and then decomposing the TOP solution of $\left[\mathrm{Cu}\left(\mathrm{S}_{2} \mathrm{CNEt}_{2}\right)_{2}\right]$ at $250{ }^{\circ} \mathrm{C}$.

Copper sulfide materials with small dimensions show quantum dot (QD) behaviour, which makes them attractive materials for a range of imaging techniques. Burda and co-workers have reported that decomposition of $\left[\mathrm{Cu}\left(\mathrm{S}_{2} \mathrm{CNEt}_{2}\right)_{2}\right]$ (in the presence of added sulfur) in a trioctylphosphine (TOP)/TOPO mixture at $250{ }^{\circ} \mathrm{C}$ gives $\mathrm{Cu}_{1.8} \mathrm{~S}$ QDs with a band gap of $2.35 \mathrm{eV}$, being significantly blue-shifted with respect to the bulk material [175]. The size and shape of these nanomaterials were not given, but Qian and co-workers later reported that a similar decomposition of $\left[\mathrm{Cu}\left(\mu^{3}-\mathrm{S}_{2} \mathrm{CNEt}_{2}\right)\right]_{4}$, at $110{ }^{\circ} \mathrm{C}$ for $12 \mathrm{~h}$ in a mixture of oleylamine (OLA) and dodecanethiol (DDT), gave ultra-thin nanowires of chalcocite [176]. By controlling the decomposition conditions (temperature and solvent ratios) they were able to generate nanowires with diameters ranging from $1.7 \mathrm{~nm}$ to tens of micro-meters, being aligned in bundles. Alivisatos and co-workers also developed this method forming $\left[\mathrm{Cu}\left(\mu^{3}-\mathrm{S}_{2} \mathrm{CNEt}_{2}\right)\right]_{4}$ in situ in OLA/DDT at $180{ }^{\circ} \mathrm{C}$ to generate hexagonal nanocrystals of chalcocite of $5.4( \pm 0.4) \mathrm{nm}$ [177]. Further, by varying the copper to ligand ratio they were able to produce mono-disperse $\mathrm{Cu}_{1.93} \mathrm{~S}$ QDs with sizes ranging 2.5-6 nm [178].

In order to improve the biocompatibility of copper sulfide materials, water-soluble dithiocarbamate complexes with moieties capable of acting as capping agents for the prepared nanoparticles have been explored. These complexes could be thermolysed hydrothermally at relatively low temperature and without employing any organic passivating agent. In this way, thermolysis of $\left[\mathrm{Cu}\left\{\mathrm{S}_{2} \mathrm{CN}\left(\mathrm{CH}_{2} \mathrm{OH}\right)_{2}\right\}_{2}\right]$ in water at $90{ }^{\circ} \mathrm{C}$ produces $\mathrm{CuS}$ nanospheres with a diameter of $8 \pm 1 \mathrm{~nm}$, showing a surface plasmon resonance at ca. $990 \mathrm{~nm}$ [31], and to demonstrate their potential therapeutic utility, their photothermal effect was measured using a $785 \mathrm{~nm}$ laser. An increase of $15.1^{\circ} \mathrm{C}$ over $3 \mathrm{~min}$ was found, but this led only to a $2 \%$ loss of cervical cancer (HeLa) cells being observed after $24 \mathrm{~h}$ exposure in water. Decomposition of $\left[\mathrm{Cu}\left(\mathrm{S}_{2} \mathrm{CNEt}_{2}\right)_{2}\right]$ in 6-amino caproic acid also gives water-soluble nanoparticles, but now of digenite phase $\left(\mathrm{Cu}_{9} \mathrm{~S}_{5}\right)$ [179], and irradiation with a $980 \mathrm{~nm}$ laser led to a temperature increase of $15.1^{\circ} \mathrm{C}$ in $7 \mathrm{~min}$. These nanomaterials have potential applications in photodynamic therapy, although for $\mathrm{Cu}_{9} \mathrm{~S}_{5}$ the photothermal conversion efficiency is likely too low.

High boiling primary amines, especially oleylamine (OLA, bp $364^{\circ} \mathrm{C}$ ), have been widely used as media in the decomposition of copper dithiocarbamates. This was first reported by $\mathrm{Hu}$ and co-workers who decomposed $\left[\mathrm{Cu}\left(\mathrm{S}_{2} \mathrm{CNEt}_{2}\right)_{2}\right]$ in OLA at $300{ }^{\circ} \mathrm{C}$, to generate OLA-capped $\mathrm{Cu}_{9} \mathrm{~S}_{5}$ nanocrystals with a diameter of ca. $70 \mathrm{~nm}$ and athickness of ca. $13 \mathrm{~nm}$ [179]. The phase is highly sensitive to the experimental conditions used and, thus, decomposition of the same SSP in OLA/oleic acid (OA) mixtures at $280{ }^{\circ} \mathrm{C}$ gives $\mathrm{Cu}_{7.2} \mathrm{~S}_{4}$ with a mean diameter of ca. $20 \mathrm{~nm}$ from the decomposition of [Cu( $\left.\left.\mathrm{S}_{2} \mathrm{CNEt}_{2}\right)_{2}\right]$ [180]. More recently, Botha and Ajibade [181] used the hot-injection method to decompose $\left[\mathrm{Cu}\left(\mathrm{S}_{2} \mathrm{CNC}_{5} \mathrm{H}_{10}\right)_{2}\right]$ in OLA and isolated pure phases of $\mathrm{CuS}$ and $\mathrm{Cu}_{9} \mathrm{~S}_{5}$ at 180 to $220^{\circ} \mathrm{C}$, respectively. CuS can also be obtained upon decomposing $\left[\mathrm{Cu}\left(\mathrm{S}_{2} \mathrm{CNC}_{4} \mathrm{H}_{8} \mathrm{X}\right)_{2}\right]$ in OLA $(X=\mathrm{NPh})$ [182] or octadecylamine $(X=\mathrm{S})$ [183], and Motaung et al. [184] reported the synthesis of $\mathrm{Cu}_{7} \mathrm{~S}_{4}$ upon thermolysis of $\left[\mathrm{Cu}\left(\mathrm{S}_{2} \mathrm{CNBuPh}\right)_{2}\right]$ in OLA. Wang and co-workers studied the decomposition of the longer-chain SSP, $\left[\mathrm{Cu}\left(\mathrm{S}_{2} \mathrm{CNBu}_{2}\right)_{2}\right]$, injecting it into a mixture of OLA and OD (2:3) with added DDT (0.8 equiv.) at $190{ }^{\circ} \mathrm{C}$ to afford $\mathrm{Cu}_{7} \mathrm{~S}_{4}$ nanocrystals with an average diameter of $9 \pm 1 \mathrm{~nm}$ [185].

Trindade and co-workers have decomposed both $\left[\mathrm{Cu}\left(\mathrm{S}_{2} \mathrm{CNEt}_{2}\right)_{2}\right]$ and $\left[\mathrm{Cu}\left(\mathrm{S}_{2} \mathrm{CNBu}_{2}\right)_{2}\right]$ at $240{ }^{\circ} \mathrm{C}$ in ionic liquids, obtaining digenite $\left(\mathrm{Cu}_{9} \mathrm{~S}_{5}\right)$ nanocrystals, as opposed to covellite, which was formed at the same temperature in OLA [186]. Solvothermal process was recently utilised to decompose $\left[\mathrm{Cu}\left(\mathrm{S}_{2} \mathrm{CNMePh}\right)_{2}\right]$ in OLA. At temperatures below $240{ }^{\circ} \mathrm{C}$, a mixture of $\mathrm{CuS}$ and $\mathrm{Cu}_{9} \mathrm{~S}_{5}$ resulted, but above $240{ }^{\circ} \mathrm{C}$ pure $\mathrm{Cu}_{9} \mathrm{~S}_{5}$ was formed (Figure 23). Oleylamine was used as the capping agent and the phase selectivity for the $\mathrm{Cu}_{9} \mathrm{~S}_{5}$ phase was attributed to its increased tendency, at high temperature, to drive the reaction towards the copper rich phase [187]. 


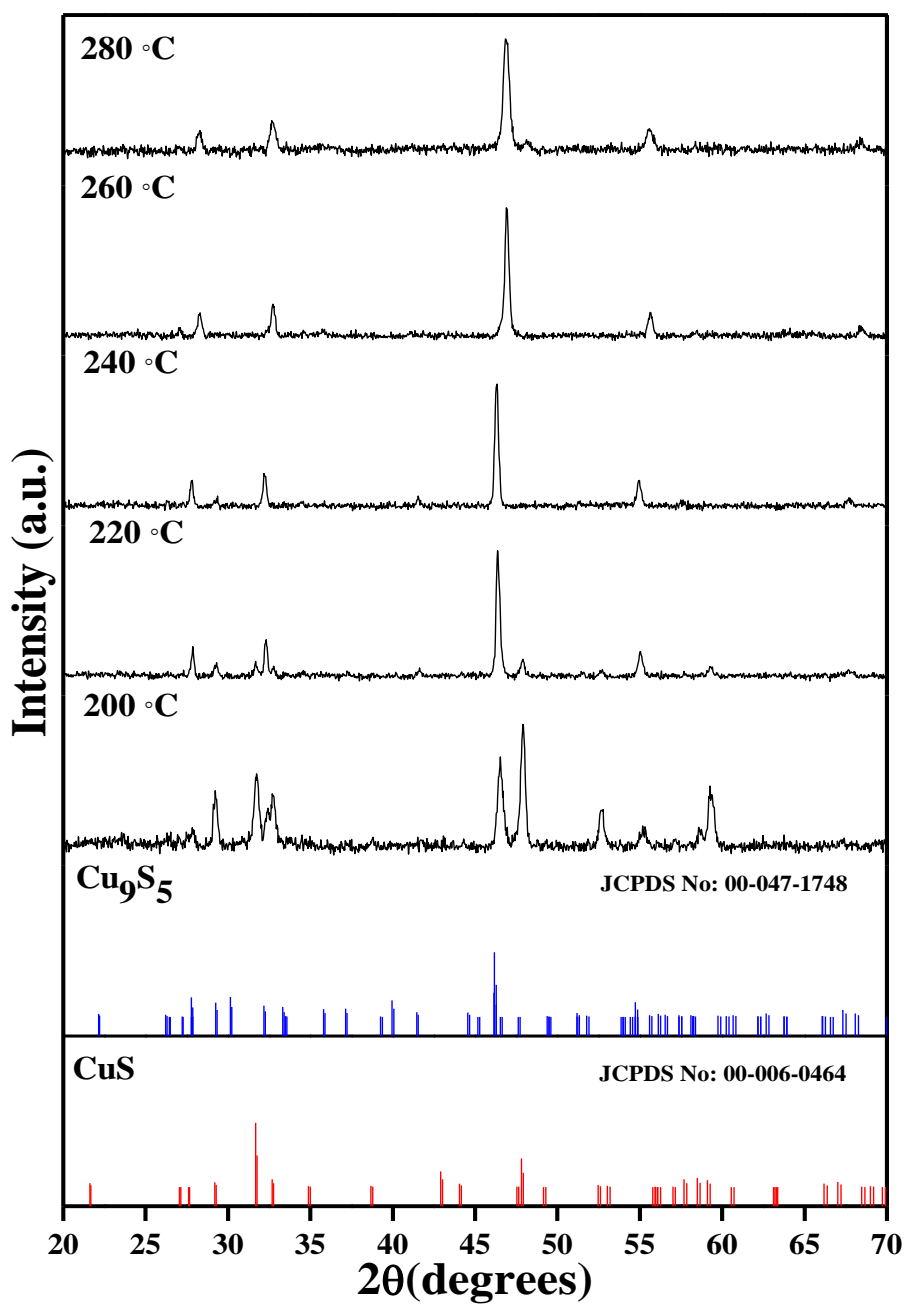

Figure 23. Powder $\mathrm{X}$-ray diffraction patterns showing the evolution of pure phase $\mathrm{Cu}_{9} \mathrm{~S}_{5}$ from the thermolysis of $\left[\mathrm{Cu}\left(\mathrm{S}_{2} \mathrm{CNMePh}\right)_{2}\right]$ in OLA.

Copper(II) bis(dithiocarbamates) have also been exploited for the introduction of copper as a dopant in metal sulfides [188], resulting in improved charge carrier concentration and current conductivity. Two examples are the preparation of $\mathrm{Cu}$-doped $\mathrm{FeS}_{2}$ [189] and Cu-doped SnS [188]; bandgap modulation was achieved by varying the percentage of copper. In an attempting to form doped metal sulfides using the SSP route, it is important that all precursors decompose within a similar temperature range, as this allows for their simultaneous decomposition ensuring that dopant levels can be controlled by varying SSP stoichiometries.

The decomposition mechanism of copper dithiocarbamates has not been extensively studied and, thus, we look to related systems for direction. The decomposition of $\left[\mathrm{Ni}\left(\mathrm{S}_{2} \mathrm{CNR}_{2}\right)_{2}\right]$ in primary amines has been shown to proceed by the initial coordination of the amine to form five or six coordinate adducts [190]. Following this, and at higher temperatures, amide exchange occurs with $\left[\mathrm{Ni}\left(\mathrm{S}_{2} \mathrm{CNR}_{2}\right)_{2}\right]$ converting to $\left[\mathrm{Ni}\left(\mathrm{S}_{2} \mathrm{CNHR}_{2}\right)_{2}\right]$, and it is these primary amine derivatives that decompose via deprotonation and loss of isothiocyanate [191]. While this decomposition pathway has not been proved for analogous $\mathrm{Cu}$ (II) bis(dithiocarbamates), the structural similarly between $\mathrm{d}^{8}\left[\mathrm{Ni}\left(\mathrm{S}_{2} \mathrm{CNR}_{2}\right)_{2}\right]$ and $\mathrm{d}^{9}$ $\left[\mathrm{Cu}\left(\mathrm{S}_{2} \mathrm{CNR}_{2}\right)_{2}\right]$ make it tempting to suggest a similar mechanism operates for copper. Likewise, for $\left[\mathrm{Fe}\left(\mathrm{S}_{2} \mathrm{CNR}_{2}\right)_{3}\right]$, the initial amine coordination is followed by an intramolecular electron transfer to generate $\left[\mathrm{Fe}\left(\mathrm{S}_{2} \mathrm{CNR}_{2}\right)_{2}\right]$ and half an equivalent of the oxidised form of the dithiocarbamate, namely thiuram disulfide $\left(\mathrm{R}_{2} \mathrm{NCS}_{2}\right)_{2}$ [192]. Thus, while reduction of $\mathrm{Ni}(\mathrm{II})$ to $\mathrm{Ni}(\mathrm{I})$ is unfavourable, reduction of $\left[\mathrm{Cu}\left(\mathrm{S}_{2} \mathrm{CNR}_{2}\right)_{2}\right]$ occurs at low potentials and 
thus $\mathrm{Cu}(\mathrm{I})$ species may also be prevalent. Indeed, a number of authors report an initial conversion of brown solutions to yellow, with this colour change being associated with the formation of $\mathrm{Cu}(\mathrm{I})$. These two potential decomposition pathways are summarised in Figure 24. Importantly, in the amide-exchange process at nickel, the zwitterionic adducts are shown to be transition states, and not adducts as has been erroneously suggested by some authors [182].

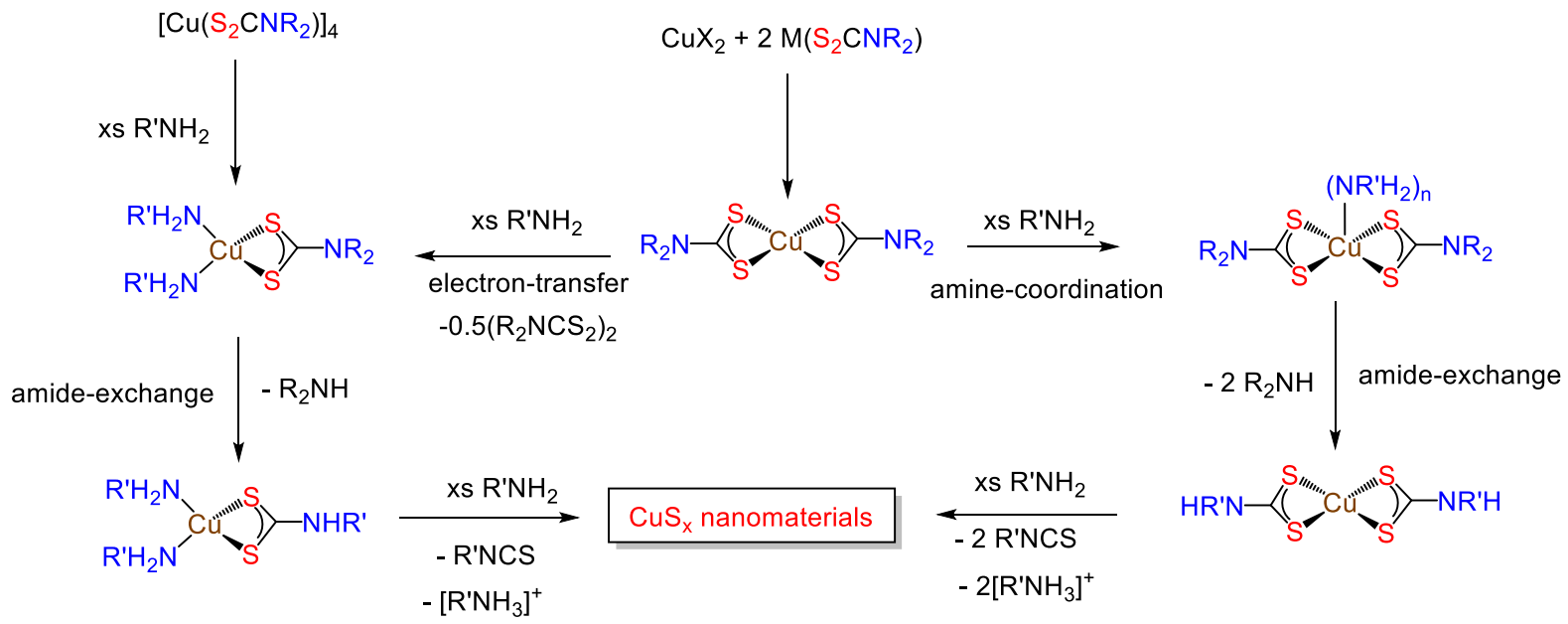

Figure 24. Proposed mechanism for the formation of copper sulfides upon heating copper dithiocarbamate SSPs in primary amines.

\subsection{Ternary Metal Sulfides}

Copper dithiocarbamates have been used as SSPs to prepare a range of ternary metal sulfides, the most important of which is copper indium sulfide, $\mathrm{CuInS}_{2}$. This is a semiconductor with a bandgap (bulk) of ca. $1.45 \mathrm{eV}$, and its high absorption coefficient in the visible region, exceptional radiation hardness and a pronounced defect tolerance, make it suitable for a range of applications. Further, the metals can be adjusted to fine-tune the properties of the material; when the $\mathrm{Cu}$ :In ratio is $<1$, they display n-type semiconductor properties, while when $>1$ they are p-type semiconductors. The Bohr exciton radius of $\mathrm{CuInS}_{2}$ is $4.1 \mathrm{~nm}$, and quantum confinement effects can be observed in nanocrystals of up to ca. $8 \mathrm{~nm}$. At room temperature, $\mathrm{CuInS}_{2}$ adopts the chalcopyrite structure, but at elevated temperatures, a random distribution of cations is thermodynamically favoured, leading to the zinc blende structure at $>980^{\circ} \mathrm{C}$, and wurtzite at $>1045^{\circ} \mathrm{C}$. A range of copper and indium dithiocarbamates have been used in the synthesis of $\mathrm{CuInS}_{2}$. A synthetic challenge arises from the different Lewis acidities of hard $\operatorname{In}(\mathrm{III})$ and soft $\mathrm{Cu}(\mathrm{I})$. For this reason, the dithiocarbamate SSP approach is extremely useful since both $\left[\operatorname{In}\left(\mathrm{S}_{2} \mathrm{CNR}_{2}\right)_{3}\right]$ and $\left[\mathrm{Cu}\left(\mathrm{S}_{2} \mathrm{CNR}_{2}\right)_{2}\right] /\left[\mathrm{Cu}\left(\mathrm{S}_{2} \mathrm{CNR}_{2}\right)\right]_{4}$ are easily prepared and handled, and they show similar solubility and decomposition profiles in a range of coordinating solvents.

The SSP approach to CuInS 2 was first reported by Cui et al. who decomposed mixtures of $\left[\mathrm{In}\left(\mathrm{S}_{2} \mathrm{CNEt}_{2}\right)_{3}\right] /\left[\mathrm{Cu}\left(\mathrm{S}_{2} \mathrm{CNEt}_{2}\right)_{2}\right]$ in ethylenediamine (en) at $195{ }^{\circ} \mathrm{C}$ [193], and soon after, $\mathrm{O}^{\prime}$ Brien prepared thin films of $\mathrm{CuInS}_{2}$ on a range of substrates by aerosol-assisted chemical vapor deposition (AACVD) at $250-500{ }^{\circ} \mathrm{C}$ of $\left[\mathrm{Cu}\left(\mathrm{S}_{2} \mathrm{CNMeHex}\right)_{2}\right] /\left[\mathrm{In}\left(\mathrm{S}_{2} \mathrm{CNMeHex}\right)_{3}\right]$ [194]. While pure chalcopyrite films can be produced, the ratio of the two SSPs must be carefully controlled, with indium-rich mixtures affording $\beta-\operatorname{In}_{2} S_{3}$ as the major product, while copperrich precursors give mixtures of $\mathrm{Cu}_{1.75-2} \mathrm{~S}$ and $\mathrm{CuInS}_{2}$. In 2008, Yang, $\mathrm{Lu}$ and co-workers developed a simple method to produce $\mathrm{CuInS}_{2}$ nanomaterials with both the zinc blende and wurtzite structures [195]. This involves injection of $\left[\mathrm{In}\left(\mathrm{S}_{2} \mathrm{CNEt}_{2}\right)_{3}\right] /\left[\mathrm{Cu}\left(\mathrm{S}_{2} \mathrm{CNEt}_{2}\right)_{2}\right]$ into OLA at $200{ }^{\circ} \mathrm{C}$ and affords $\mathrm{CuInS}_{2}$ within minutes. The phase can be adjusted by adding different capping agents to the decomposition mixtures; with oleic acid, the zinc blende phase results, while with DDT, the kinetically metastable wurtzite phase is generated. Further, by simply varying the ratio of the two SSPs the stoichiometry of the zinc 
blende particles can be controlled in the range $\mathrm{Cu}_{3} \operatorname{InS}_{3.1}$ to $\mathrm{CuIn} 2.2 \mathrm{~S}_{3.8}$, and the size of the nanocrystals can also be adjusted by varying the temperature and the amount of OLA. Other copper dithiocarbamates can also be used as SSPs. For example, wurtzite $\mathrm{CuInS}_{2}$ nanocrystals have been prepared in OLA at $200{ }^{\circ} \mathrm{C}$ using $\left[\mathrm{Cu}\left(\mathrm{S}_{2} \mathrm{CNBu}_{2}\right)_{2}\right]$ [196], while the indium source can also be varied to afford mixtures of wurtzite and chalcopyrite phases, which show dual emission in the visible $(600-700 \mathrm{~nm})$ and near-IR $(700-800 \mathrm{~nm})$ [197]. The decomposition of mixtures of $\left[\mathrm{Cu}\left\{\mathrm{S}_{2} \mathrm{CMe}\left(\mathrm{CH}_{2} \mathrm{CH}_{2} \mathrm{OH}\right)\right\}_{2}\right]$ and $\left[\mathrm{In}\left\{\mathrm{S}_{2} \mathrm{CMe}\left(\mathrm{CH}_{2} \mathrm{CH}_{2} \mathrm{OH}\right)\right\}_{3}\right]$ affords ternary nanoparticles $\left(\mathrm{CuInS}_{2}\right)$ of the wurtzite phase. A study of their electrochemical properties using cyclic voltametric, square-wave voltammograms and electronic impedance spectroscopy showed that the nanoparticles exhibited good electrocatalytic activities and could be useful in areas such as photovoltaics [198]. The use of copper dithiocarbamates as SSPs to $\mathrm{CuGaS}_{2}$ has been less widely studied, but methods used broadly follow those described above for indium, using $\left[\mathrm{Ga}\left(\mathrm{S}_{2} \mathrm{CNR}_{2}\right)_{3}\right]$ as a precursor [194].

While the formation of these materials is clearly a multi-step process, some mechanistic insight has been elucidated. Upon heating $\left[\mathrm{Cu}\left(\mathrm{S}_{2} \mathrm{CNEt}_{2}\right)_{2}\right]$ and $\left[\operatorname{In}\left(\mathrm{S}_{2} \mathrm{CNEt}_{2}\right)_{3}\right]$ in OLA/DDT mixtures at $180^{\circ} \mathrm{C}$, after a few minutes the solution changes from yellow to brown, with this being associated with the formation of $\mathrm{Cu}_{1.75} \mathrm{~S}$ [199]. This acts as a catalyst for the growth of $\mathrm{CuInS}_{2}$ nanoribbons, which have tips of $\mathrm{Cu}_{1.75} \mathrm{~S}$. The tip size is ca. $10-15 \mathrm{~nm}$ in the initial stages of nanoribbon growth but increased to ca. $20-40 \mathrm{~nm}$ in the final stages. The produced $\mathrm{CuInS}_{2}$ nanoribbons are $2-3 \mu \mathrm{m}$ by $20-50 \mathrm{~nm}$ and have a ripple-like structure resulting from bending strain. Wurtzite $\mathrm{CuInS}_{2}$ nanowires can also be prepared using other catalytic centres, for example $\mathrm{Ag}_{2} \mathrm{~S}$, which is rapidly generated upon adding $\left[\mathrm{Ag}\left(\mathrm{S}_{2} \mathrm{CNEt}_{2}\right)\right]_{6}$ to the reaction mixture [200]. It has been suggested that the high mobility of the group 11 cations promotes the formation of $\mathrm{Cu}^{+} / \mathrm{Ag}^{+}$vacancies in the first-formed $\mathrm{M}_{2} \mathrm{~S}$ nanoparticles, which facilitates diffusion of molecular copper and indium species into $\mathrm{M}_{2} \mathrm{~S}$ to reach supersaturated states. Nanospheres and nanopencils of $\mathrm{CuInS}_{2}$ can also be prepared. For example, heating $\left[\mathrm{Cu}\left(\mathrm{S}_{2} \mathrm{CNEt}_{2}\right)_{2}\right] /\left[\operatorname{In}\left(\mathrm{S}_{2} \mathrm{CNEt}_{2}\right)_{3}\right]$ in OLA/DDT at $200{ }^{\circ} \mathrm{C}$ gives wurtzite nanopencils with diameters of $10 \mathrm{~nm}$ and lengths of $55 \mathrm{~nm}$, one end of which is narrowed to a point [201]. Adding the chelate 1,10-phenathroline changes the morphology, so-called tadpole-like structures resulting with lengths of $140 \mathrm{~nm}$ and diameters of $25 \mathrm{~nm}$. High resolution transmission electron microscopy (HRTEM) shows that growth of the nanopencils is along the (001) direction, and it is suggested that 1,10-phen may disrupt this growth process.

An alternative strategy is to incorporate copper and indium into the same SSP as championed by Nomura and co-workers, who prepared heterobimetallic complexes, such as $\left[{ }^{\mathrm{i}} \mathrm{Bu}_{2} \mathrm{In}(\mu-\mathrm{SPr}) \mathrm{Cu}\left(\mathrm{S}_{2} \mathrm{CNBu}_{2}\right)\right]$ from the reaction of $\left[{ }^{\mathrm{i}} \mathrm{Bu}_{2} \mathrm{InSPr}\right]$ and $\left[\mathrm{Cu}\left(\mathrm{S}_{2} \mathrm{CNBu}_{2}\right)_{2}\right]$, and used them to prepare thin films of $\mathrm{CuInS}_{2}$ [201,202]. The heterobimetallic complexes were not fully characterised and this approach has not been widely developed until recently when Nowotny, Schneider and co-workers prepared and crystallographically characterised $\left[\left(\mathrm{Ph}_{3} \mathrm{P}\right)_{2} \mathrm{Cu}\left(\mu-\mathrm{S}_{2} \mathrm{C}_{2} \mathrm{O}_{2}\right) \operatorname{In}\left(\mathrm{S}_{2} \mathrm{CNEt}_{2}\right)_{2}\right]$. They showed that hot-injection of this SSP into OLA at $240{ }^{\circ} \mathrm{C}$ gave nanospheres of $\mathrm{CuInS}_{2}$ with extremely small diameters (ca. $2 \mathrm{~nm}$ ) [203].

Semiconductors $\mathrm{CuInS}_{2}$ and $\mathrm{ZnS}$ can be combined to make novel functional materials, and the SSP approach is an effective route. For example, in 2009, $\mathrm{Xu}$ and co-workers reported that the simple decomposition of mixtures of $\left[\mathrm{Zn}\left(\mathrm{S}_{2} \mathrm{CNEt}_{2}\right)_{2}\right],\left[\mathrm{Cu}\left(\mathrm{S}_{2} \mathrm{CNEt}_{2}\right)_{2}\right]$ and $\left[\mathrm{In}\left(\mathrm{S}_{2} \mathrm{CNEt}_{2}\right)_{3}\right]$ in octadecane (OD)/OLA in the presence of capping agents could be used to access almost monodispersed nanocrystals of $\left(\mathrm{CuInS}_{2}\right)_{x}(\mathrm{ZnS})_{1-x}$ alloys over the entire composition range [204]. As with $\mathrm{CuInS}_{2}$ alone, both zinc blende and wurtzite phases can be formed, being easily controlled by the judicious choice of a capping agent, as shown for pure $\mathrm{CuInS}_{2}$ [205]. More complex materials can also easily be made, and by simply adding $\left[\mathrm{Cd}\left(\mathrm{S}_{2} \mathrm{CNEt}_{2}\right)_{2}\right]$ to the decomposition mixture, solid-solution nanocrystals of $\left(\mathrm{CuInS}_{2}\right)_{x}(\mathrm{ZnS})_{y}(\mathrm{CdS})_{z}$ can be accessed [206]. The morphology of these materials can also be tuned. The decomposition of mixtures of diethyl dithiocarbamate complexes in OA/DDT affords nanobelts of $\left(\mathrm{CuInS}_{2}\right)_{x}(\mathrm{ZnS})_{1-x}$ with lengths of ca. 3-5 $\mu \mathrm{m}$ and widths of 50-100 nm [207]. A study of the growth process of the nanobelts showed 
the initial formation of $\mathrm{Cu}_{1.75} \mathrm{~S}$ nanoparticles, presumably from the rapid decomposition of $\left[\mathrm{Cu}\left(\mathrm{S}_{2} \mathrm{CNEt}_{2}\right)_{2}\right]$. These developed into nanowires by a solution-liquid-solid growth process, with matchstick-like structures observed in the early stages. Simply changing the reaction medium leads to the formation of alloys with very different morphologies, for example spherical $\left(\mathrm{CuInS}_{2}\right)_{x}(\mathrm{ZnS})_{1-x}$ nanocrystals of ca. $7.1 \mathrm{~nm}$ diameter with the zinc blende structure have been prepared through the in situ ethanolamine-derived SSPs in dimethyl formamide (DMF) at $180^{\circ} \mathrm{C}$ [208].

Copper dithiocarbamates have also been used in conjunction with other metal dithiocarbamates including bismuth, tin, iron and antimony as dual SSPs for the synthesis of a range of ternary metal sulfides, including copper antimony sulfides $\left(\mathrm{CuSbS}_{2}, \mathrm{Cu}_{3} \mathrm{SbS}_{4}\right.$, $\mathrm{Cu}_{12} \mathrm{Sb}_{4} \mathrm{~S}_{13}$ and $\left.\mathrm{Cu}_{3} \mathrm{SbS}_{3}\right)$ [209], copper bismuth sulfides $\left(\mathrm{Cu}_{3} \mathrm{BiS}_{3}\right.$, and $\left.\mathrm{Cu}_{4} \mathrm{BiS}_{9}\right)$ [210], copper tin sulfides $\left(\mathrm{Cu}_{2} \mathrm{SnS}_{3}\right.$, and $\left.\mathrm{Cu}_{4} \mathrm{SnS}_{4}\right)$ [211] and copper iron sulfides $\left(\mathrm{CuFe}_{2} \mathrm{~S}_{3}\right.$ and $\mathrm{Cu}_{5} \mathrm{FeS}_{4}$ ) [18]. The unique chemical, physical and structural properties of these ternary copper sulfides makes them potential materials for optoelectronic devices such as solar cells [212], superconductors and sensors. These unique properties arise from the increased stoichiometric variation and possible synergy originating from the introduction of a third element into the structure of the metal sulfide [213,214].

Most researchers use $\left[\mathrm{Cu}\left(\mathrm{S}_{2} \mathrm{CNEt}_{2}\right)_{2}\right]$ as the copper source as detailed in the syntheses of $\mathrm{Cu}_{3} \mathrm{BiS}_{3}, \mathrm{Cu}_{4} \mathrm{Bi}_{4} \mathrm{~S}_{9}$ and $\mathrm{Cu}_{3} \mathrm{SnS}_{4}$, with different stoichiometries resulting upon variation of the precursor concentrations, temperature and solvent, and in some instances, the morphology can also be tuned [210]. Xu et al. reported the synthesis of $\mathrm{CuSbS}_{2}$ and $\mathrm{Cu}_{12} \mathrm{Sb}_{4} \mathrm{~S}_{13}$ nanomaterials by varying the OLA/DDT solvent ratio, while maintaining a constant precursor ratio and reaction temperature [209]. The addition of 1,10-phenanthroline (phen) resulted in isolation of $\mathrm{Cu}_{3} \mathrm{SbS}_{3}$ stoichiometry, purportedly via the in situ formation of adduct $\left[\mathrm{Cu}\left(\mathrm{S}_{2} \mathrm{CNEt}_{2}\right)_{2}(1,10-\right.$ phen $\left.)\right]$, although we note that this complex is not known and this more likely results from some selective metal chelation, which changes the metal-substrate ratio. Since these compounds exhibit stoichiometric and morphologydependent optical and electrical properties, dithiocarbamate complexes of copper provides a facile route to their controlled syntheses. Co-thermolysis of $\left[\mathrm{SnClBu}\left(\mathrm{S}_{2} \mathrm{CNMePh}\right)\right]$ and $\left[\mathrm{Cu}\left(\mathrm{S}_{2} \mathrm{CNEtPh}\right)_{2}\right]$ in different molar ratios provides a simple route to a range of copper tin sulfides. Thus, with an equimolar ratio of the two SSPs, pure $\mathrm{Cu}_{2} \mathrm{SnS}_{3}$ results, but as the amount of $\left[\mathrm{Cu}\left(\mathrm{S}_{2} \mathrm{CNEtPh}\right)_{2}\right]$ is increased, secondary peaks are seen in the PXRD attributed to tetragonal $\mathrm{Cu}_{2} \mathrm{~S}$ and orthorhombic $\mathrm{Cu}_{4} \mathrm{SnS}_{4}$ [215].

A number of iron copper sulfides have been prepared from dithiocarbamate SSPs. Gupta and co-workers used the hot-injection of $\left[\mathrm{Cu}\left(\mathrm{S}_{2} \mathrm{CNEt}_{2}\right)_{2}\right] /\left[\mathrm{Fe}\left(\mathrm{S}_{2} \mathrm{CNEt}_{2}\right)_{3}\right]$ into a solution of sulfur in OLA/TOP at $180{ }^{\circ} \mathrm{C}$, to prepare nanocrystals of $\mathrm{CuFeS}_{2}$ with an average diameter of ca. $12 \mathrm{~nm}$ [216], the morphology of which could be tuned from spherical to pyramidal, the latter resulting upon the addition of $\left[\mathrm{Cu}(\mathrm{acac})_{2}\right]$ (Figure 25a,b). Hogarth and co-workers reported that heating $\left[\mathrm{Cu}\left(\mathrm{S}_{2} \mathrm{CN}^{\mathrm{i}} \mathrm{Bu}_{2}\right)_{2}\right] /\left[\mathrm{Fe}\left(\mathrm{S}_{2} \mathrm{CN}^{\mathrm{i}} \mathrm{Bu}_{2}\right)_{3}\right]$ in OLA at $230{ }^{\circ} \mathrm{C}$ gave spherical nanocrystals of ca. $11 \mathrm{~nm}$ in diameter, being slightly reduced upon the addition of ${ }^{\mathrm{i}} \mathrm{Bu}_{4}$-TDS to the decomposition mixture [217]. 

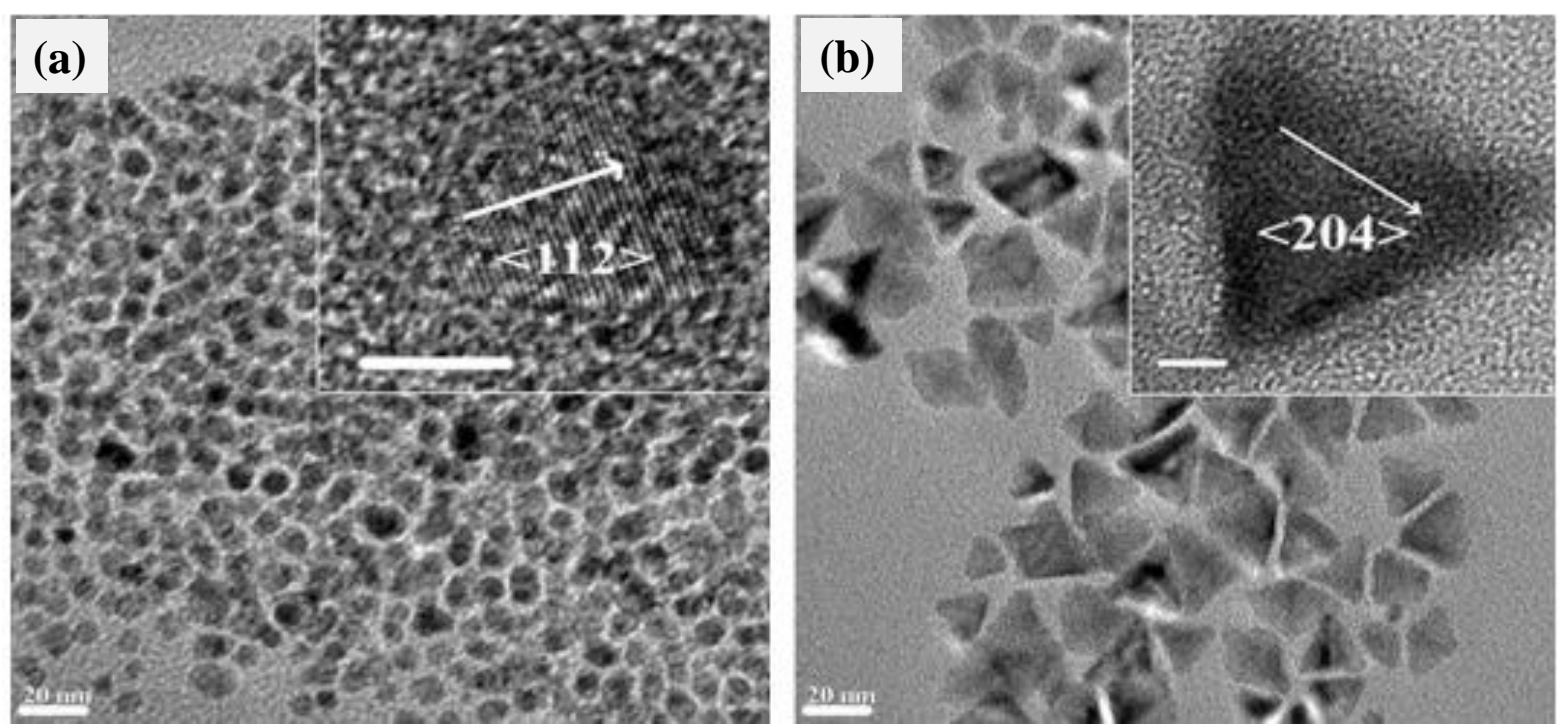

Figure 25. TEM of $\mathrm{CuFeS}_{2}$ nanocrystals with (a) spherical and (b) pyramidal morphology (HRTEM images shown in the insets). Reproduced with permission [216]. Copyright 2010 Elsevier.

\subsection{Quaternary Metal Sulfides}

Copper-containing $\mathrm{Cu}_{2} \mathrm{ZnSnS}_{4}$ (CZTS) and $\mathrm{Cu}_{2} \mathrm{ZnSnSe}_{4}$ (CZTSe) are amongst the most widely studied quaternary semiconductors as they show potential for applications in thin film solar cells, having power conversion efficiencies of ca. $10 \%$. Over the past decade, there has been many reports of the use of dithiocarbamate SSPs for the synthesis of CZTS thin films and QDs. The formation of quaternary (and multinary) sulfides via the SSP approach adds a further level of complexity with the reactivity of three or more components having to be considered, which can lead to issues of stoichiometric control, while there is also a tendency to generate a plurality of compositional phases in the early stages. Further, for thin film synthesis, the three precursors must have similar volatility and decomposition temperatures/profiles. For the diethyldithiocarbamate derivatives of copper, zinc and tin, their decomposition occurs at 220,240 and $174{ }^{\circ} \mathrm{C}$, respectively, and the low value of the latter may lead to the initial formation of SnS. O'Brien and co-workers thus utilised the higher decomposition temperature of $\left[\mathrm{Sn}\left(\mathrm{S}_{2} \mathrm{CNBu}_{2}\right)_{4}\right]\left(300^{\circ} \mathrm{C}\right)$ to form a suitable SSP mixture [218] for the first AACVD synthesis of CZTS thin films. They deposited these at $360{ }^{\circ} \mathrm{C}$ to obtain films of kesterite ca. $690 \mathrm{~nm}$ thick, which could be increased to $1.15 \mu \mathrm{m}$ at $400{ }^{\circ} \mathrm{C}$, with optical bandgaps varying at $1.3-1.5 \mathrm{eV}$. CZTS thin films can also be prepared from dithiocarbamate SSPs nanoparticles via the initial formation of nanoparticles upon initial decomposition in OLA followed by drop-casting toluene suspensions of these onto substrates, with films of up to $10 \mu \mathrm{m}$ being accessible [219]. Another approach is to aerosol spray toluene solutions of the diethyl-dithiocarbamate complexes onto a hot substrate at ca. $400{ }^{\circ} \mathrm{C}$, which gives thin films comprised of nanoplatelets of CZTS. Further studies have shown the initial formation of a copper-rich phase and this promotes later anisotropic growth [220]. In solvothermal syntheses from OLA/DDT, the initial formation of $\mathrm{Cu}_{2} \mathrm{~S}$ nanoparticles has also been observed, and these in turn catalyse the growth of CZTS [221]. Thus, a consistent picture emerges whereby the copper dithiocarbamate SSP decomposes first, and the generated copper sulfide catalyses later decomposition processes.

As shown in Figure 24, it is postulated that primary amine complexes [ $\left.\mathrm{Cu}\left(\mathrm{S}_{2} \mathrm{CNHR}\right)_{2}\right]$ are key intermediates in the formation of copper sulfides. These appear to be unstable, and to date, no well-characterised examples have been reported. They may be generated in situ and it has been reported that the addition of $\mathrm{CS}_{2}$ to the primary amine solution containing copper, zinc and tin salts and spin-coating the mixture onto substrates, then heating at $320^{\circ} \mathrm{C}$ for a few minutes affords thin films of CZTS [222,223]. This suggests that $\left[\mathrm{M}\left(\mathrm{S}_{2} \mathrm{CNHR}\right)_{n}\right]$, including $\left[\mathrm{Cu}\left(\mathrm{S}_{2} \mathrm{CNHR}\right)_{2}\right]$, are generated but rapidly decompose. The quality of the films is dependent upon the nature of the amine dependent upon the amine; 
with ethanolamine giving the best-quality films. These results suggest that both the rates of formation and decomposition of $\left[\mathrm{Cu}\left(\mathrm{S}_{2} \mathrm{CNHR}\right)_{2}\right]$ (and tin and zinc) complexes are likely substituent dependent. Further studies into this exciting discovery are eagerly awaited.

\section{Biological Applications}

Copper is an essential element for most aerobic organisms, being present in metalloproteins and metal-labile pools [224], and consequently, copper homeostasis is critically important to normal human physiology. This is exemplified by the life-threatening impact of copper deficiency and overload associated with Menkes and Wilson's disease, respectively $[225,226]$. The biological effects of dithiocarbamates centre on their ability to exert both pro-oxidant and antioxidant effects [227], while their high metal-chelating ability allows them to modulate the active sites of many metal-containing proteins [228]. In addition, the free thiol groups may also interact with other molecules such as the sulfhydryl groups. Thus, dithiocarbamates are able to inhibit enzymes and also oxidise glutathione by covalently interacting with free protein thiols [229] and glutathione peroxidase-like activity [230]. They can also affect cellular detoxification mechanisms due to their ability to subdue hepatic microsomal process of drug metabolism [231] and also suppress glutathione S-transferases [232].

Given the biological importance of copper and the use of tetraethyl thiuram disulfide (Disulfiram) since the 1950s as a drug used in alcohol aversion therapy [233-235], then it is not surprising that copper dithiocarbamates, especially $\left[\mathrm{Cu}\left(\mathrm{S}_{2} \mathrm{CNEt}_{2}\right)_{2}\right]$, have been widely studied in a biological context. Thus, it has been shown that free $\mathrm{Cu}$ (II) interacts with disulfiram to afford $\left[\mathrm{Cu}\left(\mathrm{S}_{2} \mathrm{CNEt}_{2}\right)_{2}\right]$ in high yields, a transformation accompanied by the oxidative decomposition of small amounts of disulfiram [236,237]. While disulfiram itself has little effect on cancer cells, in the presence of $\mathrm{Cu}(\mathrm{II}) \mathrm{IC}_{50}$, values in the nanomolar range have been found against a number of cancer cell lines, and consequently copper-dithiocarbamates have been widely studied in a biological domain, particularly as anticancer agents. Copper dithiocarbamates are able to alter cancer cell metabolism and, in addition, their ability to selectively respond to normal and tumour cells differently forms the basis of their development as complexes with antineoplastic properties [238]. Using complexes derived from biologically active amines suggests potential for both metal and ligand interference with a pathogen's life cycle [239]. In accordance with Tweedy's theory, metal complexes would exhibit greater biological activity than the corresponding ligand, with this being attributed to increased $\pi$-electron delocalisation in the chelate ring. Chelation results in a reduction in the polarity of metal ions, which enhances the lipophilic nature of chelates and ultimately improves penetration of the lipid layer of the microbial cell membrane and blocking of enzyme metal binding sites [240].

\subsection{Anticancer Agents}

Cancer cells have a high copper demand for their maintenance, proliferation and metastasis. While platinum complexes are the most widely developed metal-based anticancer agent [241], platinum resistance has led to the consideration of other metals, especially copper [242], complexes of which have been found to induce cancer cell death through the generation of reactive oxygen species (ROS), and by proteosome inhibition. Especially in respect of the latter, copper dithiocarbamates have shown promise in preclinical studies [243]. Detailed molecular mechanisms underlying their anticancer activity remain largely unknown, but mechanistic studies have shown that they can act as DNA intercalators [244], proteasome inhibitors [245], inhibitors of nuclear factor kappa B (NF-kB) [246] and are also able to inactivate numerous metal-containing enzymes [247].

As stated above, disulfiram alone has poor anticancer activity but does have the ability to transverse biological membranes, including the blood-brain barrier. It is also easily reduced to the dithiocarbamate by glucose reductase. Disulfiram is, nevertheless, an extremely active anticancer agent in the presence of copper ions. It does not form a stable complex with $\mathrm{Cu}(\mathrm{II})$, but the two react rapidly to afford $\left[\mathrm{Cu}\left(\mathrm{S}_{2} \mathrm{CNEt}_{2}\right)_{2}\right]$, a process 
that requires a small stoichiometric excess of disulfiram, and $\left[\mathrm{Cu}\left(\mathrm{S}_{2} \mathrm{CNEt}_{2}\right)_{2}\right]$ has been identified in the brains of mice fed with disulfiram [62]. O'Brien has proposed a mechanism for this, which involves the initial reduction of $\mathrm{Cu}$ (II) to $\mathrm{Cu}(\mathrm{I})$ with concomitant formation of bitt- $4^{2+}$, the oxidised form of disulfiram [237] (Figure 26). The bitt- $4^{2+}$ is unstable and undergoes a catastrophic decomposition, which leads to the formation of 30 electrons per molecule and leads to oxidative stress on cells [236]. This likely accounts for the massive cell death observed when exposed to disulfiram-copper mixtures $[248,249]$. Biological detection of $\left[\mathrm{Cu}\left(\mathrm{S}_{2} \mathrm{CNEt}_{2}\right)_{2}\right]$ is usually made by EPR [62] but, recently, mass spectrometry has also been used to detect this complex in A549 cell [250].<smiles>CCNC(=S)SSC(=S)NCC</smiles>
disulfiram<smiles>CCNC(=S)SSC(=S)NCC</smiles><smiles>CCN=C1SSC(=[NH+]CC)SS1</smiles>
bitt- $4^{2+}$<smiles>CCNC1=[SH][Si]2(SSC2NCC)S1</smiles>

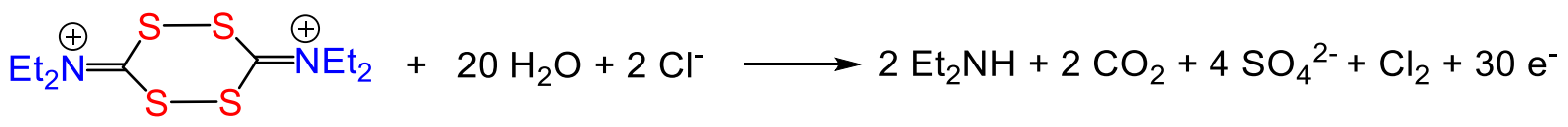

Figure 26. Proposed reactions occurring upon addition of disulfiram to $\mathrm{Cu}(\mathrm{II})$.

$\left[\mathrm{Cu}\left(\mathrm{S}_{2} \mathrm{CNEt}_{2}\right)_{2}\right]$ is also an effective anticancer [236,248,251-256] especially in vitro as are many derivatives [36,37,257-262]. This was first established for pyrrolidine dithiocarbamate, which exhibits high potency to inhibit a cancer-specific proteasome, showing a cytotoxic effect on different human tumour cells after complexation with copper. Generated $\left[\mathrm{Cu}\left(\mathrm{S}_{2} \mathrm{CNC}_{4} \mathrm{H}_{8}\right)_{2}\right]$ has also been reported to induce cellular apoptosis in both prostate and human breast cancer cells $[257,263]$ and is a potential treatment for refractory neuroblastoma in children. Zhang et al. [264] have reported suppression of the proliferation of $\mathrm{BE}(2) \mathrm{C}$ cells (a human neuroblastoma cell line) using this complex, having a higher potency than cisplatin based on $\mathrm{IC}_{50}$ values. The treatment of cancer cells resulted in an arrest of cell cycle progression and cellular apoptosis. Investigation of a series of substituted pyrrolidine complexes has allowed a structure-activity association $[265,266]$. Thus, both the ligand polarity and ring size affect the activity, with the proteasome-inhibitory ability being significantly decreased upon ring substitution by large and polar groups [266]. Furthermore, Wang et al. have reported that some pyrrolidine derivatives exhibited less inhibition activity of aldehyde dehydrogenase (ALDH) in human breast cancer cells [265].

The activity of $\left[\mathrm{Cu}\left(\mathrm{S}_{2} \mathrm{CNEt}_{2}\right)_{2}\right]$ against osteosarcoma cancer lines has been measured, showing $\mathrm{IC}_{50}$ values of $2.37 \pm 0.12 \mu \mathrm{M}$ after $24 \mathrm{~h}$, while analogous Fe(III) and $\mathrm{Cr}$ (III) complexes were inactive and $\mathrm{Mn}(\mathrm{III})$ had higher $\mathrm{IC}_{50}$ values of $13.3 \pm 1.43 \mu \mathrm{M}$ [262]. Higher levels of ubiquitin-bound proteins were observed by cells treated with $\left[\mathrm{Cu}\left(\mathrm{S}_{2} \mathrm{CNEt}_{2}\right)_{2}\right]$ and the accumulation of proteasome substrate $\operatorname{IkB} \alpha$. Apoptosis of the cancer cell was observed to proceed by the activation of caspases 3 and 7, which resulted in cleavage of PARP-1 into smaller fragments. The anticancer activity of copper dithiocarbamate complexes can be tuned by varying substituents tuning both structural and electronic properties. This was observed in the study on the antiproliferative activity of two copper complexes of dithiocarbamate glycoconjugates (glucose and galactose) on human cancer cell lines [267]. A four-fold increase in activity was observed as compared to the free ligands. Their activity was also influenced by the nature of the glycoconjugates, with the galactose-based complex showing higher antiproliferation activity as compared to glucose. 
Further, they exhibit higher activity than related zinc complexes, and the activity of the glycoconjugates is correlated with their hydrophilicity, which determines their ability to move across cell membranes.

A major barrier towards the development of $\left[\mathrm{Cu}\left(\mathrm{S}_{2} \mathrm{CNEt}_{2}\right)_{2}\right]$ and related complexes derived from non-polar secondary amines is their extremely poor water solubility $\left(<1 \mathrm{mg} \mathrm{mL}^{-1}\right)$. There are a number of possible ways around this, one being to co-deliver disulfiram and $\mathrm{Cu}(\mathrm{II})$ such that they react and generate $\left[\mathrm{Cu}\left(\mathrm{S}_{2} \mathrm{CNEt}_{2}\right)_{2}\right]$ within the tumour microenvironment [268-270]. This can be done in a number of ways, the most common being the incorporation of disulfiram and $\mathrm{Cu}(\mathrm{II})$ into a polymeric nanoparticle, for example as reported by $\mathrm{Pu}$ and co-workers who used a poly(ethylene glycol) (PEG)-b-poly(ester carbonate) (PEC) composite [270]. They established in vitro anticancer activity, although interestingly, loading the nanoparticles with pre-formed $\left[\mathrm{Cu}\left(\mathrm{S}_{2} \mathrm{CNEt}_{2}\right)_{2}\right]$ gave higher antitumor efficacy. A related approach is the in situ generation of $\left[\mathrm{Cu}\left(\mathrm{S}_{2} \mathrm{CNEt}_{2}\right)_{2}\right]$ from a prodrug, for example from an enzyme-activatable dithiocarbamate [271,272]. The prodrug was obtained by conjugating the dithiocarbamate through a leucine spacer and a $p$-aminobenzyl $(p \mathrm{AB})$ linker to the $\mathrm{C}$-terminus of peptides, cleavage of the prodrug obtained from the peptide sequences Arg-Ser-Ser-Tyr-Tyr-Ser-Leu-pAB-DTC and His-Ser-Ser-Lys-Leu-GlnLeu-pAb-DTC, respectively (point of cleavage indicated by wavy lines) resulting in the generation of $\left[\mathrm{Cu}\left(\mathrm{S}_{2} \mathrm{CNEt}_{2}\right)_{2}\right]$ (Figure 27).

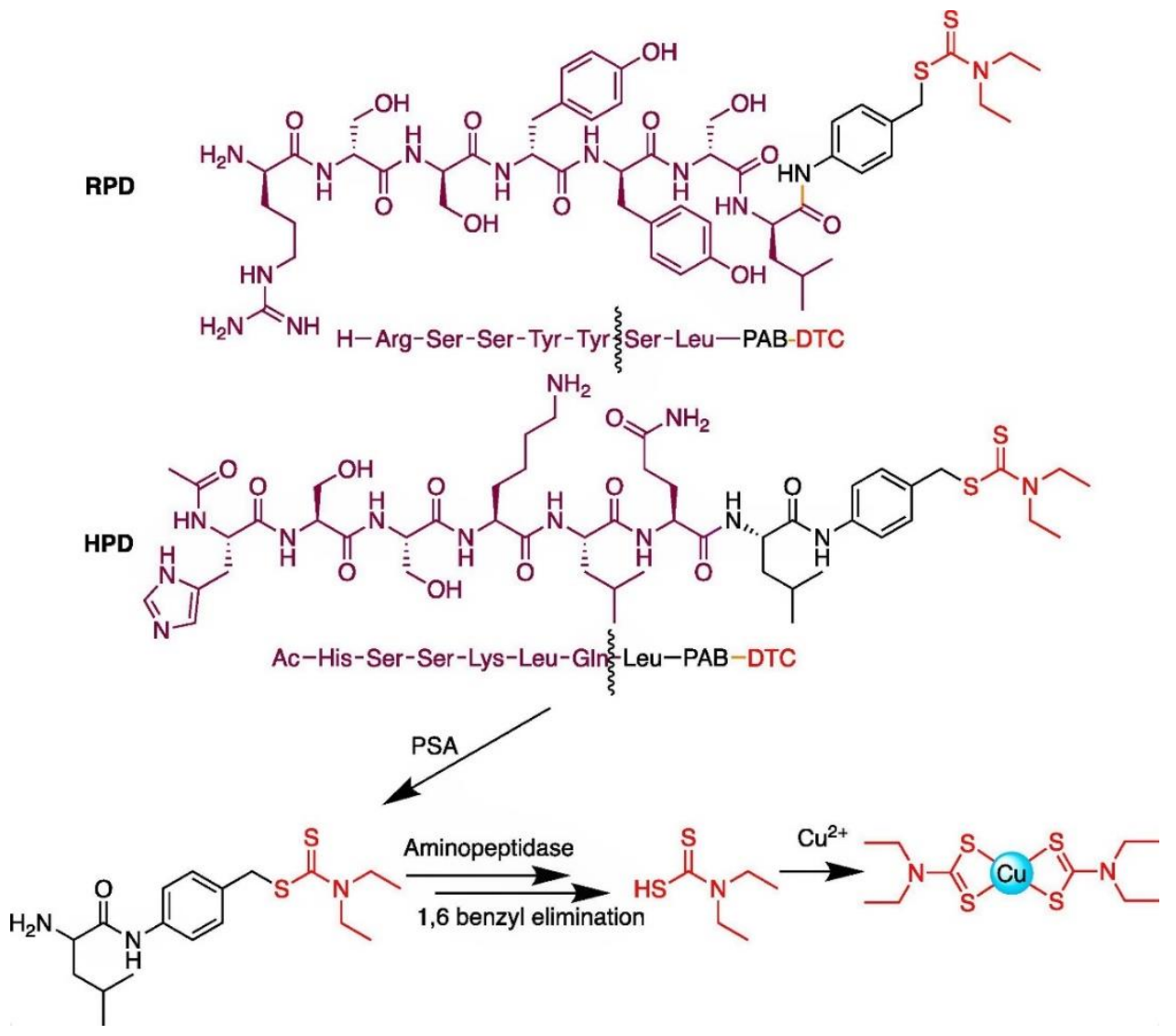

Figure 27. Chemical structures of prodrugs and the reaction scheme to the formation of $\left[\mathrm{Cu}\left(\mathrm{S}_{2} \mathrm{CNEt}_{2}\right)_{2}\right]$ via PSA-induced cleavage and amino acid trimming activity of non-specific aminopeptidases. Reproduced with permission from [271]. Copyright 2020 Elsevier.

As hinted above [270], another potential route to circumvent the low water solubility is the so-called Trojan horse approach, whereby the pre-formed copper complex is encapsulated into a vestibule. Approaches here include encapsulation in a polymer matrix [270], the aqueous core of liposomes [273], within hyaluronic acid nanoparticles [274,275] or apoferritin [276]. Related to this approach is an interesting report of stabilised metal ion ligand 
complex (SMILE) technology, whereby $\left[\mathrm{Cu}\left(\mathrm{S}_{2} \mathrm{CNEt}_{2}\right)_{2}\right]$ is embedded into nanoparticles comprised of various stabilising agents that are already approved as safe excipients by the UD Food and Drug Administration [277]. For example, PEG-PLA/[Cu( $\left.\left(\mathrm{S}_{2} \mathrm{CNEt}_{2}\right)_{2}\right]$ nanoparticles show excellent stability with only a minor loss of copper concentration after 30 days but have good activity (nanomolar) against drug-resistant DU145-TXR cells. Light-triggered $\left[\mathrm{Cu}\left(\mathrm{S}_{2} \mathrm{CNEt}_{2}\right)_{2}\right]$ release has also been developed using the Trojan horse approach $[278,279]$, for example Liu and co-workers prepared vestibules from biocompatible phase-change materials incorporating a near-infrared (NIR) dye, thus allowing $\left[\mathrm{Cu}\left(\mathrm{S}_{2} \mathrm{CNEt}_{2}\right)_{2}\right]$ release upon irradiation with an NIR laser [278].

Another approach is to modify the dithiocarbamate substituents to give enhanced water solubility, although changing these inevitably affects anticancer activity. Fregona and co-workers have utilised proline-derived complexes (Figure 2e) with some water (and DMSO) solubility $[40,41]$. Their activity is improved by supporting them on a nonionic block copolymer, with the encapsulated copper complex showing enhanced stability, bioavailability and water solubility. Some of these complexes have shown comparable activity to standard drugs, with few showing higher activity when compared to standard anticancer drugs [259]. Carbohydrate-functionalised complexes have also been prepared and studied by Fregona and co-workers, and an example (CuGlu) is shown (Figure 28) [37]. They have enhanced water solubility, and $\mathrm{CuGlu}$ shows an interesting $\mathrm{IC}_{50}$ value toward the HCT116 human colorectal carcinoma cell line, although related complexes bearing two diastereomers of D-glucose did not show any cytotoxic properties.

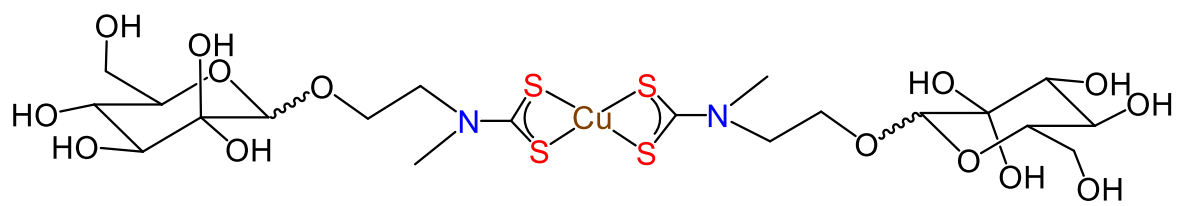

Figure 28. Line drawing of the molecular structure of a carbohydrate-functionalised dithiocarbamate complex prepared by Fregona and co-workers.

The mode of action of $\left[\mathrm{Cu}\left(\mathrm{S}_{2} \mathrm{CNEt}_{2}\right)_{2}\right]$ has been widely studied and reviewed [61]. It functions as a proteasome inhibitor, inducing apoptosis by specifically targeting the ubiquitin-proteasome pathway (UPP) [280-282]. Due to the role of UPP in the control of the expression, activities and location of various proteins, a potential strategy in the development of anticancer agents has been found in the selective suppression of proteasome and apoptotic induction in cancer cells. Recently, the $p$-97-NPL4-UFDI protein has been identified as a target for $\left[\mathrm{Cu}\left(\mathrm{S}_{2} \mathrm{CNEt}_{2}\right)_{2}\right]$, being proposed that this leads to accumulation of ubiquitinated proteins leading to a heat shock response [62]. Induction of apoptosis in neuroblastoma cells by $\left[\mathrm{Cu}\left(\mathrm{S}_{2} \mathrm{CNEt}_{2}\right)_{2}\right]$ has been shown to result from increasing levels of intracellular copper concentrations, which triggers the release of cytochrome $\mathrm{c}$ and capase activation [253], and it has also been shown to be an activator of Nrf2 in cultured vascular endothelial cells [283].

\subsection{Antimicrobial, Antibacterial, Antioxidant and SOD-like Activity}

Antimicrobial and antibacterial properties of dithiocarbamate complexes, including those of copper, have recently been reviewed by Tiekink and co-workers [284] and hence this section will cover only a brief overview of selected examples. Antimicrobial resistance is a major societal problem, with increasing resistance to so-called last-resort antibiotics such as carbapenems being of particular concern. Metallo- $\beta$-lactamases (M $\beta$ Ls) hydrolyse carbapenems, penicillins and cephalosporins, and consequently the inhibition of M $\beta$ Ls is a topic of considerable interest. In a recent communication, Yang and co-workers have shown that both disulfiram and $\left[\mathrm{Cu}\left(\mathrm{S}_{2} \mathrm{CNEt}_{2}\right)_{2}\right]$ are potent $\mathrm{M} \beta \mathrm{L}$ inhibitors [285]. While the former acts selectively on New Delhi metallo- $\beta$-lactamase (NDM-1) via covalently binding to the Cys208 residue leading to release of $\mathrm{Zn}(\mathrm{II})$, the copper complex is active at nanomolar levels against a range of $\mathrm{M} \beta \mathrm{Ls}$, a process that does not lead to loss of $\mathrm{Zn}(\mathrm{II})$. The mechanism of 
action remains to be fully elucidated, but X-ray photoelectron spectroscopy (XPS) suggests that a reduction of $\mathrm{Cu}(\mathrm{II})$ to $\mathrm{Cu}(\mathrm{I})$ occurs, a process that has been associated with oxidation of a $\mathrm{Zn}$ (II)-thiolate centre in the active site of NDM-1. As the redox chemistry of the copper centre is easily tuned via judicious choice of dithiocarbamate substituents, this suggests that further work in this area should be highly productive.

Dithiocarbamate salts have been studied for the management and control of bacteria [286], and $\mathrm{Cu}(\mathrm{II})$ bis(dithiocarbamate) complexes also show antibacterial activity, although it is normally lower than that of the free ligand [287]. This is the case for $\left[\mathrm{Cu}\left(\mathrm{S}_{2} \mathrm{CNC}_{5} \mathrm{H}_{10} \mathrm{O}\right)_{2}\right]$, which shows moderate inhibitory activity against both Gram-positive and Gram-negative bacteria [287] and a small library of $\mathrm{N}^{\prime} \mathrm{N}$-diarylformamidine-derived dithiocarbamates, the activity of which is influenced by the presence of chloro-substituents [288]. In contrast, Onwudiwe and Ekennia [24] have reported that the antibacterial activity of $\mathrm{NaS}_{2} \mathrm{CNEtPh}$ is enhanced across a broad spectrum of the bacteria even after $\mathrm{Cu}$ (II) complexation. Further studies are required to ascertain if the activity of $\left[\mathrm{Cu}\left(\mathrm{S}_{2} \mathrm{CNR}_{2}\right)_{2}\right]$ simply relates to loss of free ligand, for example upon oxidation to $\mathrm{Cu}(\mathrm{II})$. The antibacterial activity of $\mathrm{Cu}(\mathrm{I})$-phosphine complexes has also been explored, with $\left[\mathrm{Cu}\left(\mathrm{PPh}_{3}\right)_{2}\left(\mathrm{~S}_{2} \mathrm{CN}(\mathrm{R}) \mathrm{CH}_{2} \mathrm{CH}_{2} \mathrm{OH}\right)\right]$ being selective against Gram-positive bacteria $(\mathrm{R}=\mathrm{Cy}, \mathrm{iPr})$ [127]. Related $\mathrm{N}, \mathrm{N}^{\prime}$-diarylformamidine-derived dithiocarbamate complexes (Figure $2 \mathrm{~d}$ ) have also been investigated but show poor activity, possibly resulting from their inability to penetrate bacterial cell walls [289].

The release of hydrogen atoms close to the coordination core of metal complexes is responsible for the radical scavenging effect of metal complexes [290]. The presence of copper boosts the antioxidant activity of the ligands as their proton-donor capacity is enhanced, as does the presence of electron-donating groups at carbon [291,292]. The antioxidant activity of a series of copper dithiocarbamates has been reported by Oladipo et al. Using a standard assay, it was noted that their activity was significantly enhanced as compared to the free ligands [19]. Similarly, copper complexes with N'N-diarylformamidine dithiocarbamate ligands (Figure 2d) show enhanced antioxidant activity, being higher for those with symmetrical vs. unsymmetrical ligands [288]. The in vitro antioxidant activity of $\left[\mathrm{Cu}\left(\mathrm{S}_{2} \mathrm{CNEtPh}\right)_{2}\right]$ is also greater than that of the uncoordinated dithiocarbamate salt [24].

Superoxide dismutase (SOD) is a copper-containing enzyme that catalyses the conversion of superoxide to oxygen and peroxide via a $\mathrm{Cu}(\mathrm{II})-\mathrm{Cu}(\mathrm{I})$ redox couple. The SOD-like activity of $\mathrm{Cu}(\mathrm{II})$ dithiocarbamate complexes has been extensively studied by Cao and co-workers [293-298] and others [267]. In order to enhance their water solubility, they prepared a range of cyclodextrin [293,297] and $\alpha$-amino-acid [295] functionalised dithiocarbamates and their $\mathrm{Cu}$ (II) complexes. For the latter, structure-activity relationships were established between $-\log \mathrm{IC}_{50}$ values and the molar refraction of the amino acid substituents, and also the $\mathrm{Cu}(\mathrm{II})-\mathrm{Cu}(\mathrm{I})$ redox potentials. The complex derived from L-glutamic acid showed especially high SOD-like activity interpreted on the basis of EPR spectroscopy to its distorted ground-state geometry [295].

\subsection{Applications in Medical Imaging}

Copper has several positron-emitting radionuclides, ${ }^{60} \mathrm{Cu},{ }^{61} \mathrm{Cu},{ }^{62} \mathrm{Cu}$ and ${ }^{64} \mathrm{Cu}$, with a range of half-lives that are suitable for applications in molecular imaging, and radiolabelling/biodistribution of ${ }^{62} \mathrm{Cu}$-dithiocarbamate has been studied by an in vitro evaluation using non-radioactive $\mathrm{Cu}$-glycine. ${ }^{62} \mathrm{Cu}$ forms stable and neutral dithiocarbamate complexes, with a brain accumulation that is much higher than that reported for ${ }^{62} \mathrm{Cu}$ glycine [299]. ${ }^{64} \mathrm{Cu}$ emits a low-energy positron $(0.65 \mathrm{MeV})$ that allows for high-resolution positron emission tomography (PET) imaging, and the relatively long half-life $(12.7 \mathrm{~h})$ enhances its application in preclinical studies and applications in which prolonged scanning (beyond $24 \mathrm{~h}$ ) is required [300]. Hence, there is a growing interest in the use of the cyclotron-produced ${ }^{64} \mathrm{Cu}$ for diagnostic purposes [301]. Due to their ability to cross the blood brain barrier, lipophilicity, kinetic lability and potential to be easily absorbed and trapped in cells, both $\left.\left[{ }^{64} \mathrm{Cu}\left(\mathrm{S}_{2} \mathrm{CNR}_{2}\right)_{2}\right] \mathrm{RR}=\mathrm{Me}, \mathrm{Et}\right)$ have been used as brain perfusion imaging agents [302],. Charoenphun et al. [303] reported their use in labelling a 
mouse macrophage cell line (J774), which showed enhanced efficiency dependent on the dithiocarbamate utilised. Thus, while $\left[{ }^{64} \mathrm{Cu}\left(\mathrm{S}_{2} \mathrm{CNMe}_{2}\right)_{2}\right]$ exhibited the fastest and most efficient uptake, the rates of wash-out were too fast for in vivo imaging cell trafficking. The results were similar to other reported complexes of diethyldithiocarbamate and diphenyl dithiocarbamate, which suggest a rapid intracellular dissociation process.

Bifunctional dithiocarbamates, which incorporate bis(phosphonate) group(s), have been developed by de Rosales et al. [38] who prepared a dual-modality complex for medical imaging, utilising the high soft-tissue resolution of magnetic resonance imaging (MRI) and the sensitive signal of PET. The ${ }^{64} \mathrm{Cu}$ complex (Figure $2 \mathrm{~g}$ ) was synthesised and conjugated with superparamagnetic $\mathrm{Fe}_{2} \mathrm{O}_{3}$ nanoparticles as a Dual-Modality PET-MRI Agent. The ligand was designed to bind to $\mathrm{Cu}(\mathrm{II})$ through the dithiocarbamate, leaving the bis(phosphonate) ends free to bind to the surface of the $\mathrm{Fe}_{2} \mathrm{O}_{3}$ nanoparticle $[304,305]$ (Figure 29) and was successfully used in a mouse model to image draining lymph nodes.

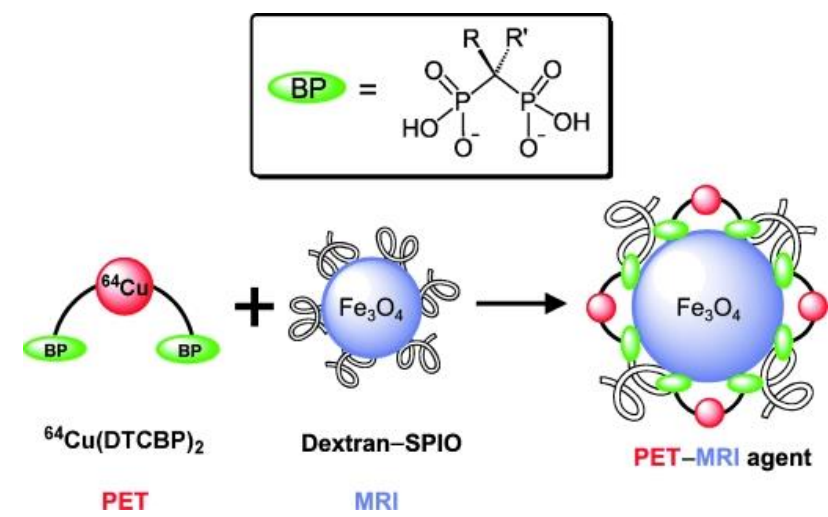

Figure 29. Conjugation reaction between the BP-based PET tracer $\left[{ }^{64} \mathrm{Cu}(\mathrm{dtcbp})_{2}\right]$ and the dextrancoated iron oxide nanoparticle MRI probe Endorem/Feridex. Reproduced with permission from [38]. Copyright 2011 John Wiley and Sons.

\section{Other Applications}

\subsection{Removal of $\mathrm{Cu}(I I)$ and Environmental Remediation}

Due to continued increases in world population and industrialisation, environmental pollution presents a global challenge, and the identification and removal of inorganic and organic pollutants has become a major research area. The main area of environmental applications of dithiocarbamates concern the adsorption of metal ions, with the high binding constants for $\mathrm{Cu}(\mathrm{II})$ and aqueous insolubility of $\left[\mathrm{Cu}\left(\mathrm{S}_{2} \mathrm{CNR}_{2}\right)_{2}\right]$ making dithiocarbamates attractive reagents for the removal of $\mathrm{Cu}$ (II) [9]. The normal approach here is to functionalise cheap and highly stable materials such as lignin [306] and starch [307]. A similar approach can also be used to remove copper from pharmaceutical reaction media down to $<10 \mathrm{ppm}$, with $\left[\mathrm{NH}_{4}\right]\left[\mathrm{S}_{2} \mathrm{CNC}_{4} \mathrm{H}_{8}\right]$ being most widely used [11]. Polymeric $\mathrm{Cu}(\mathrm{II}) \mathrm{N}, \mathrm{N}^{\prime}$-bis(dithiocarboxy)piperazine $\left([\mathrm{CuBDP}]_{n}\right.$ ) has been shown to be effective for the removal of Acid Red 73 from wastewater, with absorption being as high as $364 \mathrm{mg} \mathrm{g}^{-1}$, being significantly better than either $\left[\mathrm{Cu}\left(\mathrm{S}_{2} \mathrm{CNMe}_{2}\right)_{2}\right]$ or $\left[\mathrm{Cu}\left(\mathrm{S}_{2} \mathrm{CNEt}_{2}\right)_{2}\right]$, which are able to absorb up to 37.8 and $42.9 \mathrm{mg} \cdot \mathrm{g}^{-1}$, respectively [308]. The $\mathrm{Cu}(\mathrm{III})$ complex $\left[\mathrm{Cu}\left\{\mathrm{S}_{2} \mathrm{CN}\left(\mathrm{CH}_{2} \mathrm{CH}_{2} \mathrm{OH}\right)_{2}\right\}_{2}\right]_{3}\left[\mathrm{PW}_{12} \mathrm{O}_{40}\right]$ (Figure 30) shows high sonocatalytic activity for Rhodamine $\mathrm{B}$ dye degradation and a nanohybrid obtained from $\left[\mathrm{Cu}\left\{\mathrm{S}_{2} \mathrm{CN}\left(\mathrm{CH}_{2} \mathrm{CH}_{2} \mathrm{OH}\right)_{2}\right\}_{2}\right]$, and $\mathrm{H}_{3} \mathrm{PW}_{12} \mathrm{O}_{40}$ has high activity as an adsorbent for the removal of methylene blue, with 95\% removal being achieved within 50 min [85]. 


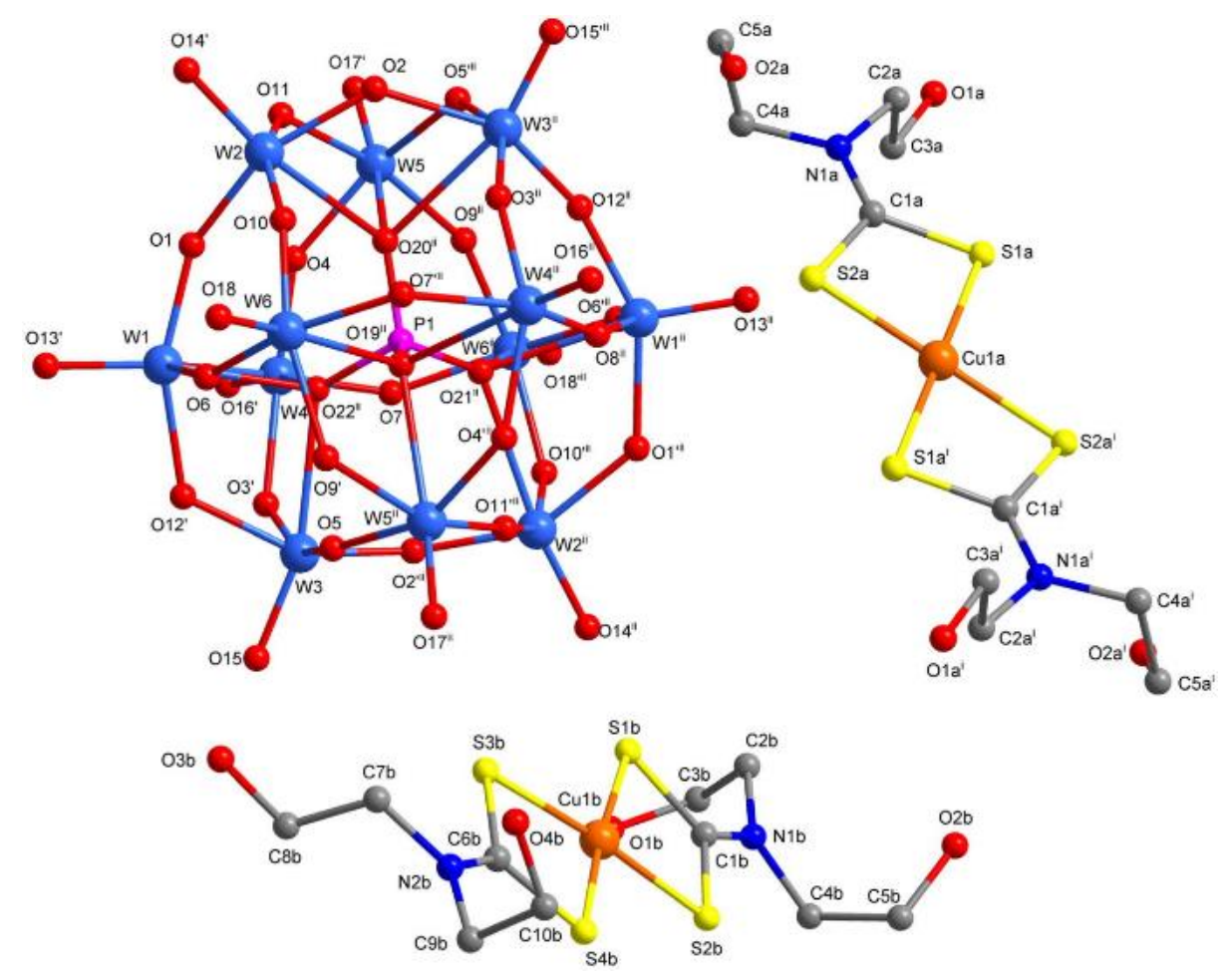

Figure 30. Organic-inorganic nanohybrid $\left[\mathrm{Cu}\left\{\mathrm{S}_{2} \mathrm{CN}\left(\mathrm{CH}_{2} \mathrm{CH}_{2} \mathrm{OH}\right)_{2}\right\}_{2}\right]_{3}\left[\mathrm{PW}_{12} \mathrm{O}_{40}\right]$. Reproduced with permission from [85]. Copyright 2017 Elsevier.

\subsection{Photovoltaic Cells}

Dye sensitisation is an important technique in improving the efficiency of $\mathrm{TiO}_{2}$-based solar cells, with potential alternatives to Si-based solar cells due to their ease of fabrication, low cost and adaptability [309]. Metal dithiocarbamate complexes have been explored as dye-sensitising agents because of their ease of functionalisation, which can lead to improved absorption and adsorption capacity of $\mathrm{TiO}_{2}$. Additionally, the $\mathrm{d}^{9}$ electronic configuration of $\mathrm{Cu}(\mathrm{II})$ may facilitate agostic interactions, supramolecular architecture stabilisation and the formation of important intermediates [21]. Maner and co-workers [21] have reported the photosensitising activity of five $\mathrm{Cu}$ (II) dithiocarbamate complexes [21], with 4-N,Ndiethylbenzyl-N-methyl substituents having the highest conversion efficiency of $3.62 \%$, being comparable to values obtained from a standard ruthenium dye. The phot-sensitising activity of the complexes appears to depend primarily on structural features, interfacial charge recombination and electron lifetime. The activity of ferrocenyl-functionalised dithiocarbamates has also been reported [310], with their efficiency as photosensitisers depending upon the nature of the heteroaromatic conjugated linkers. Similarly, the dyephotosensitising ability of a ferrocenyl-substituted dithiocarbamate complex, possessing an $-\mathrm{OH}$ group to anchor onto the $\mathrm{TiO}_{2}$ surface, was reported by Yadav [311]. Its activity is influenced by the nature of the absorption, dye-loading ability and the anchoring geometry of the complex. Compared to cobalt analogues, the efficiency of the copper complex is lower, however, but higher than related nickel species.

\subsection{Applications in Organic Transformations and Homogeneous Catalysis}

Over the past decade, a number of organic transformations have been shown to occur in the presence of copper ions (both $\mathrm{Cu}(\mathrm{I})$ and $\mathrm{Cu}(\mathrm{II})$ ) and $\mathrm{NR}_{2} \mathrm{H}-\mathrm{CS}_{2}$-base, conditions associated with the formation of $\left[\mathrm{Cu}\left(\mathrm{S}_{2} \mathrm{CNR}_{2}\right)_{2}\right]$ and /or $\left[\mathrm{Cu}\left(\mathrm{S}_{2} \mathrm{CNR}_{2}\right)\right]_{4}$. As far as we are aware, the first of these was reported in 2011 by Ma and co-workers, who showed that mixtures of secondary amines $\mathrm{CS}_{2}$ and $\mathrm{K}_{2} \mathrm{CO}_{3}$ in the presence of a range of stoichiometric amounts of copper halides efficiently affords $2-\mathrm{N}$-substituted benzothiazoles (Figure 31) [312]. 


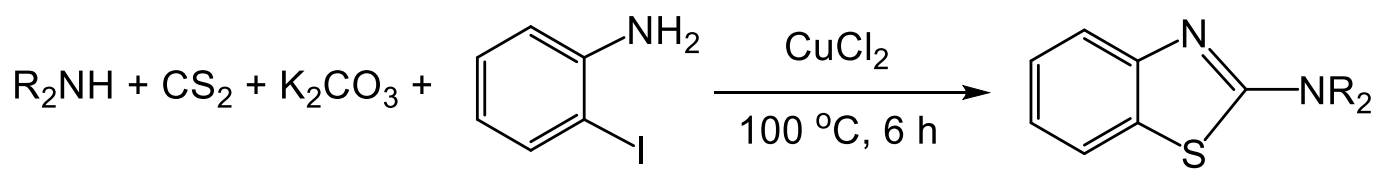

Figure 31. Formation of 2-N-substituted benzothiazoles via initial dithiocarbamate formation.

Copper dithiocarbamates have not found widespread use in homogeneous catalysis, despite having many of the attributes associated with good catalysts such as a range of accessible oxidation states and coordinative unsaturation. While the reaction discussed above is formally catalytic, the amounts of copper used are near to stoichiometric; nevertheless, there soon followed a range of related transformations in which much smaller amounts of copper were utilised either in the presence of dithiocarbamates $[313,314]$ or thiuram disulfides [315-318]. By way of example, Bolm and co-workers have reported that $\mathrm{Cu}_{2} \mathrm{O}$ is an efficient catalyst for the formation of aryl dithiocarbamates from the coupling of thiuram disulfides and aryl iodides [315]. While mechanistic details have not been fully elucidated, one proposed route is via a $\mathrm{Cu}$ (II) species $\left[\mathrm{CuAr}\left(\mathrm{S}_{2} \mathrm{CNR}_{2}\right)\right]$, which undergoes reductive-elimination of the product. This seems unlikely, and a second radical-initiated route whereby reduction of $\mathrm{Cu}(\mathrm{I})$ affords aryl radicals, which subsequently add to the thiuram disulfide, seems more plausible. In closely related transformations, $\mathrm{Cu}$ (III) intermediates, $\left[\mathrm{CuI}(\mathrm{Ar})\left(\mathrm{S}_{2} \mathrm{CNR}_{2}\right)\right]$, have been postulated, with reductive-elimination regenerating $\mathrm{Cu}(\mathrm{I})$, and this seems at least plausible [316,317].

Copper dithiocarbamates have been implicated as catalysts in living free radical polymerisation reactions [152,319-321]. For example, in the presence of 2,2'-bipyridine and AIBN, $\left[\mathrm{CuCl}\left(\mathrm{S}_{2} \mathrm{CNEt}_{2}\right) \mathrm{Cl}_{2}\right.$ has been shown to catalyse the reverse atom-transfer radical polymerisation of vinyl monomers affording polymers with low polydispersity [152]. A likely catalytic species is $\left[\mathrm{CuCl}\left(\mathrm{S}_{2} \mathrm{CNEt}_{2}\right)\left(2,2^{\prime}\right.\right.$-bipy $\left.)\right]$ in which a dithiocarbamate radical shuttles between the copper centre and the developing polymer chain.

Both $\left[\mathrm{Cu}\left(\mathrm{S}_{2} \mathrm{CNR}_{2}\right)_{2}\right]$ and $\left[\mathrm{Cu}\left(\mathrm{S}_{2} \mathrm{CNR}_{2}\right)\right]_{4}$ are active catalysts for the conversion of alkenes into aziridines using the hyper-valent iodine compound [PhI=NTs $]_{n}$ as the nitrene source [75]. Reactions occur rapidly at room temperature in $\mathrm{CH}_{2} \mathrm{Cl}_{2}$ and are easily monitored by the dissolution of oligomeric $[\mathrm{PhI}=\mathrm{NTs}]_{n}$, which leads to the initially cloudy solution turning clear. $\mathrm{Cu}(\mathrm{I})$ complexes are the most active catalysts and $\mathrm{Cu}(\mathrm{II})$ also work, but $\left[\mathrm{Cu}\left(\mathrm{S}_{2} \mathrm{CNR}_{2}\right)_{2}\right]\left[\mathrm{ClO}_{4}\right]$ are inactive $[322,323]$. The mechanism remains unknown but may involve initial coordination of $\mathrm{PhI}=\mathrm{NTs}$ to a $\mathrm{Cu}(\mathrm{I})$ centre. Unfortunately, their utility is stifled by a secondary reaction between catalyst and $\mathrm{PhI}=\mathrm{NTs}$, which leads to the formation of insoluble and catalytically inactive $\mathrm{Cu}$ (II) amides (Figure 8) possibly via the addition of NTs to sulfur followed by ring expansion.

\section{Summary and Conclusions}

In this review, we have attempted to give an overview of the coordination chemistry and various applications of copper dithiocarbamates. Some aspects of this work, such as the synthesis of $\mathrm{Cu}$ (II) bis(dithiocarbamates), $\left[\mathrm{Cu}\left(\mathrm{S}_{2} \mathrm{CNR}_{2}\right)_{2}\right]$, are very mature, and their ease of synthesis and robustness to a wide-range of variation in substituents means that they have found applications in a wide range of different areas, including materials science and medicine. Over the last decade, the most widely exploited application is their thermal decomposition to afford copper sulfides, the size, phase and morphology of which can be tuned via judicious choice of reaction conditions. This approach has been further extended to the synthesis of technologically important ternary and quaternary sulfides, most notably $\mathrm{Cu}_{2} \mathrm{ZnSnS}_{4}$ (CZTS), which results from the co-decomposition of copper, zinc and tin dithiocarbamates. Another important development is the realisation that $\left[\mathrm{Cu}\left(\mathrm{S}_{2} \mathrm{CNEt}_{2}\right)_{2}\right]$ is formed in the biological domain when the anti-alcohol drug disulfiram is taken, and that it shows anticancer behaviour, leading to detailed investigation of the biological role of $\mathrm{Cu}$ (II) bis(dithiocarbamates). While still not fully understood, there is strong evidence that it functions as a proteasome inhibitor, specifically targeting the 
ubiquitin-proteasome pathway and inducing apoptosis. A major problem with using $\left[\mathrm{Cu}\left(\mathrm{S}_{2} \mathrm{CNEt}_{2}\right)_{2}\right]$ and most other derivatives as drugs is their extremely low water solubility, and this is being addressed using a Trojan Horse strategy to deliver $\left[\mathrm{Cu}\left(\mathrm{S}_{2} \mathrm{CNEt}_{2}\right)_{2}\right]$ or to generate it in situ within the cell from reaction between $\mathrm{Cu}$ (II) ions and disulfiram. Thus, an "old" molecule finds new relevance bringing an "old" branch of coordination chemistry back to life. In doing the latter, over the past decade, a wide range of novel new $\mathrm{Cu}(\mathrm{I})$ dithiocarbamate clusters have been discovered. Their structures are novel, with some being in the nanoscale domain, and understanding how to control their specific size and shape, for example by using different dithiocarbamate substituents and/or other ancillary ligands to generate bespoke clusters in high yields, remains an exciting challenge. Given the widespread development of simple $\mathrm{Cu}$ (II) and $\mathrm{Cu}(\mathrm{I})$ complexes as SSPs to nanoscale copper sulfides, these clusters might be viewed as intermediates in this process or could be potential SSPs themselves, an area that appears to be totally unexplored to date. We look forward to these exciting new developments and hope that in 10-20 years a researcher scanning this review will find it useful background reading but quite out of date since the field will have moved on enormously.

Author Contributions: Conceptualisation, writing-original draft preparation, review, and editing, G.H.; Writing—original draft preparation, review, and editing, D.C.O. All authors have read and agreed to the published version of the manuscript.

Funding: This research received no external funding.

Acknowledgments: We thank King's College London and North-West University for support of the authors work and the Royal Society of Chemistry for the award of a travel grant to D.C.O. to enable him to visit King's College.

Conflicts of Interest: The authors declare no conflict of interest.

\section{References}

1. Havlík, T. Chapter 3-Phase Equilibrium of Copper Iron Sulphides. In Hydrometallurgy; Havlík, T., Ed.; Woodhead Publishing: Sawston, UK, 2008; pp. 29-59.

2. Mathys, Z.K.; White, A.R. Copper and Alzheimer's disease. In Neurotoxicity of Metals; Springer: Berlin/Heidelberg, Germany, 2017; pp. 199-216.

3. Hogarth, G. Transition metal dithiocarbamates: 1978-2003. Prog. Inorg. Chem. 2005, 53, 71-561.

4. Heard, P.J. Main group dithiocarbamate complexes. Prog. Inorg. Chem. 2005, 53, 1-69.

5. Delépine, M. Experiments on Copper and Iron. Bull. Société Chim. Fr. 1908, 3, 652-654.

6. Delépine, M. Properties of the Metallic Salts of Dithiocarbamic Acid. Comptes Rendus 1908, 146, 981-985.

7. Ngo, S.C.; Banger, K.K.; DelaRosa, M.J.; Toscano, P.J.; Welch, J.T. Thermal and structural characterization of a series of homoleptic $\mathrm{Cu}(\mathrm{II})$ dialkyldithiocarbamate complexes: Bigger is only marginally better for potential MOCVD performance. Polyhedron 2003, 22, 1575-1583. [CrossRef]

8. Jian, F.; Wang, Z.; Bai, Z.; You, X.; Fun, H.-K.; Chinnakali, K.; Razak, I.A. The crystal structure, equilibrium and spectroscopic studies of bis(dialkyldithiocarbamate) copper(II) complexes $\left[\mathrm{Cu}_{2}\left(\mathrm{R}_{2} \mathrm{dtc}\right)_{4}\right]$ (dtc=dithiocarbamate). Polyhedron 1999, 18, $3401-3406$. [CrossRef]

9. Monser, L.; Adhoum, N. Modified activated carbon for the removal of copper, zinc, chromium and cyanide from wastewater. Sep. Purif. Technol. 2002, 26, 137-146. [CrossRef]

10. Bai, L.; Hu, H.; Fu, W.; Wan, J.; Cheng, X.; Zhuge, L.; Xiong, L.; Chen, Q. Synthesis of a novel silica-supported dithiocarbamate adsorbent and its properties for the removal of heavy metal ions. J. Hazard. Mater. 2011, 195, 261-275. [CrossRef]

11. Gallagher, W.P.; Vo, A. Dithiocarbamates: Reagents for the removal of transition metals from organic reaction media. Org. Process. Res. Dev. 2015, 19, 1369-1373. [CrossRef]

12. Casey, A.T.; Vecchio, A.M. The electrochemical synthesis of ethylxanthate and dimethyldithiocarbamate complexes of iron, cobalt, nickel and copper. J. Coord. Chem. 1988, 16, 375-381. [CrossRef]

13. Victoriano, L.I. The reaction of copper and iron species with thiuram sulfides: Copper and iron dithiocarbamate derivatives. Polyhedron 2000, 19, 2269-2275. [CrossRef]

14. Ferreira, I.P.; de Lima, G.M.; Paniago, E.B.; Takahashi, J.A.; Krambrock, K.; Pinheiro, C.B.; Wardell, J.L.; Visentin, L.C. Synthesis, characterization, structural and biological aspects of copper(II) dithiocarbamate complexes-Part II, $\left[\mathrm{Cu}\left\{\mathrm{S}_{2} \mathrm{CN}(\mathrm{Me})\left(\mathrm{R}^{1}\right)\right\}_{2}\right], \quad\left[\mathrm{Cu}\left\{\mathrm{S}_{2} \mathrm{CN}(\mathrm{Me})\left(\mathrm{R}^{2}\right)\right\}_{2}\right]$ and $\left[\mathrm{Cu}\left\{\mathrm{S}_{2} \mathrm{CN}\left(\mathrm{R}^{3}\right)\left(\mathrm{R}^{4}\right)\right\}_{2}\right] \quad\left\{\mathrm{R}^{1}=\mathrm{CH}_{2} \mathrm{CH}(\mathrm{OMe})_{2}, \mathrm{R}^{2}=2\right.$-methyl-1,3-dioxolane, $\mathrm{R}^{3}=\mathrm{CH}_{2}\left(\mathrm{CH}_{2}\right)_{2} \mathrm{NCHPhOCH}_{2} \mathrm{Ph}$ and $\mathrm{R}^{4}=\mathrm{CH}_{2} \mathrm{CH}_{2} \mathrm{OH}$. J. Mol. Struct. 2013, 1048, 357-366. 
15. Anastasiadis, C.; Hogarth, G.; Wilton-Ely, J.D.E.T. Functionalised dithiocarbamate complexes: Complexes based on indoline, indole and substituted piperazine backbones-X-ray crystal structure of $\left[\mathrm{Ni}\left(\mathrm{S}_{2} \mathrm{CNC}_{3} \mathrm{H}_{6} \mathrm{C}_{6} \mathrm{H}_{4}\right)_{2}\right]$. Inorg. Chim. Acta 2010, 363, 3222-3228. [CrossRef]

16. De Lima, G.M.; Menezes, D.C.; Cavalcanti, C.A.; dos Santos, J.A.F.; Ferreira, I.P.; Paniago, E.B.; Wardell, J.L.; Wardell, S.M.S.V.; Krambrock, K.; Mendes, I.C.; et al. Synthesis, characterisation and biological aspects of copper(II) dithiocarbamate complexes, $\left[\mathrm{Cu}\left\{\mathrm{S}_{2} \mathrm{CNR}\left(\mathrm{CH}_{2} \mathrm{CH}_{2} \mathrm{OH}\right)\right\}_{2}\right],\left(\mathrm{R}=\mathrm{Me}, \mathrm{Et}, \mathrm{Pr}\right.$ and $\left.\mathrm{CH}_{2} \mathrm{CH}_{2} \mathrm{OH}\right)$. J. Mol. Struct. 2011, 988, 1-8. [CrossRef]

17. Gupta, A.; Singh, V.; Kumar, V.; Rajput, A.; Singh, L.; Drew, M.; Singh, N. Syntheses, crystal structures and conducting properties of new homoleptic copper (II) dithiocarbamate complexes. Inorg. Chim. Acta 2013, 408, 145-151. [CrossRef]

18. Gurumoorthy, G.; Thirumaran, S.; Ciattini, S. Synthesis and characterization of copper(II) dithiocarbamate complexes involving pyrrole and ferrocenyl moieties and their utility for sensing anions and preparation of copper sulfide and copper-iron sulfide nanoparticles. Appl. Organomet. Chem. 2018, 32, e4363. [CrossRef]

19. Hayat, F.; Faryad Ali, R.; Rehman, Z.u.; Bélanger-Gariepy, F. Molecular, supramolecular, DNA-binding and biological studies of piperazine and piperidine based dithiocarbamates of biocompatible copper. Inorg. Chem. Commun. 2020, 121, 108190. [CrossRef]

20. Macías, B.; Villa, M.a.V.; Chicote, E.; Martín-Velasco, S.; Castiñeiras, A.; Borrás, J.N. Copper complexes with dithiocarbamates derived from natural occurring amino acids. Crystal and molecular structure of $\left[\mathrm{Cu}(\mathrm{en})(\mathrm{EtOH})\left(\mathrm{H}_{2} \mathrm{O}\right)_{3}\right]\left[\mathrm{Cu}(\mathrm{dtc}-\mathrm{pro})_{2}\right]$. Polyhedron 2002, 21, 1899-1904. [CrossRef]

21. Manar, K.K.; Neetu; Kumari, K.; Anamika; Yadav, C.L.; Srivastava, P.; Drew, M.G.B.; Singh, N. Preparation, Characterization and Photosensitizing Activities of Homoleptic Cu(II) Dithiocarbamates in $\mathrm{TiO}_{2}$-Based DSSC. ChemistrySelect 2019, 4, 11140-11148. [CrossRef]

22. Ekennia, A.C.; Onwudiwe, D.C.; Osowole, A.A. Spectral, thermal stability and antibacterial studies of copper, nickel and cobalt complexes of N-methyl-N-phenyl dithiocarbamate. J. Sulfur Chem. 2015, 36, 96-104. [CrossRef]

23. Martin, J.; Newman, P.; Robinson, B.; White, A. Crystal structures of bis-(N-methyl-N-phenyldithiocarbamato)-nickel-(II) and-copper (II). J. Chem. Soc. Dalton Trans. 1972, 2233-2238. [CrossRef]

24. Onwudiwe, D.C.; Ekennia, A.C. Synthesis, characterization, thermal, antimicrobial and antioxidant studies of some transition metal dithiocarbamates. Res. Chem. Intermed. 2017, 43, 1465-1485. [CrossRef]

25. Sarker, J.C.; Hogarth, G. Diaryldithiocarbamate Complexes and Their Use as Single Source Precursors. King's College: London, UK, Unpublished work. 2021.

26. Granell, J.; Green, M.L.H.; Lowe, V.J.; Marder, S.R.; Mountford, P.; Saunders, G.C.; Walker, N.M. Studies on the synthesis and electrochemistry of crown ether dithiocarbamates and the molecular dynamics of bis(aza-15-crown-5)thiuram disulphide. Crystal structure of cobalt tris[(aza-15-crown-5)dithiocarbamate]. J. Chem. Soc. Dalton Trans. 1990, 605-614. [CrossRef]

27. Mnqiwu, K.; Xaba, T.; Moloto, M.J.; Mubiayi, P.K.; Nyamukamba, P.; Sibokoza, S.B. Plasmonic electron deficient Cu2-xS semiconductor nanoparticles from cyclohexylamine-N-dithiocarbamate ligand. Mater. Lett. 2017, 199, 28-31. [CrossRef]

28. Kaushik, N.K.; Bhushan, B.; Sharma, A.K. Bis [n(chlorophenyl) dithiocarbamato] complexes of Cu(II), Zn(II), Cd(II) and Sn(II). Thermochim. Acta 1984, 76, 345-357. [CrossRef]

29. Muthuswamy, S.; Venkappayya, D. A study on the thermal-decomposition of some metal dithiocarbamate complexes. J. Ind. Chem. Soc. 1987, 64, 571-573.

30. Cachapa, A.; Mederos, A.; Gili, P.; Hernández-Molina, R.; Domínguez, S.; Chinea, E.; Rodríguez, M.L.; Feliz, M.; Llusar, R.; Brito, F. Studies of the interaction between bis (dithiocarbamato) copper(II) complexes with nitric oxide in aqueous solution and biological applications. Polyhedron 2006, 25, 3366-3378. [CrossRef]

31. Mann, P.B.; McGregor, I.J.; Bourke, S.; Burkitt-Gray, M.; Fairclough, S.; Ma, M.T.; Hogarth, G.; Thanou, M.; Long, N.; Green, M. An atom efficient, single-source precursor route to plasmonic CuS nanocrystals. Nanoscale Adv. 2019, 1, 522-526. [CrossRef]

32. Beer, P.D.; Berry, N.; Drew, M.G.; Fox, O.D.; Padilla-Tosta, M.E.; Patell, S. Self-assembled dithiocarbamate-copper (II) macrocycles for electrochemical anion recognition. Chem. Commun. 2001, 199-200. [CrossRef]

33. Berry, N.G.; Shimell, T.W.; Beer, P.D. Heteroditopic transition metal dithiocarbamate receptors for binding cation-anion ion pairs. J. Supramol. Chem. 2002, 2, 89-92. [CrossRef]

34. Cookson, J.; Evans, E.A.; Maher, J.P.; Serpell, C.J.; Paul, R.L.; Cowley, A.R.; Drew, M.G.; Beer, P.D. Metal-directed assembly of large dinuclear copper (II) dithiocarbamate macrocyclic complexes. Inorg. Chim. Acta 2010, 363, 1195-1203. [CrossRef]

35. Cao, R., Jr.; Díaz, A.; Cao, R.; Otero, A.; Cea, R.; Rodríguez-Argüelles, M.C.; Serra, C. Building layer-by-layer a bis(dithiocarbamato)copper(II) complex on Au[111] surfaces. J. Am. Chem. Soc. 2007, 129, 6927-6930. [CrossRef]

36. Brustolin, L.; Nardon, C.; Pettenuzzo, N.; Fantoni, N.Z.; Quarta, S.; Chiara, F.; Gambalunga, A.; Trevisan, A.; Marchio, L.; Pontisso, P. Synthesis, chemical characterization and cancer cell growth-inhibitory activities of $\mathrm{Cu}(\mathrm{II})$ and $\mathrm{Ru}(\mathrm{III})$ aliphatic and aromatic dithiocarbamato complexes. Dalton Trans. 2018, 47, 15477-15486. [CrossRef]

37. Pettenuzzo, N.; Brustolin, L.; Coltri, E.; Gambalunga, A.; Chiara, F.; Trevisan, A.; Biondi, B.; Nardon, C.; Fregona, D. CuII and AuIII Complexes with Glycoconjugated Dithiocarbamato Ligands for Potential Applications in Targeted Chemotherapy. ChemMedChem 2019, 14, 1162-1172. [CrossRef]

38. Torres Martin de Rosales, R.; Tavaré, R.; Paul, R.L.; Jauregui-Osoro, M.; Protti, A.; Glaria, A.; Varma, G.; Szanda, I.; Blower, P.J. Synthesis of 64CuII-Bis(dithiocarbamatebisphosphonate) and Its Conjugation with Superparamagnetic Iron Oxide Nanoparticles: In Vivo Evaluation as Dual-Modality PET-MRI Agent. Angew. Chem. Int. Ed. 2011, 50, 5509-5513. [CrossRef] 
39. Wilton-Ely, J.D.E.T.; Solanki, D.; Knight, E.R.; Holt, K.B.; Thompson, A.L.; Hogarth, G. Multimetallic Assemblies Using PiperazineBased Dithiocarbamate Building Blocks. Inorg. Chem. 2008, 47, 9642-9653. [CrossRef] [PubMed]

40. Akerström, S.; Lindahl, P.B. A convenient method for determination of tetramethylthiuram disulphide. Acta Chem. Scand. 1962, 16, 1206-1211. [CrossRef]

41. Cao, R., Jr.; Villalonga, R.; Díaz-García, A.M.; Cao, R.; Rojo, T.; Rodríguez-Argüelles, M.C. Gold Nanoparticles Enhancing Dismutation of Superoxide Radical by Its Bis(dithiocarbamato)copper(II) Shell. Inorg. Chem. 2011, 50, 4705-4712. [CrossRef]

42. Konarev, D.V.; Kovalevsky, A.Y.; Khasanov, S.S.; Saito, G.; Lopatin, D.V.; Umrikhin, A.V.; Otsuka, A.; Lyubovskaya, R.N. Synthesis, crystal structures, magnetic properties and photoconductivity of $\mathrm{C} 60$ and C70 complexes with metal dialkyldithiocarbamates $\mathrm{M}$ (R2dtc) $\mathrm{x}$, where $\mathrm{M}=\mathrm{Cu}^{\mathrm{II}}, \mathrm{Cu}^{\mathrm{I}}, \mathrm{Ag}^{\mathrm{I}}, \mathrm{Zn}^{\mathrm{II}}, \mathrm{Cd}^{\mathrm{II}}, \mathrm{Hg}^{\mathrm{II}}, \mathrm{Mn}^{\mathrm{II}}, \mathrm{Ni}^{\mathrm{II}}$, and $\mathrm{Pt}^{\mathrm{II}} ; \mathrm{R}=\mathrm{Me}, \mathrm{Et}$, and ${ }^{\mathrm{n}}$ Pr. Eur. J. Inorg. Chem. 2006, 1881-1895. [CrossRef]

43. Hagen, K.; Holwill, C.J.; Rice, D.A. Gas-phase electron diffraction study of bis (dimethyldithiocarbamato) copper (II), $\left[\mathrm{Cu}\left(\mathrm{S}_{2} \mathrm{CNMe}_{2}\right)_{2}\right]$, and bis (dimethyldithiocarbamato) zinc (II), $\left[\mathrm{Zn}\left(\mathrm{S}_{2} \mathrm{CNMe}\right)_{2}\right]$. Inorg. Chem. 1989, 28, 3239-3242. [CrossRef]

44. Einstein, F.; Field, J. Copper (II) bis (N, N-dimethyldithiocarbamate). Acta Crystallogr. Sect. B Struct. Crystallogr. Cryst. Chem. 1974, 30, 2928-2930. [CrossRef]

45. Boyd, P.D.; Mitra, S.; Raston, C.L.; Rowbottom, G.L.; White, A.H. Magnetic and structural studies on copper (II) dialkyldithiocarbamates. J. Chem. Soc. Dalton Trans. 1981, 13-22. [CrossRef]

46. Hatfield, W.E.; Singh, P.; Nepveu, F. Structure and magnetic properties of bis (N, N-diisopropyldithiocarbamato) copper (II). Inorg. Chem. 1990, 29, 4214-4217. [CrossRef]

47. Hogarth, G.; Faulkner, S. The crystal structure of $\left[\mathrm{Cu}\left(\mathrm{S}_{2} \mathrm{CNC}_{4} \mathrm{H}_{8} \mathrm{O}\right)_{2}\right]$ : An interesting structural motif constructed by intermolecular S. . S and C-H . . Cu interactions. Inorg. Chim. Acta 2013, 408, 222-224. [CrossRef]

48. Nieke, C.; Reinhold, J. NDDO study of the coordination structure of $\mathrm{M}\left(\mathrm{S}_{2} \mathrm{CNH}_{2}\right)_{2}$ complexes $(\mathrm{M}=\mathrm{Ni}, \mathrm{Cu})$. J. Mol. Struct. 1986, 139, 241-245. [CrossRef]

49. Tiekink, E.R. The remarkable propensity for the formation of $\mathrm{C}-\mathrm{H} \cdots \pi$ (chelate ring) interactions in the crystals of the firstrow transition metal dithiocarbamates and the supramolecular architectures they sustain. CrystEngComm 2020, 22, 7308-7333. [CrossRef]

50. Konarev, D.V.; Kovalevsky, A.Y.; Lopatin, D.V.; Umrikhin, A.V.; Yudanova, E.I.; Coppens, P.; Lyubovskaya, R.N.; Saito, G. Synthesis, crystal structure and photoconductivity of the first [60]fullerene complex with metal diethyldithiocarbamate: $\left\{\mathrm{Cu}(\mathrm{dedtc})_{2}\right\}_{2} \cdot \mathrm{C}_{60}$. Dalton Trans. 2005, 1821-1825. [CrossRef]

51. Konarev, D.V.; Kovalevsky, A.Y.; Otsuka, A.; Saito, G.; Lyubovskaya, R.N. Neutral and Ionic Complexes of $\mathrm{C}_{60}$ with Metal Dibenzyldithiocarbamates. Reversible Dimerization of C60•-in Ionic Multicomponent Complex $\left[\mathrm{CrI}\left(\mathrm{C}_{6} \mathrm{H}_{6}\right)^{2 \bullet+}\right] \odot\left(\mathrm{C}_{60} \bullet-\right) \odot 0.5$ [Pd(dbdtc) $)_{2}$ ]. Inorg. Chem. 2005, 44, 9547-9553. [CrossRef]

52. Fox, O.D.; Cookson, J.; Wilkinson, E.J.; Drew, M.G.; MacLean, E.J.; Teat, S.J.; Beer, P.D. Nanosized polymetallic resorcinarene-based host assemblies that strongly bind fullerenes. J. Am. Chem. Soc. 2006, 128, 6990-7002. [CrossRef] [PubMed]

53. Newton, W.J.; Tabner, B.J. Electron spin resonance study of some copper(II) dithiocarbamates and their mixed-ligand complexes. J. Chem. Soc. Dalton Trans. 1981, 466-471. [CrossRef]

54. Weeks, M.; Fackler, J.P. Single-crystal electron paramagnetic resonance studies of copper diethyldithiocarbamate. Inorg. Chem. 1968, 7, 2548-2553. [CrossRef]

55. Yordanov, N.D.; Dimitrova, A. Solvent effect on the ligand exchange between bis (diethyldithiocarbamato) copper (II) and bis (diethyldiselenocarbamato) copper (II). Z. Für Anorg. Und Allg. Chem. 2005, 631, 956-960. [CrossRef]

56. Jeliazkova, B.; Dimitrova, A.; Yordanov, N. Charge-transfer photochemistry of the ternary complex (dithio-diseleno-carbamato) copper (II). Spectrochim. Acta Part A Mol. Biomol. Spectrosc. 2002, 58, 1163-1170. [CrossRef]

57. Geurts, P.; Bouten, P.; Van der Avoird, A. Hartree-Fock-Slater-LCAO calculations on the Cu(II) bis (dithiocarbamate) complex; Magnetic coupling parameters and optical spectrum. J. Chem. Phys. 1980, 73, 1306-1312. [CrossRef]

58. Suzuki, Y.; Fujii, S.; Tominaga, T.; Yoshimoto, T.; Yoshimura, T.; Kamada, H. The origin of an EPR signal observed in dithiocarbamate-loaded tissues: Copper (II)-dithiocarbamate complexes account for the narrow hyperfine lines. Biochim. Biophys. Acta Gen. Subj. 1997, 1335, 242-245. [CrossRef]

59. Cvek, B. Targeting malignancies with disulfiram (Antabuse): Multidrug resistance, angiogenesis, and proteasome. Curr. Cancer Drug Targets 2011, 11, 332-337. [CrossRef]

60. Hogarth, G. Metal-dithiocarbamate complexes: Chemistry and biological activity. Mini Rev. Med. Chem. 2012, 12, 1202-1215. [CrossRef]

61. Skrott, Z.; Cvek, B. Diethyldithiocarbamate complex with copper: The mechanism of action in cancer cells. Mini Rev. Med. Chem. 2012, 12, 1184-1192. [CrossRef]

62. Skrott, Z.; Mistrik, M.; Andersen, K.K.; Friis, S.; Majera, D.; Gursky, J.; Ozdian, T.; Bartkova, J.; Turi, Z.; Moudry, P. Alcohol-abuse drug disulfiram targets cancer via p97 segregase adaptor NPL4. Nature 2017, 552, 194-199. [CrossRef]

63. Zhao, Z.; Fan, J.; Deng, X.; Liu, J. One-step synthesis of phosphorus-doped $g-\mathrm{C}_{3} \mathrm{~N}_{4} / \mathrm{Co}_{3} \mathrm{O}_{4}$ quantum dots from vitamin B12 with enhanced visible-light photocatalytic activity for metronidazole degradation. Chem. Eng. J. 2019, 360, 1517-1529. [CrossRef]

64. Larionov, S.; Kosareva, L.; Malikova, A.; Shklyaev, A. Thermal-properties of copper (II) complexes with dithiocarbamic acidderivatives. Zhurnal Neorg. Khimii 1977, 22, 2401-2406. 
65. Hendrickson, A.; Martin, R.; Rohde, N. Dithiocarbamates of copper (I), copper (II), and copper (III). An electrochemical study. Inorg. Chem. 1976, 15, 2115-2119. [CrossRef]

66. Furneaux, R.H.; Sinn, E. Antiferromagnetic copper (II) halide adducts of copper (II) dithiocarbamates. Inorg. Chem. 1977, 16, 1809-1812. [CrossRef]

67. Sarova, G.H.; Jeliazkova, B.G. Effect of solvent and remote ligand substituents on the photochemical behaviour of copper (II) dithiocarbamates and dithiophosphates. Transit. Met. Chem. 2001, 26, 388-394. [CrossRef]

68. Golding, R.; Rae, A.; Sulligoi, L. New series of polynuclear copper dithiocarbamate-copper halide polymers. Inorg. Chem. 1974, 13, 2499-2504. [CrossRef]

69. Jeliazkova, B.; Doicheva, M. Charge-transfer photochemistry of copper(II) dithiocarbamate mixed-ligand complexes. Polyhedron 1996, 15, 1277-1282. [CrossRef]

70. Plyusnin, V.F.; Kolomeets, A.V.; Grivin, V.P.; Larionov, S.V.; Lemmetyinen, H. Photochemistry of dithiocarbamate Cu(II) complex in CCl4. J. Phys. Chem. A 2011, 115, 1763-1773. [CrossRef] [PubMed]

71. Ivanov, A.V.; Lutsenko, I.; Forsling, W. Bis (dimethyldithiocarbamato)(pyridine) zinc and-copper (II) and Their Benzene Solvates: EPR and Solid-State Natural Abundance $\left({ }^{13} \mathrm{C},{ }^{15} \mathrm{~N}\right) \mathrm{CP} / \mathrm{MAS}$ NMR. Russ. J. Coord. Chem. 2002, 28, 57-63. [CrossRef]

72. Díaz, A.; Ortiz, M.; Sánchez, I.; Cao, R.; Mederos, A.; Sanchiz, J.; Brito, F. Interactions of nitric oxide with copper (II) dithiocarbamates in aqueous solution. J. Inorg. Biochem. 2003, 95, 283-290. [CrossRef]

73. Mederos, A.; Cachapa, A.; Hernández-Molina, R.; Armas, M.T.; Gili, P.; Sokolov, M.; González-Platas, J.; Brito, F. Theoretical and spectrophotometrical study of the interaction of nitric oxide with copper (II) dithiocarbamates. Inorg. Chem. Commun. 2003, 6, 498-502. [CrossRef]

74. Hogarth, G.; Holman, K.T.; Pateman, A.; Sella, A.; Steed, J.W.; Richards, I. Multiple nitrene insertions into metal-sulfur bonds of dithiocarbamate complexes: Synthesis of sulfido-amido and zwitterionic tetraamido complexes. Dalton Trans. 2005, $2688-2695$. [CrossRef]

75. Hogarth, G.; Pateman, A.; Sella, A. Multiple nitrene insertions into the copper-sulfur bonds ofdithiocarbamate ligands: Synthesis and molecular structure of thetetraamido complex $\left[\mathrm{Cu}\left\{\eta^{2}-\mathrm{RNSC}\left(\mathrm{NMe}_{2}\right) \mathrm{SNR}\right\}_{2}\right]\left(\mathrm{R}=\mathrm{SO}_{2} \mathrm{C} \mathrm{H}_{4} \mathrm{Me}-\mathrm{p}\right)$. Chem. Commun. 1997, 1029-1030. [CrossRef]

76. Melník, M.; Kabešová, M. Copper (III) coordination compounds: Classification and analysis of crystallographic and structural data. J. Coord. Chem. 2000, 50, 323-338. [CrossRef]

77. DiMucci, I.M.; Lukens, J.T.; Chatterjee, S.; Carsch, K.M.; Titus, C.J.; Lee, S.J.; Nordlund, D.; Betley, T.A.; MacMillan, S.N.; Lancaster, K.M. The myth of $\mathrm{d}^{8}$ copper (III). J. Am. Chem. Soc. 2019, 141, 18508-18520. [CrossRef] [PubMed]

78. Ainscough, E.W.; Brodie, A.M. Sulphur-ligand-metal complexes. Part 7. The interaction of some diphosphine dichalcogenides and tetra-alkylthiuram disulphides with halogens and some first-row transition-metal salts. J. Chem. Soc. Dalton Trans. 1977, 565-570. [CrossRef]

79. Fox, O.D.; Drew, M.G.; Beer, P.D. Resorcarene-based nanoarchitectures: Metal-directed assembly of a molecular loop and tetrahedron. Angew. Chem. Int. Ed. 2000, 39, 135-140. [CrossRef]

80. Larin, G.; Zvereva, G.; Kozmin, P.; Larina, T.; Surazhskaya, M. Synthesis, structure, and properties of copper (III) bis (N, N-diethyldithiocarbamato) triiodide. Inorg. Mater. 1984, 20, 451-454.

81. Pervukhina, N.; Podberezskaya, N.; Patrina, L.; Larionov, S. Crystal and molecular structure of bis (di-n-propyldithiocarbamato) copper (III) penta-iodide $\mathrm{Cu}\left[\mathrm{S}_{2} \mathrm{CN}\left(\mathrm{C}_{3} \mathrm{H}_{7}\right)_{2}\right]_{2} \mathrm{I}_{5}$. J. Struct. Chem. 1989, 30, 694-697. [CrossRef]

82. Bond, A.M.; Colton, R.; D-Agostino, A.; Harvey, J.; Traeger, J.C. Electrospray mass spectrometric study of the nature and lability of cationic complexes generated by the reaction of solutions of neutral iron (III), cobalt (III), nickel (II) and copper (II) dithiocarbamates with nitrosonium tetrafluoroborate. Inorg. Chem. 1993, 32, 3952-3956. [CrossRef]

83. Jung, S.; Nam, D.; Choe, W. Trivalent copper and indium heterometallic complex with dithiocarbamate and iodide ligands. J. Mol. Struct. 2020, 1204, 127478.

84. Barbier, J.-P. Copper(III) and nickel(III) diethyldithiocarbamates: An example of copper (II) disproportionation. Inorg. Chim. Acta 1983, 77, 117-118. [CrossRef]

85. Farhadi, S.; Dusek, M.; Siadatnasab, F.; Eigner, V. First organic-inorganic hybrid nanomaterial constructed from a Keggintype polyoxometallate and a copper-dithiocarbamate complex: Sonochemical synthesis, crystal structure and its adsorption performance for organic dye pollutants. Polyhedron 2017, 126, 227-238. [CrossRef]

86. Siadatnasab, F.; Farhadi, S.; Dusek, M.; Eigner, V.; Hoseini, A.-A.; Khataee, A. Sonochemical synthesis and structural characterization of an organic-inorganic nanohybrid based on a copper-dithiocarbamate complex and $\mathrm{PMo}_{12} \mathrm{O}_{40}{ }^{3-}$ polyanion as a novel sonocatalyst. Ultrason. Sonochemistry 2020, 64, 104727. [CrossRef] [PubMed]

87. Brown, K. Bis(N-pyrrolidyldithiocarbamato) copper(III) perchlorate $\mathrm{C}_{10} \mathrm{H}_{16} \mathrm{ClCuN}_{2} \mathrm{O}_{4} \mathrm{~S}_{4}$. Cryst. Struct. Commun. 1979, 8 , 157-158.

88. Hogarth, G.; Ebony-Jewel, C.-R.; Richards, I. Functionalised dithiocarbamate complexes: Synthesis and molecular structures of

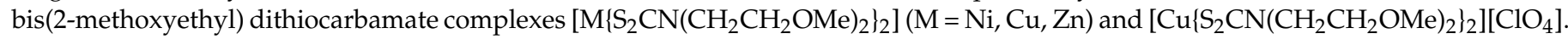
Inorg. Chim. Acta 2009, 362, 1361-1364. [CrossRef]

89. Kaul, B.B.; Pandeya, K. Some Cu(III) dithiocarbamates. J. Inorg. Nucl. Chem. 1981, 43, 1942-1944. [CrossRef]

90. Pandeya, K.; Waraich, T.; Gaur, R.; Singh, R. Synthesis and Characterisation of Some Bis(dithiocarbamato) copper(III) Perchlorate Complexes. Synth. React. Inorg. Met. Org. Chem. 1982, 12, 493-500. [CrossRef] 
91. Hogarth, G.; Pateman, A.; Redmond, S.P. Crystal structures of copper(III) dithiocarbamate complexes $\left[\mathrm{Cu}\left(\mathrm{k}^{2}-\mathrm{S}_{2} \mathrm{CNMe}_{2}\right)_{2}\right]\left[\mathrm{ClO} \mathrm{O}_{4}\right]$ and $\left[\mathrm{Cu}\left(\mathrm{k}^{2}-\mathrm{S}_{2} \mathrm{CNEt}_{2}\right)_{2}\right]\left[\mathrm{FeCl}_{4}\right]$ with and without anion-cation interactions. Inorg. Chim. Acta 2000, 306, 232-236. [CrossRef]

92. Shtyrlin, V.G.; Zakharov, A.V.; Kuznetsov, A.M.; Kukushkina, O.G.V.; Chernov, P.P. Thermodynamics of Redox Processes and Kinetics and Mechanism of Electron Self-Exchange Reactions in the Bis(N,N-diethyldithiocarbamato) copper (II)/Iodine/Dichloromethane System. Eur. J. Inorg. Chem. 2002, 2002, 2947-2955. [CrossRef]

93. Yusuff, K.M.; Mathew, E. Reaction of Thionyl Chloride with bis(dithiocarbamato)-Copper(II) Complexes. Synth. React. Inorg. Met. Org. Nano-Met. Chem. 1992, 22, 575-583. [CrossRef]

94. Victoriano, L.I. Copper (III) Dithiocarbamates. An Undergraduate Experimental Project with Unexpected Challenges. J. Chem. Educ. 2002, 79, 1252-1253. [CrossRef]

95. Beurskens, P.; Cras, J.; Steggerda, J.J. Structure and properties of dibromo-N, N-dibutyldithiocarbamato complexes of copper (III) and gold (III). Inorg. Chem. 1968, 7, 810-813. [CrossRef]

96. Willert-Porada, M.A.; Burton, D.J.; Baenziger, N.C. Synthesis and X-ray structure of bis (trifluoromethyl)(N, N-diethyldithiocarbamato)copper; a remarkably stable perfluoroalkylcopper (III) complex. J. Chem. Soc. Chem. Commun. 1989, 1633-1634. [CrossRef]

97. Naumann, D.; Roy, T.; Caeners, B.; Hutten, D.; Tebbe, K.; Gilles, T. Syntheses and properties of pentafluoroethylcopper (I) and-copper (III) compounds. Z. Fur Anorg. Und Allg. Chem. 2000, 626, 999-1003. [CrossRef]

98. Hesse, R. Crystal structure of copper (I) diethyldithiocarbamate and its interpretation-an application of chemical topology. Ark. Kemi 1963, 20, 481.

99. Nguyen, L.M.; Dellinger, M.E.; Lee, J.T.; Quinlan, R.A.; Rheingold, A.L.; Pike, R.D. Convenient synthesis of copper (I) thiolates and related compounds. Inorg. Chim. Acta 2005, 358, 1331-1336. [CrossRef]

100. Cardell, D.; Hogarth, G.; Faulkner, S. A dithiocarbamate-stabilized copper (I) cube. Inorg. Chim. Acta 2006, 359, 1321-1324. [CrossRef]

101. Victoriano, L.I.; Cortés, H.B. Cuprous dithiocarbamates. Syntheses and reactivity. J. Coord. Chem. 1996, 39, 231-239. [CrossRef]

102. Victoriano, L.I.; Cortés, H.B.; Yuseff, M.I.S.; Fuentealba, L.C. Copper (III) dithiocarbamate complexes from thiuram disulfides and copper (I) halides. J. Coord. Chem. 1996, 39, 241-251. [CrossRef]

103. Lane, A.C.; Vollmer, M.V.; Laber, C.H.; Melgarejo, D.Y.; Chiarella, G.M.; Fackler Jr, J.P.; Yang, X.; Baker, G.A.; Walensky, J.R. Multinuclear copper (I) and silver (I) amidinate complexes: Synthesis, luminescence, and $\mathrm{CS}_{2}$ insertion reactivity. Inorg. Chem. 2014, 53, 11357-11366. [CrossRef] [PubMed]

104. Kita, H.; Miyake, S.-i.; Tanaka, K.; Tanaka, T. Kinetics and Mechanism of the Oxidation Reactions of Dialkyldithiocarbamatocopper (I) Tetramer and-silver (I) Hexamer with Tetraalkylthiuram Disulfide. Bull. Chem. Soc. Jpn. 1979, 52, 3532-3538. [CrossRef]

105. Chakrahari, K.K.; Silalahi, R.P.B.; Chiu, T.H.; Wang, X.; Azrou, N.; Kahlal, S.; Liu, Y.C.; Chiang, M.H.; Saillard, J.Y.; Liu, C. Synthesis of Bimetallic Copper-Rich Nanoclusters Encapsulating a Linear Palladium Dihydride Unit. Angew. Chem. 2019, 131, 4997-5001. [CrossRef]

106. Edwards, A.J.; Dhayal, R.S.; Liao, P.K.; Liao, J.H.; Chiang, M.H.; Piltz, R.O.; Kahlal, S.; Saillard, J.Y.; Liu, C. Chinese puzzle molecule: A 15 hydride, 28 copper atom nanoball. Angew. Chem. 2014, 126, 7342-7346. [CrossRef]

107. Kishore, P.V.; Liao, J.-H.; Hou, H.-N.; Lin, Y.-R.; Liu, C. Ferrocene-functionalized Cu(I)/ Ag(I) dithiocarbamate clusters. Inorg. Chem. 2016, 55, 3663-3673. [CrossRef] [PubMed]

108. Liao, P.-K.; Fang, C.-S.; Edwards, A.J.; Kahlal, S.; Saillard, J.-Y.; Liu, C. Hydrido copper clusters supported by dithiocarbamates: Oxidative hydride removal and neutron diffraction analysis of $\left[\mathrm{Cu}_{7}(\mathrm{H})\left\{\mathrm{S}_{2} \mathrm{C}(\text { aza-15-crown-5) }\}_{6}\right]\right.$. Inorg. Chem. 2012, 51, 6577-6591. [CrossRef]

109. Chakrahari, K.K.; Liao, J.; Silalahi, R.P.B.; Chiu, T.H.; Liao, J.H.; Wang, X.; Kahlal, S.; Saillard, J.Y.; Liu, C. Isolation and Structural Elucidation of 15-Nuclear Copper Dihydride Clusters: An Intermediate in the Formation of a Two-Electron Copper Superatom. Small 2020, 2002544. [CrossRef] [PubMed]

110. Chakrahari, K.K.; Liao, J.H.; Kahlal, S.; Liu, Y.C.; Chiang, M.H.; Saillard, J.Y.; Liu, C. $\left[\mathrm{Cu}_{13}\left\{\mathrm{~S}_{2} \mathrm{CN}^{\mathrm{n}} \mathrm{Bu}_{2}\right\}_{6}\left(\mathrm{acetylide}_{4}\right]^{+}:\right.$A Two-Electron Superatom. Angew. Chem. 2016, 128, 14924-14928. [CrossRef]

111. Chakrahari, K.K.; Silalahi, R.P.B.; Liao, J.-H.; Kahlal, S.; Liu, Y.-C.; Lee, J.-F.; Chiang, M.-H.; Saillard, J.-Y.; Liu, C. Synthesis and structural characterization of inverse-coordination clusters from a two-electron superatomic copper nanocluster. Chem. Sci. 2018, 9, 6785-6795. [CrossRef] [PubMed]

112. Silalahi, R.P.B.; Chakrahari, K.K.; Liao, J.H.; Kahlal, S.; Liu, Y.C.; Chiang, M.H.; Saillard, J.Y.; Liu, C. Synthesis of Two-Electron Bimetallic $\mathrm{Cu}-\mathrm{Ag}$ and $\mathrm{Cu}-\mathrm{Au}$ Clusters by using $\left[\mathrm{Cu}_{13}\left(\mathrm{~S}_{2} \mathrm{CN}^{\mathrm{n}} \mathrm{Bu}_{2}\right)_{6}(\mathrm{C} \equiv \mathrm{CPh})_{4}\right]^{+}$as a Template. Chem. Asian J. 2018, 13, 500-504. [CrossRef]

113. Silalahi, R.P.B.; Chiu, T.-H.; Kao, J.-H.; Wu, C.-Y.; Yin, C.-W.; Liu, Y.-C.; Chen, Y.J.; Saillard, J.-Y.; Chiang, M.-H.; Liu, C.W. Synthesis and Luminescence Properties of Two-Electron Bimetallic $\mathrm{Cu}-\mathrm{Ag}$ and $\mathrm{Cu}-\mathrm{Au}$ Nanoclusters via Copper Hydride Precursors. Inorg. Chem. 2021, 60, 10799-10807. [CrossRef]

114. Teske, C.L. On Ammonium-bis(dithiocarbamato)-copper(I)-monohydrate and Mono(dithiocarbamato)-copper(I). Z. Für Anorg. Und Allg. Chem. 2013, 639, 2767-2773. [CrossRef]

115. Kowala, C.; Swan, J. Coordination compounds of Group IB metals. III. Triethyl- and triphenylphosphine complexes of cuprous, argentous, and aurous NN-dialkyldithiocarbamates. Aust. J. Chem. 1966, 19, 555-559. [CrossRef]

116. Brinkhoff, H.C.; Matthijssen, A.G.; Oomes, C.G. Triphenylphosphine complexes of Cu(I), Ag(I) and Au(I) N,N-dialkyldithiocarbamates. Inorg. Nucl. Chem. Lett. 1971, 7, 87-89. [CrossRef] 
117. Victoriano, L.; Cortes, H. The reaction of thiuram disulfides and copper metal. Copper (I) dithiocarbamates. Bol. Soc. Chil. Quim. 1996, 41, 27-31.

118. Kumar, A.; Mayer-Figge, H.; Sheldrick, W.S.; Singh, N. Synthesis, Structure, Conductivity, and Calculated Nonlinear Optical Properties of Two Novel Bis(triphenylphosphane)copper(I) Dithiocarbamates. Eur. J. Inorg. Chem. 2009, 2009, $2720-2725$. [CrossRef]

119. Afzaal, M.; Rosenberg, C.L.; Malik, M.A.; White, A.J.P.; O’Brien, P. Phosphine stabilized copper(i) complexes of dithiocarbamates and xanthates and their decomposition pathways. New J. Chem. 2011, 35, 2773-2780. [CrossRef]

120. Shono, T.; Fujii, Y.; Shinra, K. Syntheses of copper (I) triphenylphosphine complexes. Chem. Lett. 1972, 1, 163-164. [CrossRef]

121. $\mathrm{Xu}, \mathrm{L}$. N,N-Bispropyldithiocarbamato Bis (triphenylphosphine) Copper (I) Dichloromethane Solvate:[(n-Pr) $\mathrm{dtc}_{2}(\mathrm{PPh} 3)$ $\left.{ }_{2}\right) \mathrm{Cu} . \mathrm{CH}_{2} \mathrm{Cl}_{2}$, (dtc= Dithiocarbamate). Pol. J. Chem. 2001, 75, 755-757.

122. Rajput, G.; Yadav, M.K.; Drew, M.G.B.; Singh, N. Impact of Ligand Framework on the Crystal Structures and Luminescent Properties of $\mathrm{Cu}(\mathrm{I})$ and $\mathrm{Ag}(\mathrm{I})$ Clusters and a Coordination Polymer Derived from Thiolate/Iodide/dppm Ligands. Inorg. Chem. 2015, 54, 2572-2579. [CrossRef]

123. Kociok-Kohn, G.; Molloy, K.; Sudlow, A. Molecular Routes to $\mathrm{Cu}_{2} \mathrm{ZnSnS}_{4}$ : A Comparison of Approaches to Bulk and Thin-Film Materials. Can. J. Chem. 2014, 92, 514-524. [CrossRef]

124. Gupta, A.N.; Singh, V.; Kumar, V.; Prasad, L.B.; Drew, M.G.B.; Singh, N. Syntheses, crystal structures and optical properties of heteroleptic copper(I) dithio/PPh 3 complexes. Polyhedron 2014, 79, 324-329. [CrossRef]

125. Mothes, R.; Petzold, H.; Jakob, A.; Rüffer, T.; Lang, H. Dithiocarbamate copper(I) and silver(I) complexes: Synthesis, structure and thermal behavior. Inorg. Chim. Acta 2015, 429, 227-236. [CrossRef]

126. Singh, A.K.; Yadav, C.L.; Mishra, K.B.; Singh, S.K.; Gupta, A.N.; Tiwari, V.K.; Drew, M.G.B.; Singh, N. Highly efficient and recyclable pre-catalysts based on mono- and dinuclear heteroleptic $\mathrm{Cu}(\mathrm{I})$ dithio- $\mathrm{PPh}_{3}$ complexes to produce variety of glycoconjugate triazoles. Mol. Catal. 2019, 470, 152-163. [CrossRef]

127. Jamaludin, N.S.; Halim, S.N.A.; Khoo, C.-H.; Chen, B.-J.; See, T.-H.; Sim, J.-H.; Cheah, Y.-K.; Seng, H.-L.; Tiekink, E.R. Bis(phosphane) copper(I) and silver(I) dithiocarbamates: Crystallography and anti-microbial assay. Z. Für Krist. Cryst. Mater. 2016, 231, 341-349. [CrossRef]

128. Huang, T.-H.; Yang, H.; Zhu, S.-L.; Zhao, B.; Yang, Y. Synthesis, structures and fluorescent properties of metal complexes based on polyphosphine ligands. J. Mol. Struct. 2017, 1127, 138-144. [CrossRef]

129. Bianchini, C.; Ghilardi, C.A.; Meli, A.; Midollini, S.; Orlandini, A. Reactivity of copper(I) tetrahydroborates toward carbon disulfide and phenyl isothiocyanate. Structures of $\left(\mathrm{PPh}_{3}\right)_{2} \mathrm{Cu}\left(\mathrm{m}-\mathrm{S}_{2} \mathrm{CSCH}_{2} \mathrm{SCS}_{2}\right) \mathrm{Cu}\left(\mathrm{PPh}_{3}\right)_{2},\left(\mathrm{PPh}_{3}\right)_{2} \mathrm{Cu}\left(\mathrm{S}_{2} \mathrm{COEt}\right)$, and $\left(\mathrm{PPh}_{3}\right)_{2} \mathrm{Cu}\left(\mathrm{S}_{2} \mathrm{CNHPh}\right) \cdot \mathrm{CHCl}_{3}$. Inorg. Chem. 1985, 24, 932-939. [CrossRef]

130. Tan, Y.J.; Yeo, C.I.; Halcovitch, N.R.; Jotani, M.M.; Tiekink, E.R. $\mu^{3}$-Chlorido- $\mu^{2}$-chlorido-( $\mu^{3}$-pyrrolidine-1-carbodithioato$\left.\kappa^{4} \mathrm{~S}: S, \mathrm{~S}^{\prime}: \mathrm{S}^{\prime}\right)$ tris [(triethylphosphane- $\mathrm{P}$ ) copper (I)]: Crystal structure and Hirshfeld surface analysis. Acta Crystallogr. Sect. E Crystallogr. Commun. 2017, 73, 720-725. [CrossRef]

131. Huang, S.-B.; Situ, Y. Synthesis and crystal structure of a dicopper(I) complex with bis(diphenylphosphino)methane and diethyldithiocarbamate. Jiegou Huaxue 2003, 3, 260-264.

132. Langer, R.; Wünsche, L.; Fenske, D.; Fuhr, O. Copper Chalcogenide Cluster Compounds with Bromo-functionalized Ligand Shell. Z. Fuer Anorg. Allg. Chem. 2009, 635, 2488-2494.

133. Okubo, T.; Kawajiri, R.; Mitani, T.; Shimoda, T. A mixed-valence coordination polymer featuring two-dimensional ferroelectric order: $\left\{\left[\mathrm{Cu}(\mathrm{I})_{4} \mathrm{Cu}(\mathrm{II})\left(\mathrm{Et}_{2} \mathrm{dtc}\right)_{2} \mathrm{Cl}_{3}\right]\left[\mathrm{Cu}(\mathrm{II})\left(\mathrm{Et}_{2} \mathrm{dtc}_{2}\right]_{2}\left(\mathrm{FeCl}_{4}\right)\right\} \mathrm{n}\left(\mathrm{Et}_{2} \mathrm{dtc}-=\right.\right.$ diethyldithiocarbamate $)$. J. Am. Chem. Society. 2005, 127, 17598-17599. [CrossRef]

134. Okubo, T.; Tanaka, N.; Kim, K.H.; Anma, H.; Seki, S.; Saeki, A.; Maekawa, M.; Kuroda-Sowa, T. Crystal structure and carrier transport properties of a new 3D mixed-valence $\mathrm{Cu}(\mathrm{I})-\mathrm{Cu}(\mathrm{II})$ coordination polymer including pyrrolidine dithiocarbamate ligand. Dalton Trans. 2011, 40, 2218-2224. [CrossRef]

135. Kawajiri, R.; Okubo, T.; Mitani, T. Structural and magnetic studies on a new mixed-valence $\mathrm{Cu}(\mathrm{I})-\mathrm{Cu}(\mathrm{II})$ octanuclear cluster with a dithiocarbamate derivative. Polyhedron 2006, 25, 2650-2654. [CrossRef]

136. Okubo, T.; Tanaka, N.; Kim, K.H.; Yone, H.; Maekawa, M.; Kuroda-Sowa, T. Magnetic and Conducting Properties of New Halide-Bridged Mixed-Valence CuI-CuII 1D Coordination Polymers Including a Hexamethylene Dithiocarbamate Ligand. Inorg. Chem. 2010, 49, 3700-3702. [CrossRef]

137. Ho, K.K.; Takashi, U.; Takashi, O.; Shinya, H.; Haruho, A.; Kazuya, K.; Tetsuya, S.; Jyunji, F.; Masahiko, M.; Takayoshi, K.-S. Synthesis and Conducting Properties of a New Mixed-valence $\mathrm{Cu}(\mathrm{I})-\mathrm{Cu}(\mathrm{II})$ 1-D Coordination Polymer Bridged by Morpholine Dithiocarbamate. Chem. Lett. 2011, 40, 1184-1186.

138. Okubo, T.; Anma, H.; Tanaka, N.; Himoto, K.; Seki, S.; Saeki, A.; Maekawa, M.; Kuroda-Sowa, T. Crystal structure and carrier transport properties of a new semiconducting 2D coordination polymer with a 3,5-dimethylpiperidine dithiocarbamate ligand. Chem. Commun. 2013, 49, 4316-4318. [CrossRef]

139. Tanaka, N.; Okubo, T.; Anma, H.; Kim, K.H.; Inuzuka, Y.; Maekawa, M.; Kuroda-Sowa, T. Halido-Bridged 1D Mixed-Valence CuI-CuII Coordination Polymers Bearing a Piperidine-1-carbodithioato Ligand: Crystal Structure, Magnetic and Conductive Properties, and Application in Dye-Sensitized Solar Cells. Eur. J. Inorg. Chem. 2013, 2013, 3384-3391. [CrossRef]

140. Okubo, T.; Anma, H.; Maekawa, M.; Kuroda-Sowa, T. Tris([mu]4-azepane-1-carbodithioato)bis([mu]3-azepane-1-carbodithioato)[mu]9-bromido-tetra-[mu]2-bromido-octacopper(I)copper(II). Acta Crystallogr. Sect. E 2013, 69, m275-m276. [CrossRef] [PubMed] 
141. Okubo, T.; Anma, H.; Nakahashi, Y.; Maekawa, M.; Kuroda-Sowa, T. New one-dimensional mixed-valence coordination polymers including an iodine-bridged pentanuclear copper(I) cluster unit. Polyhedron 2014, 69, 103-109. [CrossRef]

142. Nakatani, K.; Himoto, K.; Kono, Y.; Nakahashi, Y.; Anma, H.; Okubo, T.; Maekawa, M.; Kuroda-Sowa, T. Synthesis, Crystal Structure, and Electroconducting Properties of a 1D Mixed-Valence $\mathrm{Cu}(\mathrm{I})-\mathrm{Cu}(\mathrm{II})$ Coordination Polymer with a Dicyclohexyl Dithiocarbamate Ligand. Crystals 2015, 5, 215-225. [CrossRef]

143. Himoto, K.; Suzuki, S.; Okubo, T.; Maekawa, M.; Kuroda-Sowa, T. A new semiconducting 1D Cu(I)-Cu(II) mixed-valence coordination polymer with $\mathrm{Cu}(\mathrm{II})$ dimethylpiperidine-dithiocarbamate and a tetranuclear $\mathrm{Cu}(\mathrm{I})-\mathrm{Br}$ cluster unit. New J. Chem. 2018, 42, 3995-3998. [CrossRef]

144. Mensforth, E.; Hill, M.; Batten, S. Coordination polymers of sulphur-donor ligands. Inorg. Chim. Acta 2013, 403, 9-24. [CrossRef]

145. Cras, J.; Willemse, J.; Gal, A.; Hummelink-Peters, B. Preparation, structure and properties of compounds containing the dipositive tri-copper hexa (N, N-di-n-butyldithiocarbamato) ion, compounds with copper in the oxidation states II and III. Recl. Des Trav. Chim. Des Pays Bas 1973, 92, 641-650. [CrossRef]

146. van de Leemput, P.J.H.A.M.; Cras, J.A.; Willemse, J.; Beurskens, P.T.; Menger, E. Preparation, structure and properties of dicopper tris(N,N-dialkyldithiocarbamato)dihalogeno compounds, $\mathrm{Cu}_{2}\left(\mathrm{R}_{2} \mathrm{dtc}\right)_{3} \mathrm{X}_{2}$, with copper in the oxidation states II and III. Recl. Des Trav. Chim. Des Pays Bas 1976, 95, 191-194. [CrossRef]

147. Cras, J.A.; Willemse, J. Reactions of bisdithiocarbamato $\mathrm{Cu}(\mathrm{II})$ and $\mathrm{Ni}(\mathrm{II})$ with zinc halides. J. Inorg. Nucl. Chem. 1977, 39, 1225-1226. [CrossRef]

148. Spek, A. Bis [bis (,$N$-di-normal-butyldithiocarbamato) copper (III)] bis(dibutyldithiocarbamato) copper (II) tetrabromo-di-mubromo-di-mercurate (II) $\left(-80^{\circ} \mathrm{C}\right), \mathrm{C}_{54} \mathrm{H}_{108} \mathrm{Br}_{6} \mathrm{Cu}_{3} \mathrm{Hg}_{2} \mathrm{~N}_{6} \mathrm{~S}_{12}$. Cryst. Struct. Commun. 1979, 8, 577-582.

149. Hogarth, G.; Faulkner, S. The mixed-valence coordination polymer $\left[\mathrm{Cu}\left(\mathrm{S}_{2} \mathrm{CNPr}_{2}\right)_{2}\right]_{2}\left[\mathrm{ClO}_{4}\right]$ containing alternating square-planar $\mathrm{Cu}(\mathrm{II})$ and $\mathrm{Cu}(\mathrm{III})$ centres. Inorg. Chem. Commun. 2013, 35, 65-68. [CrossRef]

150. Padilla-Tosta, M.E.; Fox, O.D.; Drew, M.G.B.; Beer, P.D. Self-Assembly of a Mixed-Valence Copper(II)/Copper(III) Dithiocarbamate Catenane. Angewadte Chem. Int. Ed. Engl. 2001, 40, 4235-4239. [CrossRef]

151. Okubo, T.; Kuwamoto, H.; Kim, K.H.; Hayami, S.; Yamano, A.; Shiro, M.; Maekawa, M.; Kuroda-Sowa, T. Intervalence ChargeTransfer System by 1D Assembly of New Mixed-Valence Octanuclear CuI/CuII/CuIII Cluster Units. Inorg. Chem. 2011, 50, 2708-2710. [CrossRef]

152. Zhang, Y.; Schröder, K.; Kwak, Y.; Krys, P.; Morin, A.N.; Pintauer, T.; Poli, R.; Matyjaszewski, K. Reversible-Deactivation Radical Polymerization of Methyl Methacrylate and Styrene Mediated by Alkyl Dithiocarbamates and Copper Acetylacetonates. Macromolecules 2013, 46, 5512-5519. [CrossRef]

153. Zhang, Q.; Chen, J.; Hong, M.; Xin, X.; Fun, H.-K. Crystal and molecular structure of the copper (I)-thiolate-selenide complex $\left[\mathrm{Ph}_{4} \mathrm{P}\right]\left[\mathrm{Cu}\left(\mathrm{SeS}_{2} \mathrm{CNC}_{4} \mathrm{H}_{8}\right)\left(\mathrm{S}_{2} \mathrm{CN}_{2} \mathrm{C}_{4} \mathrm{H}_{8}\right)\right]$ with an unusual Se-S bond. Z. Für Nat. B 1999, 54, 1313-1317. [CrossRef]

154. Fan, L.; $\mathrm{Wu}, \mathrm{J}$. Crystal structure of $\left(2,2^{\prime}\right.$-bipyridine- $\left.\kappa^{2} \mathrm{~N}, \mathrm{~N}^{\prime}\right)-\left(\mathrm{N}, \mathrm{N}\right.$-dimethyldithiocarbamato- $\left.\kappa^{2} \mathrm{~S}, \mathrm{~S}^{\prime}\right) \operatorname{copper}(\mathrm{II})$ iodide, $\mathrm{CuI}\left(\mathrm{C}_{10} \mathrm{H}_{8} \mathrm{~N}_{2}\right)\left(\mathrm{C}_{3} \mathrm{H}_{6} \mathrm{NS}_{2}\right)$. Z. Für Krist. New Cryst. Struct. 2010, 225, 347-348. [CrossRef]

155. Fan, L.-Q.; Ji-Hua, W.; Lin, J.; Huang, Y. Synthesis and Crystal Structure of a New Cu(II) Dithiocarbamate Complex CuI(prdtc)(Phen). Chin. J. Struct. Chem. 2009, 28, 580-584.

156. Fan, L.-Q.; Ji-Huai, W.; Yun-Fang, H.; Ng, S. (N,N-Diethyldithiocarbamato-k2S,S')iodido(1,10-phenanthroline-k2N,N')copper(II). Acta Crystallogr. Sect. E 2009, 63, m1209. [CrossRef] [PubMed]

157. Nobuo, O.; Munehiro, T.; Mamiko, O.; Masahiro, Y. Chloro(N,N'-dimethyldithiocarbamato-[kappa]2S,S')(1,10-phenanthroline[kappa]2N,N')copper(II). Acta Crystallogr. Sect. E 2006, 62, m1589-m1591. [CrossRef]

158. Fan, L.; Wu, J.; Huang, Y.; Lin, J. Synthesis, structure and characterization of a new trinuclear magnetic semiconductor $\mathrm{PbI}_{4}\left[\mathrm{Cu}\left(\mathrm{Me}_{2} \mathrm{dtc}\right)(\mathrm{bipy})\right]_{2}$. Solid State Sci. 2010, 12, 558-562. [CrossRef]

159. Liu, Q.; Yang, Y.; Huang, L.; Wu, D.; Kang, B.; Chen, C.; Deng, Y.; Lu, J. Study on an Assembly System Including Tetrathiovanadate. Syntheses and Structural Characterizations of $\mathrm{V}_{2} \mathrm{Cu}_{2} \mathrm{~S}_{4}$ Cubane-Like Clusters and $\mathrm{VS}_{4} \mathrm{Cu}_{4}$ Bimetallic Aggregates. Inorg. Chem. 1995, 34, 1884-1893. [CrossRef]

160. Yang, Y.; Liu, Q.; Huang, L.; Wu, D.; Kang, B.; Lu, J. Heterobimetallic aggregates of copper(I) with thiovanadate. Syntheses and characterizations of $\left(\mathrm{Et}_{4} \mathrm{~N}\right)_{3}\left[\mathrm{VS}_{4} \mathrm{Cu}_{4}\left(\mathrm{OC}_{4} \mathrm{H}_{8} \mathrm{dtc}\right)_{n}(\mathrm{PhS})_{4-\mathrm{n}}\right](\mathrm{n}=0,1,2)$. Inorg. Chem. 1993, 32, 5431-5432. [CrossRef]

161. Cao, R.; Bao, M.; Wu, D.; Su, W.; Hong, M. Syntheses and structures of cluster compounds containing WSe $\mathrm{Cu}_{\mathrm{n}}(\mathrm{n}=3,4) \mathrm{Cores}$ with dialkyldithiocarbamate ligands. J. Coord. Chem. 2000, 49, 227-238. [CrossRef]

162. Hong, M.; Zhang, Q.; Cao, R.; Wu, D.; Chen, J.; Zhang, W.; Liu, H.; Lu, J. Chemistry of the Tetraselenomolybdate Anion: Syntheses, Spectroscopic Results, and Structural Characterizations of Polynuclear Mo-Cu-Se Compounds Containing Thiolate Ligands. Inorg. Chem. 1997, 36, 6251-6260. [CrossRef]

163. Zhang, Q.-F.; Bao, M.-T.; Hong, M.-C.; Cao, R.; Song, Y.-L.; Xin, X.-Q. Syntheses, crystal structures and non-linear optical responses of two new heteroselenometallic cluster compounds containing dithiocarbamate ligands. J. Chem. Soc. Dalton Trans. 2000, 605-610. [CrossRef]

164. Zhiying, H.; Xinjian, L.; Beisheng, K.; Jiangnan, L.; Qiutian, L.; Maochun, H.; Hanqin, L. Heteronuclear W(Mo)/CuS complexes of dialkyldithiocarbamate. Syntheses of $\left(\mathrm{Et}_{4} \mathrm{~N}\right)_{2}\left[\mathrm{MCu}_{3} \mathrm{~S}_{4}\left(\mathrm{dtcR}_{2}\right)_{3}\right]$ and structures of $\left(\mathrm{Et}_{4} \mathrm{~N}\right)_{2}\left[\mathrm{MCu}_{3} \mathrm{~S}_{4}\left(\mathrm{dtcC}_{5} \mathrm{H}_{10}\right)_{3}\right] \cdot \mathrm{DMF}(\mathrm{M}=\mathrm{W}$ or Mo). Inorg. Chim. Acta 1990, 169, 25-29. [CrossRef] 
165. Zhu, H.; Huang, X.; Deng, Y.; Wu, D.; Chen, C.; Liu, Q. Synthesis and structural characterization of a linear copper(I) tetrathiomolybdate complex containing the Me2dtc- ligand, $\left(\mathrm{Et}_{4} \mathrm{~N}\right)_{2}\left[\mathrm{MoS}_{4}\left(\mathrm{CuMe}_{2} \mathrm{dtc}\right)_{2}\right]$. Inorg. Chim. Acta 1997, 256, 2934. [CrossRef]

166. Lei, X.; Huang, Z.; Liu, Q.; Hong, M.; Liu, H. A novel polynuclear molybdenum-copper cluster from tetrathiomolybdate: Preparation and structure of $\left(\mathrm{Et}_{4} \mathrm{~N}\right)_{2}\left[\mathrm{Mo}_{2} \mathrm{Cu}_{5} \mathrm{~S}_{8}\left(\mathrm{~S}_{2} \mathrm{CNMe}_{2}\right)_{3}\right] \cdot 2 \mathrm{H}_{2} \mathrm{O}$. Inorg. Chem. 1989, 28, 4302-4304. [CrossRef]

167. Scott, J.A.; Angeloski, A.; Aharonovich, I.; Lobo, C.J.; McDonagh, A.; Toth, M. In situ study of the precursor conversion reactions during solventless synthesis of $\mathrm{Co}_{9} \mathrm{~S}_{8}, \mathrm{Ni}_{3} \mathrm{~S}_{2}, \mathrm{Co}$ and Ni nanowires. Nanoscale 2018, 10, 15669-15676. [CrossRef]

168. Roffey, A.; Hollingsworth, N.; Islam, H.U.; Mercy, M.; Sankar, G.; Catlow, C.R.; Hogarth, G.; de Leeuw, N.H. Phase control during the synthesis of nickel sulfide nanoparticles from dithiocarbamate precursors. Nanoscale 2016, 8, 11067-11075. [CrossRef] [PubMed]

169. Breviglieri, S.T.; Cavalheiro, É.T.G.; Chierice, G.O. Correlation between ionic radius and thermal decomposition of Fe(II), Co(II), $\mathrm{Ni}(\mathrm{II}), \mathrm{Cu}(\mathrm{II})$ and $\mathrm{Zn}(\mathrm{II})$ diethanoldithiocarbamates. Thermochim. Acta 2000, 356, 79-84. [CrossRef]

170. Roy, P.; Srivastava, S.K. Nanostructured copper sulfides: Synthesis, properties and applications. CrystEngComm 2015, 17, 7801-7815. [CrossRef]

171. Kim, Y.-Y.; Walsh, D. Metal sulfidenanoparticles synthesized via enzyme treatment of biopolymer stabilized nanosuspensions. Nanoscale 2010, 2, 240-247. [CrossRef]

172. McCain, M.N.; Metz, A.W.; Yang, Y.; Stern, C.L.; Marks, T.J. Bis[di(2,2,2-trifluoroethyl) dithiocarbamato] CuII: A Volatile Precursor for the Efficient Growth of Cuprous Sulfide Films by MOCVD. Chem. Vap. Depos. 2005, 11, 291-294. [CrossRef]

173. Chen, Y.-B.; Chen, L.; Wu, L.-M. Water-induced thermolytic formation of homogeneous core - shell CuS microspheres and their shape retention on desulfurization. Cryst. Growth Des. 2008, 8, 2736-2740. [CrossRef]

174. Jen-La Plante, I.; Zeid, T.W.; Yang, P.; Mokari, T. Synthesis of metal sulfide nanomaterials via thermal decomposition of singlesource precursors. J. Mater. Chem. 2010, 20, 6612-6617. [CrossRef]

175. Lou, Y.; Samia, A.C.; Cowen, J.; Banger, K.; Chen, X.; Lee, H.; Burda, C. Evaluation of the photoinduced electron relaxation dynamics of $\mathrm{Cu} 1.8 \mathrm{~S}$ quantum dots. Phys. Chem. Chem. Phys. 2003, 5, 1091-1095. [CrossRef]

176. Liu, Z.; Xu, D.; Liang, J.; Shen, J.; Zhang, S.; Qian, Y. Growth of Cu2S ultrathin nanowires in a binary surfactant solvent. J. Phys. Chem. B 2005, 109, 10699-10704. [CrossRef]

177. Wu, Y.; Wadia, C.; Ma, W.; Sadtler, B.; Alivisatos, A.P. Synthesis and photovoltaic application of copper (I) sulfide nanocrystals. Nano Lett. 2008, 8, 2551-2555. [CrossRef]

178. Luther, J.M.; Jain, P.K.; Ewers, T.; Alivisatos, A.P. Localized surface plasmon resonances arising from free carriers in doped quantum dots. Nat. Mater. 2011, 10, 361-366. [CrossRef]

179. Tian, Q.; Jiang, F.; Zou, R.; Liu, Q.; Chen, Z.; Zhu, M.; Yang, S.; Wang, J.; Wang, J.; Hu, J. Hydrophilic Cu9S5 nanocrystals: A photothermal agent with a $25.7 \%$ heat conversion efficiency for photothermal ablation of cancer cells in vivo. ACS Nano 2011, 5, 9761-9771. [CrossRef]

180. Li, B.; Wang, Q.; Zou, R.; Liu, X.; Xu, K.; Li, W.; Hu, J. Cu $\mathrm{Cu}_{7.2} \mathrm{~S}_{4}$ nanocrystals: A novel photothermal agent with a $56.7 \%$ photothermal conversion efficiency for photothermal therapy of cancer cells. Nanoscale 2014, 6, 3274-3282. [CrossRef]

181. Botha, N.L.; Ajibade, P.A. Optical and structural characterization of copper sulphide nanoparticles from copper(II) piperidine dithiocarbamate. Opt. Quantum Electron. 2020, 52, 337. [CrossRef]

182. ul Ain, N.; Zia ur, R.; Aamir, A.; Khan, Y.; Rehman, M.-u.; Lin, D.-J. Catalytic and photocatalytic efficacy of hexagonal CuS nanoplates derived from copper(II) dithiocarbamate. Mater. Chem. Phys. 2020, 242, 122408. [CrossRef]

183. Solomane, N.; Ajibade, P.A. Synthesis and crystal structure of bis(thiomorpholinyldithiocarbamato)Cu(II) complex and its use as precursor for CuS nanoparticles photocatalyst for the degradation of organic dyes. J. Sulfur Chem. 2020, 42, 167-179. [CrossRef]

184. Motaung, M.P.; Osuntokun, J.; Onwudiwe, D.C. The heat-up synthesis of monodispersed Bi2S3 and Cu7S4 nanoparticles from novel precursor complexes and their characterizations. Mater. Sci. Semicond. Process. 2019, 99, 92-98. [CrossRef]

185. Cui, J.; Xu, S.; Guo, C.; Jiang, R.; James, T.D.; Wang, L. Highly efficient photothermal semiconductor nanocomposites for photothermal imaging of latent fingerprints. Anal. Chem. 2015, 87, 11592-11598. [CrossRef]

186. Estrada, A.C.; Silva, F.M.; Soares, S.F.; Coutinho, J.A.; Trindade, T. An ionic liquid route to prepare copper sulphide nanocrystals aiming at photocatalytic applications. RSC Adv. 2016, 6, 34521-34528. [CrossRef]

187. Olalekan, O.C.; Onwudiwe, D.C. Temperature controlled evolution of pure phase $\mathrm{Cu}_{9} \mathrm{~S}_{5}$ nanoparticles by solvothermal process. Front. Mater. 2021, 8, 211.

188. Khalid, S.; Ahmed, E.; Azad Malik, M.; Lewis, D.J.; Abu Bakar, S.; Khan, Y.; O’Brien, P. Synthesis of pyrite thin films and transition metal doped pyrite thin films by aerosol-assisted chemical vapour deposition. New J. Chem. 2015, 39, 1013-1021. [CrossRef]

189. Majid, S.; Ahmad, K.S. Optical and morphological properties of environmentally benign Cu-Tin sulphide thin films grown by physical vapor deposition technique. Mater. Res. Express 2018, 6, 036406. [CrossRef]

190. Hollingsworth, N.; Roffey, A.; Islam, H.-U.; Mercy, M.; Roldan, A.; Bras, W.; Wolthers, M.; Catlow, C.R.A.; Sankar, G.; Hogarth, G.; et al. Active Nature of Primary Amines during Thermal Decomposition of Nickel Dithiocarbamates to Nickel Sulfide Nanoparticles. Chem. Mater. 2014, 26, 6281-6292. [CrossRef]

191. Sarker, J.C.; Hogarth, G. Dithiocarbamate Complexes as Single Source Precursors to Nanoscale Binary, Ternary and Quaternary Metal Sulfides. Chem. Rev. 2021, 121, 6057-6123. [CrossRef] 
192. Roffey, A.; Hollingsworth, N.; Islam, H.-U.; Bras, W.; Sankar, G.; De Leeuw, N.H.; Hogarth, G. Fe(II) and Fe(III) dithiocarbamate complexes as single source precursors to nanoscale iron sulfides: A combined synthetic and in situ XAS approach. Nanoscale Adv. 2019, 1, 2965-2978. [CrossRef]

193. Cui, Y.; Ren, J.; Chen, G.; Qian, Y.; Xie, Y. A simple route to synthesize $\mathrm{MInS}_{2}(\mathrm{M}=\mathrm{Cu}, \mathrm{Ag})$ nanorods from single-molecule precursors. Chem. Lett. 2001, 30, 236-237. [CrossRef]

194. Park, J.-H.; Afzaal, M.; Kemmler, M.; O’Brien, P.; Otway, D.J.; Raftery, J.; Waters, J. The deposition of thin films of CuME 2 by CVD techniques (M= In, Ga and E= S, Se). J. Mater. Chem. 2003, 13, 1942-1949. [CrossRef]

195. Pan, D.; An, L.; Sun, Z.; Hou, W.; Yang, Y.; Yang, Z.; Lu, Y. Synthesis of Cu- In- S ternary nanocrystals with tunable structure and composition. J. Am. Chem. Soc. 2008, 130, 5620-5621. [CrossRef]

196. Hao, Z.; Cui, Y.; Wang, G. Colloidal synthesis of wurtzite CuInS 2 nanocrystals and their photovoltaic application. Mater. Lett. 2015, 146, 77-80. [CrossRef]

197. Shin, S.J.; Koo, J.-J.; Lee, J.-K.; Chung, T.D. Unique Luminescence of Hexagonal Dominant Colloidal Copper Indium Sulphide Quantum Dots in Dispersed Solutions. Sci. Rep. 2019, 9, 1-8. [CrossRef]

198. Motaung, M.P.; Onwudiwe, D.C.; Wei, L.; Lou, C. CuS, $\mathrm{In}_{2} \mathrm{~S}_{3}$ and CuInS 2 nanoparticles by microwave-assisted solvothermal route and their electrochemical studies. J. Phys. Chem. Solids 2021, 160, 110319. [CrossRef]

199. Li, Q.; Zhai, L.; Zou, C.; Huang, X.; Zhang, L.; Yang, Y.; Huang, S. Wurtzite CuInS 2 and $\mathrm{CuIn}_{\mathrm{x}} \mathrm{Ga}_{1-\mathrm{x}} \mathrm{S}_{2}$ nanoribbons: Synthesis, optical and photoelectrical properties. Nanoscale 2013, 5, 1638-1648. [CrossRef]

200. Li, Q.; Zou, C.; Zhai, L.; Zhang, L.; Yang, Y.; Huang, S. Synthesis of wurtzite CuInS 2 nanowires by $\mathrm{Ag}_{2}$ S-catalyzed growth. CrystEngComm 2013, 15, 1806-1813. [CrossRef]

201. Nomura, R.; Kanaya, K.; Matsuda, H. Preparation of Copper-Indium-Sulfide thin films by solution Pyrolysis of organometallic sources. Chem. Lett. 1988, 17, 1849-1850. [CrossRef]

202. Nomura, R.; Fujii, S.; Kanaya, K.; Matsuda, H. Oxygen-or sulphur-containing organoindium compounds for precursors of indium oxide and sulphide thin films. Polyhedron 1990, 9, 361-366. [CrossRef]

203. Nowotny, M.; Foro, S.; Heinschke, S.; Hoffmann, R.C.; Schneider, J.J. 1,2-Dithiooxalato-Bridged Heterobimetallic Complexes as Single-Source Precursors for Ternary Metal Sulfide Semiconductors. Eur. J. Inorg. Chem. 2015, 2015, 512-519. [CrossRef]

204. Pan, D.; Weng, D.; Wang, X.; Xiao, Q.; Chen, W.; Xu, C.; Yang, Z.; Lu, Y. Alloyed semiconductor nanocrystals with broad tunable band gaps. Chem. Commun. 2009, 4221-4223. [CrossRef] [PubMed]

205. Hehemann, D.G.; Lau, J.E.; Harris, J.D.; Hoops, M.D.; Duffy, N.V.; Fanwick, P.E.; Khan, O.; Jin, M.H.-C.; Hepp, A.F. Synthesis, characterization and decomposition studies of tris (N, N-dibenzyldithiocarbamato) indium (III): Chemical spray deposition of polycrystalline CuInS 2 on copper films. Mater. Sci. Eng. B 2005, 116, 381-389. [CrossRef]

206. Wang, X.; Pan, D.; Weng, D.; Low, C.-Y.; Rice, L.; Han, J.; Lu, Y. A general synthesis of Cu-In-S based multicomponent solid-Solution nanocrystals with tunable band gap, size, and structure. J. Phys. Chem. C 2010, 114, 17293-17297. [CrossRef]

207. Zou, C.; Zhang, L.; Zhai, L.; Lin, D.; Gao, J.; Li, Q.; Yang, Y.; Chen, X.a.; Huang, S. Solution-based synthesis of quaternary $\mathrm{Cu}-\mathrm{In}-\mathrm{Zn}-\mathrm{S}$ nanobelts with tunable composition and band gap. Chem. Commun. 2011, 47, 5256-5258. [CrossRef]

208. Lin, Y.; Zhang, F.; Pan, D. A facile route to $(\mathrm{ZnS})_{\mathrm{x}}\left(\mathrm{CuInS}_{2}\right)_{1-\mathrm{x}}$ hierarchical microspheres with excellent water-splitting ability. J. Mater. Chem. 2012, 22, 22619-22623. [CrossRef]

209. Xu, D.; Shen, S.; Zhang, Y.; Gu, H.; Wang, Q. Selective synthesis of ternary copper-antimony sulfide nanocrystals. Inorg. Chem. 2013, 52, 12958-12962. [CrossRef]

210. Deng, M.; Shen, S.; Zhang, Y.; Xu, H.; Wang, Q. A generalized strategy for controlled synthesis of ternary metal sulfide nanocrystals. New J. Chem. 2014, 38, 77-83. [CrossRef]

211. Adekoya, J.A.; Khan, M.D.; Revaprasadu, N. Phase transition in $\mathrm{Cu}_{2+\mathrm{x}} \mathrm{SnS}_{3+\mathrm{y}}(0 \leq \mathrm{x} \leq 2 ; 0 \leq \mathrm{y} \leq 1)$ ternary systems synthesized from complexes of coumarin derived thiocarbamate motifs: Optical and morphological properties. RSC Adv. 2019, 9, 35706-35716. [CrossRef]

212. van Embden, J.; Mendes, J.O.; Jasieniak, J.J.; Chesman, A.S.R.; Della Gaspera, E. Solution-Processed CuSbS 2 Thin Films and Superstrate Solar Cells with CdS/ $\mathrm{In}_{2} \mathrm{~S}_{3}$ Buffer Layers. ACS Appl. Energy Mater. 2020, 3, 7885-7895. [CrossRef]

213. Matthews, P.D.; McNaughter, P.D.; Lewis, D.J.; O'Brien, P. Shining a light on transition metal chalcogenides for sustainable photovoltaics. Chem. Sci. 2017, 8, 4177-4187. [CrossRef] [PubMed]

214. Olatunde, O.C.; Onwudiwe, D.C. Chapter 3-Copper-based ternary metal sulfide nanocrystals embedded in graphene oxide as photocatalyst in water treatment. In Nanotechnology in the Beverage Industry; Amrane, A., Rajendran, S., Nguyen, T.A., Assadi, A.A., Sharoba, A.M., Eds.; Elsevier: Amsterdam, The Netherlands, 2020; pp. 51-113.

215. Tshabalala, T.W.; Onwudiwe, D.C.; Elemike, E.E.; Okpara, E.C. Structural and optical characterizations of $\mathrm{Cu}_{2} \mathrm{SnS}_{3} \mathrm{nanoparticles}$ and the electrochemical studies. Results Chem. 2021, submitted.

216. Wang, Y.-H.A.; Bao, N.; Gupta, A. Shape-controlled synthesis of semiconducting $\mathrm{CuFeS}_{2}$ nanocrystals. Solid State Sci. 2010, 12, 387-390. [CrossRef]

217. Roffey, A.; Hollingsworth, N.; Hogarth, G. Synthesis of ternary sulfide nanomaterials using dithiocarbamate complexes as single source precursors. Nanoscale Adv. 2019, 1, 3056-3066. [CrossRef]

218. Ramasamy, K.; Malik, M.A.; O’Brien, P. The chemical vapor deposition of $\mathrm{Cu}_{2} \mathrm{ZnSnS}_{4}$ thin films. Chem. Sci. 2011, 2, 1170-1172. [CrossRef] 
219. Chernomordik, B.D.; Béland, A.E.; Deng, D.D.; Francis, L.F.; Aydil, E.S. Microstructure evolution and crystal growth in $\mathrm{Cu}_{2} \mathrm{ZnSnS}_{4}$ thin films formed by annealing colloidal nanocrystal coatings. Chem. Mater. 2014, 26, 3191-3201. [CrossRef]

220. Exarhos, S.; Bozhilov, K.; Mangolini, L. Spray pyrolysis of CZTS nanoplatelets. Chem. Commun. 2014, 50, 11366-11369. [CrossRef] [PubMed]

221. Zhang, W.; Zhai, L.; He, N.; Zou, C.; Geng, X.; Cheng, L.; Dong, Y.; Huang, S. Solution-based synthesis of wurtzite Cu ${ }_{2}$ ZnSnS $_{4}$ nanoleaves introduced by $\alpha-\mathrm{Cu}_{2} \mathrm{~S}$ nanocrystals as a catalyst. Nanoscale 2013, 5, 8114-8121. [CrossRef] [PubMed]

222. Liu, K.; Yao, B.; Li, Y.; Ding, Z.; Sun, H.; Jiang, Y.; Wang, G.; Pan, D. A versatile strategy for fabricating various $\mathrm{Cu}_{2} \mathrm{ZnSnS}_{4}$ precursor solutions. J. Mater. Chem. C 2017, 5, 3035-3041. [CrossRef]

223. Wang, G.; Zhao, W.; Cui, Y.; Tian, Q.; Gao, S.; Huang, L.; Pan, D. Fabrication of a $\mathrm{Cu}_{2} \mathrm{ZnSn}(\mathrm{S}, \mathrm{Se})_{4}$ photovoltaic device by a low-toxicity ethanol solution process. ACS Appl. Mater. Interfaces 2013, 5, 10042-10047. [CrossRef]

224. Metzler-Nolte, N.; Kraatz, H. Concepts and Models in Bioinorganic Chemistry; Wiley-VCH: Weinheim, Germany, 2006.

225. Horn, N.; Møller, L.B.; Nurchi, V.M.; Aaseth, J. Chelating principles in Menkes and Wilson diseases: Choosing the right compounds in the right combinations at the right time. J. Inorg. Biochem. 2019, 190, 98-112. [CrossRef] [PubMed]

226. Kodama, H.; Sato, E.; Gu, Y.H.; Shiga, K.; Fujisawa, C.; Kozuma, T. Effect of copper and diethyldithiocarbamate combination therapy on the macular mouse, an animal model of Menkes disease. J. Inherit. Metab. Dis. Off. J. Soc. Study Inborn Errors Metab. 2005, 28, 971-978. [CrossRef]

227. Nobel, C.S.I.; Kimland, M.; Lind, B.; Orrenius, S.; Slater, A.F.G. Dithiocarbamates Induce Apoptosis in Thymocytes by Raising the Intracellular Level of Redox-active Copper. J. Biol. Chem. 1995, 270, 26202-26208. [CrossRef]

228. Buac, D.; Schmitt, S.; Ventro, G.; Rani Kona, F.; Ping Dou, Q. Dithiocarbamate-based coordination compounds as potent proteasome inhibitors in human cancer cells. Mini Rev. Med. Chem. 2012, 12, 1193-1201. [CrossRef]

229. Neims, A.H.; Coffey, D.S.; Hellerman, L. Interaction between tetraethylthiuram disulfide and the sulfhydryl groups of D-amino acid oxidase and of hemoglobin. J. Biol. Chem. 1966, 241, 5941-5948. [CrossRef]

230. Hosni, M.; Meskini, N.; Prigent, A.F.; Anker, G.; Joulain, C.; El Habib, R.; Lagarde, M. Diethyldithiocarbamate (ditiocarb sodium) effect on arachidonic acid metabolism in human mononuclear cells. Glutathione peroxidase-like activity. Biochem. Pharmacol. 1992, 43, 1319-1329. [CrossRef]

231. Zemaitis, M.A.; Greene, F.E. In vivo and in vitro effects of thiuram disulfides and dithiocarbamates on hepatic microsomal drug metabolism in the rat. Toxicol. Appl. Pharmacol. 1979, 48, 343-350. [CrossRef]

232. Dierickx, P.J. In vitro interaction of dithiocarb with rat liver glutathione s-transferases. Pharmacol. Res. Commun. 1984, 16, 135-143. [CrossRef]

233. Eneanya, D.I.; Bianchine, J.R.; Duran, D.O.; Andresen, B.D. The actions and metabolic fate of disulfiram. Annu. Rev. Pharmacol. Toxicol. 1981, 21, 575-596. [CrossRef] [PubMed]

234. Suh, J.J.; Pettinati, H.M.; Kampman, K.M.; O’Brien, C.P. The status of disulfiram: A half of a century later. J. Clin. Psychopharmacol. 2006, 26, 290-302. [CrossRef]

235. Heilig, M.; Egli, M. Pharmacological treatment of alcohol dependence: Target symptoms and target mechanisms. Pharmacol. Ther. 2006, 111, 855-876. [CrossRef]

236. Cen, D.; Brayton, D.; Shahandeh, B.; Meyskens, F.L.; Farmer, P.J. Disulfiram facilitates intracellular Cu uptake and induces apoptosis in human melanoma cells. J. Med. Chem. 2004, 47, 6914-6920. [CrossRef]

237. Lewis, D.J.; Deshmukh, P.; Tedstone, A.A.; Tuna, F.; O’Brien, P. On the interaction of copper (II) with disulfiram. Chem. Commun. 2014, 50, 13334-13337. [CrossRef] [PubMed]

238. Santini, C.; Pellei, M.; Gandin, V.; Porchia, M.; Tisato, F.; Marzano, C. Advances in Copper Complexes as Anticancer Agents. Chem. Rev. 2014, 114, 815-862. [CrossRef] [PubMed]

239. Imran, M.; Liviu, M.; Latif, S.; Mahmood, Z.; Naimat, I.; Zaman, S.S.; Fatima, S. Antibacterial Co(II), Ni(II), Cu(II) and Zn(II) complexes with biacetyl-derived Schiff bases. J. Serb. Chem. Soc. 2010, 75, 1075-1084. [CrossRef]

240. Anacona, J.; Rangel, V.; Lorono, M.; Camus, J. Tetradentate metal complexes derived from cephalexin and 2, 6-diacetylpyridine bis (hydrazone): Synthesis, characterization and antibacterial activity. Spectrochim. Acta Part A Mol. Biomol. Spectrosc. 2015, 149, 23-29. [CrossRef]

241. Johnstone, T.C.; Suntharalingam, K.; Lippard, S.J. The next generation of platinum drugs: Targeted Pt (II) agents, nanoparticle delivery, and Pt (IV) prodrugs. Chem. Rev. 2016, 116, 3436-3486. [CrossRef] [PubMed]

242. Wehbe, M.; Leung, A.W.Y.; Abrams, M.J.; Orvig, C.; Bally, M.B. A Perspective—can copper complexes be developed as a novel class of therapeutics? Dalton Trans. 2017, 46, 10758-10773. [CrossRef]

243. Wang, T.; Fu, Y.; Huang, T.; Liu, Y.; Wu, M.; Yuan, Y.; Li, S.; Li, C. Copper Ion Attenuated the Antiproliferative Activity of Di-2-pyridylhydrazone Dithiocarbamate Derivative; However, There Was a Lack of Correlation between ROS Generation and Antiproliferative Activity. Molecules 2016, 21, 1088. [CrossRef] [PubMed]

244. Ronconi, L.; Marzano, C.; Zanello, P.; Corsini, M.; Miolo, G.; Macca, C.; Trevisan, A.; Fregona, D. Gold (III) dithiocarbamate derivatives for the treatment of cancer: Solution chemistry, DNA binding, and hemolytic properties. J. Med. Chem. 2006, 49, 1648-1657. [CrossRef]

245. Milacic, V.; Chen, D.; Ronconi, L.; Landis-Piwowar, K.R.; Fregona, D.; Dou, Q.P. A novel anticancer gold (III) dithiocarbamate compound inhibits the activity of a purified $20 \mathrm{~S}$ proteasome and $26 \mathrm{~S}$ proteasome in human breast cancer cell cultures and xenografts. Cancer Res. 2006, 66, 10478-10486. [CrossRef] 
246. Schreck, R.; Meier, B.; Männel, D.N.; Dröge, W.; Baeuerle, P.A. Dithiocarbamates as potent inhibitors of nuclear factor kappa B activation in intact cells. J. Exp. Med. 1992, 175, 1181-1194. [CrossRef]

247. Nobel, C.S.I.; Burgess, D.H.; Zhivotovsky, B.; Burkitt, M.J.; Orrenius, S.; Slater, A.F. Mechanism of dithiocarbamate inhibition of apoptosis: Thiol oxidation by dithiocarbamate disulfides directly inhibits processing of the caspase-3 proenzyme. Chem. Res. Toxicol. 1997, 10, 636-643. [CrossRef] [PubMed]

248. Tawari, P.E.; Wang, Z.; Najlah, M.; Tsang, C.W.; Kannappan, V.; Liu, P.; McConville, C.; He, B.; Armesilla, A.L.; Wang, W. The cytotoxic mechanisms of disulfiram and copper(II) in cancer cells. Toxicol. Res. 2015, 4, 1439-1442. [CrossRef]

249. Chen, D.; Cui, Q.C.; Yang, H.; Dou, Q.P. Disulfiram, a clinically used anti-alcoholism drug and copper-binding agent, induces apoptotic cell death in breast cancer cultures and xenografts via inhibition of the proteasome activity. Cancer Res. 2006, 66, 10425-10433. [CrossRef]

250. Lu, X.; Lin, B.; Xu, N.; Huang, H.; Wang, Y.; Lin, J.-M. Evaluation of the accumulation of disulfiram and its copper complex in A549 cells using mass spectrometry. Talanta 2020, 211, 120732. [CrossRef]

251. Wang, F.; Jiao, P.; Qi, M.; Frezza, M.; Dou, Q.; Yan, B. Turning tumor-promoting copper into an anti-cancer weapon via high-throughput chemistry. Curr. Med. Chem. 2010, 17, 2685-2698. [CrossRef]

252. Viola-Rhenals, M.; Rieber, M.S.; Rieber, M. Suppression of survival in human SKBR3 breast carcinoma in response to metalchelator complexes is preferential for copper-dithiocarbamate. Biochem. Pharmacol. 2006, 71, 722-734. [CrossRef] [PubMed]

253. Matias, A.C.; Manieri, T.M.; Cipriano, S.S.; Carioni, V.M.; Nomura, C.S.; Machado, C.M.; Cerchiaro, G. Diethyldithiocarbamate induces apoptosis in neuroblastoma cells by raising the intracellular copper level, triggering cytochrome c release and caspase activation. Toxicol. Vitr. 2013, 27, 349-357. [CrossRef] [PubMed]

254. Fujie, T.; Segawa, Y.; Yoshida, E.; Kimura, T.; Fujiwara, Y.; Yamamoto, C.; Satoh, M.; Naka, H.; Kaji, T. Induction of metallothionein isoforms by copper diethyldithiocarbamate in cultured vascular endothelial cells. J. Toxicol. Sci. 2016, 41, 225-232. [CrossRef] [PubMed]

255. Viola-Rhenals, M.; Rieber, M.S.; Rieber, M. Role of peroxidases, thiols and Bak/Bax in tumor cell susceptibility to Cu[DEDTC] 2. Biochem. Pharmacol. 2007, 74, 841-850. [CrossRef]

256. Wehbe, M.; Lo, C.; Leung, A.W.; Dragowska, W.H.; Ryan, G.M.; Bally, M.B. Copper(II) complexes of bidentate ligands exhibit potent anti-cancer activity regardless of platinum sensitivity status. Investig. New Drugs 2017, 35, 682-690. [CrossRef]

257. Daniel, K.G.; Chen, D.; Orlu, S.; Cui, Q.C.; Miller, F.R.; Dou, Q.P. Clioquinol and pyrrolidine dithiocarbamate complex with copper to form proteasome inhibitors and apoptosis inducers in human breast cancer cells. Breast Cancer Res. 2005, 7, 1-12. [CrossRef]

258. Chen, D.; Peng, F.; Cui, Q.C.; Daniel, K.G.; Orlu, S.; Liu, J.; Dou, Q.P. Inhibition of prostate cancer cellular proteasome activity by a pyrrolidine dithiocarbamate-copper complex is associated with suppression of proliferation and induction of apoptosis. Front. Biosci. 2005, 10, 2932-2939. [CrossRef]

259. Brustolin, L.; Pettenuzzo, N.; Nardon, C.; Quarta, S.; Montagner, I.; Pontisso, P.; Rosato, A.; Conte, P.; Merigliano, S.; Fregona, $\mathrm{D}$. Labelled micelles for the delivery of cytotoxic $\mathrm{Cu}(\mathrm{II})$ and $\mathrm{Ru}(\mathrm{III})$ compounds in the treatment of aggressive orphan cancers: Design and biological in vitro data. Inorg. Biochem. 2020, 213, 111259. [CrossRef]

260. Ajibade, P.A.; Andrew, F.P.; Botha, N.L.; Solomane, N. Synthesis, Crystal Structures and Anticancer Studies of Morpholinyldithiocarbamato $\mathrm{Cu}(\mathrm{II})$ and $\mathrm{Zn}(\mathrm{II})$ Complexes. Molecules 2020, 25, 3584. [CrossRef]

261. Ajibade, P.A.; Fatokun, A.A.; Andrew, F.P. Synthesis, characterization and anti-cancer studies of $\mathrm{Mn}(\mathrm{II}), \mathrm{Cu}(\mathrm{II}), \mathrm{Zn}(\mathrm{II}) \mathrm{and} \mathrm{Pt}(\mathrm{II})$ dithiocarbamate complexes-Crystal structures of the $\mathrm{Cu}(\mathrm{II})$ and $\mathrm{Pt}(\mathrm{II})$ complexes. Inorg. Chim. Acta 2020, 504, 119431. [CrossRef]

262. Sedlacek, J.; Martins, L.M.D.R.S.; Danek, P.; Pombeiro, A.J.L.; Cvek, B. Diethyldithiocarbamate complexes with metals used as food supplements show different effects in cancer cells. J. Appl. Biomed. 2014, 12, 301-308. [CrossRef]

263. Daniel, K.G.; Chen, D.; Yan, B.; Dou, Q.P. Copper-binding compounds as proteasome inhibitors and apoptosis inducers in human cancer. Front. Biosci. 2007, 12, 135-144. [CrossRef] [PubMed]

264. Zhang, H.; Wu, J.-S.; Peng, F. Potent anticancer activity of pyrrolidine dithiocarbamate-copper complex against cisplatin-resistant neuroblastoma cells. Anti-Cancer Drugs 2008, 19, 125-132. [CrossRef] [PubMed]

265. Wang, F.; Zhai, S.; Liu, X.; Li, L.; Wu, S.; Dou, Q.P.; Yan, B. A novel dithiocarbamate analogue with potentially decreased ALDH inhibition has copper-dependent proteasome-inhibitory and apoptosis-inducing activity in human breast cancer cells. Cancer Lett. 2011, 300, 87-95. [CrossRef] [PubMed]

266. Yu, Z.; Wang, F.; Milacic, V.; Li, X.; Cui, Q.C.; Zhang, B.; Yan, B.; Dou, Q.P. Evaluation of copper-dependent proteasome-inhibitory and apoptosis-inducing activities of novel pyrrolidine dithiocarbamate analogues. Int. J. Mol. Med. 2007, 20, 919-925. [CrossRef] [PubMed]

267. Turnaturi, R.; Oliveri, V.; Viale, M.; Monticone, M.; Vecchio, G. Antiproliferative and antioxidant activity of glycoconjugates of dithiocarbamates and their copper(II) and zinc(II) complexes. ChemPlusChem 2015, 80, 1786. [CrossRef] [PubMed]

268. Wu, W.; Yu, L.; Jiang, Q.; Huo, M.; Lin, H.; Wang, L.; Chen, Y.; Shi, J. Enhanced tumor-specific disulfiram chemotherapy by in situ $\mathrm{Cu} 2+$ chelation-initiated nontoxicity-to-toxicity transition. J. Am. Chem. Soc. 2019, 141, 11531-11539. [CrossRef]

269. Zhou, L.; Yang, L.; Yang, C.; Liu, Y.; Chen, Q.; Pan, W.; Cai, Q.; Luo, L.; Liu, L.; Jiang, S. Membrane loaded copper oleate PEGylated liposome combined with disulfiram for improving synergistic antitumor effect in vivo. Pharm. Res. 2018, 35, 1-11. [CrossRef] [PubMed] 
270. Peng, X.; Pan, Q.; Zhang, B.; Wan, S.; Li, S.; Luo, K.; Pu, Y.; He, B. Highly stable, coordinated polymeric nanoparticles loading copper(II) diethyldithiocarbamate for combinational chemo/chemodynamic therapy of cancer. Biomacromolecules 2019, 20, 2372-2383. [CrossRef]

271. Bakthavatsalam, S.; Wiangnak, P.; George, D.J.; Zhang, T.; Franz, K.J. Dithiocarbamate prodrugs activated by prostate specific antigen to target prostate cancer. Bioorganic Med. Chem. Lett. 2020, 30, 127148. [CrossRef]

272. Bakthavatsalam, S.; Sleeper, M.L.; Dharani, A.; George, D.J.; Zhang, T.; Franz, K.J. Leveraging $\gamma$-Glutamyl Transferase To Direct Cytotoxicity of Copper Dithiocarbamates against Prostate Cancer Cells. Angew. Chem. Int. Ed. 2018, 57, 12780-12784. [CrossRef]

273. Wehbe, M.; Anantha, M.; Shi, M.; Leung, A.W.-Y.; Dragowska, W.H.; Sanche, L.; Bally, M.B. Development and optimization of an injectable formulation of copper diethyldithiocarbamate, an active anticancer agent. Int. J. Nanomed. 2017, 12, 4129. [CrossRef]

274. Peng, Y.; Liu, P.; Meng, Y.; Hu, S.; Ding, J.; Zhou, W. Nanoscale Copper (II)-Diethyldithiocarbamate Coordination Polymer as a Drug Self-Delivery System for Highly Robust and Specific Cancer Therapy. Mol. Pharm. 2020, 17, 2864-2873. [CrossRef]

275. Marengo, A.; Forciniti, S.; Dando, I.; Dalla Pozza, E.; Stella, B.; Tsapis, N.; Yagoubi, N.; Fanelli, G.; Fattal, E.; Heeschen, C. Pancreatic cancer stem cell proliferation is strongly inhibited by diethyldithiocarbamate-copper complex loaded into hyaluronic acid decorated liposomes. Biochim. Et Biophys. Acta (BBA) Gen. Subj. 2019, 1863, 61-72. [CrossRef]

276. Li, X.; Du, K.; Sun, J.; Feng, F. Apoferritin as a Carrier of $\mathrm{Cu}(\mathrm{II})$ Diethyldithiocarbamate and Biomedical Application for Glutathione-Responsive Combination Chemotherapy. ACS Appl. Bio Mater. 2019, 3, 654-663. [CrossRef]

277. Chen, W.; Yang, W.; Chen, P.; Huang, Y.; Li, F. Disulfiram copper nanoparticles prepared with a stabilized metal ion ligand complex method for treating drug-resistant prostate cancers. ACS Appl. Mater. Interfaces 2018, 10, 41118-41128. [CrossRef]

278. Ren, L.; Feng, W.; Shao, J.; Ma, J.; Xu, M.; Zhu, B.-Z.; Zheng, N.; Liu, S. Diethyldithiocarbamate-copper nanocomplex reinforces disulfiram chemotherapeutic efficacy through light-triggered nuclear targeting. Theranostics 2020, 10, 6384. [CrossRef]

279. Shi, H.; Suo, Y.; Zhang, Z.; Liu, R.; Liu, H.; Cheng, Z. Copper (II)-disulfiram loaded melanin-dots for cancer theranostics. Nanomed. Nanotechnol. Biol. Med. 2021, 32, 102340. [CrossRef]

280. Cvek, B.; Milacic, V.; Taraba, J.; Dou, Q.P. Ni(II), Cu(II), and Zn(II) diethyldithiocarbamate complexes show various activities against the proteasome in breast cancer cells. J. Med. Chem. 2008, 51, 6256-6258. [CrossRef] [PubMed]

281. Cvek, B.; Dvorak, Z. Targeting of nuclear factor-кB and proteasome by dithiocarbamate complexes with metals. Curr. Pharm. Des. 2007, 13, 3155-3167. [CrossRef] [PubMed]

282. Milacic, V.; Chen, D.; Giovagnini, L.; Diez, A.; Fregona, D.; Dou, Q.P. Pyrrolidine dithiocarbamate-zinc (II) and-copper (II) complexes induce apoptosis in tumor cells by inhibiting the proteasomal activity. Toxicol. Appl. Pharmacol. 2008, $231,24-33$. [CrossRef] [PubMed]

283. Fujie, T.; Murakami, M.; Yoshida, E.; Tachinami, T.; Shinkai, Y.; Fujiwara, Y.; Yamamoto, C.; Kumagai, Y.; Naka, H.; Kaji, T. Copper diethyldithiocarbamate as an activator of Nrf2 in cultured vascular endothelial cells. J. Biol. Inorg. Chem. 2016, 21, 263-273. [CrossRef] [PubMed]

284. Yeo, C.I.; Tiekink, E.R.T.; Chew, J. Insights into the Antimicrobial Potential of Dithiocarbamate Anions and Metal-Based Species. Inorganics 2021, 9, 48. [CrossRef]

285. Chen, C.; Yang, K.-W.; Wu, L.-Y.; Li, J.-Q.; Sun, L.-Y. Disulfiram as a potent metallo- $\beta$-lactamase inhibitor with dual functional mechanisms. Chem. Commun. 2020, 56, 2755-2758. [CrossRef]

286. Wang, M.-M.; Chu, W.-C.; Yang, Y.; Yang, Q.-Q.; Qin, S.-S.; Zhang, E. Dithiocarbamates: Efficient metallo- $\beta$-lactamase inhibitors with good antibacterial activity when combined with meropenem. Bioorganic Med. Chem. Lett. 2018, 28, 3436-3440. [CrossRef]

287. Balakrishnan, S.; Duraisamy, S.; Kasi, M.; Kandasamy, S.; Sarkar, R.; Kumarasamy, A. Syntheses, physicochemical characterization, antibacterial studies on potassium morpholine dithiocarbamate nickel (II), copper (II) metal complexes and their ligands. Heliyon 2019, 5, e01687. [CrossRef] [PubMed]

288. Oladipo, S.D.; Omondi, B.; Mocktar, C. Synthesis and structural studies of nickel(II)- and copper(II)-N,N'-diarylformamidine dithiocarbamate complexes as antimicrobial and antioxidant agents. Polyhedron 2019, 170, 712-722. [CrossRef]

289. Oladipo, S.D.; Mocktar, C.; Omondi, B. In vitro biological studies of heteroleptic Ag(I) and Cu(I) unsymmetrical N,N'diarylformamidine dithiocarbamate phosphine complexes; the effect of the metal center. Arab. J. Chem. 2020, 13, 6379-6394. [CrossRef]

290. Tetteh, S.; Dodoo, D.K.; Appiah-Opong, R.; Tuffour, I. Cytotoxicity, antioxidant and glutathione S -transferase inhibitory activity of palladium(II) chloride complexes bearing nucleobase ligands. Transit. Met. Chem. 2014, 39, 667-674. [CrossRef]

291. Corona-Bustamante, A.; Viveros-Paredes, J.M.; Flores-Parra, A.; Peraza-Campos, A.L.; Martínez-Martínez, F.J.; Sumaya-Martínez, M.T.; Ramos-Organillo, Á. Antioxidant Activity of Butyl- and Phenylstannoxanes Derivedfrom 2-, 3- and 4-Pyridinecarboxylic Acids. Molecules 2010, 15, 5445-5459. [CrossRef]

292. Chen, W.; Sun, S.; Cao, W.; Liang, Y.; Song, J. Antioxidant property of quercetin-Cr(III) complex: The role of Cr(III) ion. J. Mol. Struct. 2009, 918, 194-197. [CrossRef]

293. Fragoso, A.; Cao, R.; D'Souza, V.T. Influence of Positively-Charged Guests on the Superoxide Dismutase Mimetic Activity of Copper (II) $\beta$-Cyclodextrin Dithiocarbamates. J. Carbohydr. Chem. 1997, 16, 171-180. [CrossRef]

294. Martín, R.; Fragoso, A.; Cao, R. Complexation of bis (morpholyldithiocarbamato) copper (II), a superoxide scavenger, in $\beta$-cyclodextrins. Supramol. Chem. 2003, 15, 171-175. [CrossRef]

295. Cao, R.; Travieso, N.; Fragoso, A.; Villalonga, R.; Diaz, A.; Martinez, M.E.; Alpizar, J.; West, D.X. Determination of SOD-Like activity of Copper (II) complexes with $\alpha$-Amino acid dithiocarbamates. J. Inorg. Biochem. 1997, 66, 213-217. [CrossRef] 
296. Cao, R.; Pérez, L.G.; Moya, R.; Díaz, A. Interaction of Copper (II) Dithiocarbamates with Hydrogen Peroxide. Rev. Soc. Química México 2000, 44, 158-162.

297. Fragoso, A.; Cao, R.; Villalonga, R. Superoxide Dismutase Mimetic Activity of the Metal (II) Complexes of a Dithiocarbamate Derivative of $\beta$-Cyclodextrin1. Carbohydr. Chem. 1995, 14, 1379-1386. [CrossRef]

298. Díaz, A.M.; Villalonga, R.; Cao, R. Antioxidative properties of copper (II) complexes. J. Coord. Chem. 2009, 62, 100-107. [CrossRef]

299. Matsumoto, K.; Fujibayashi, Y.; Konishi, J.; Yokoyama, A. Radiolabeling and Biodistribution of ${ }^{62} \mathrm{Cu}$-Dithiocarbamate; An Application for the New ${ }^{62} \mathrm{Zn}^{62} \mathrm{Cu}$ Generator. Radioisotopes 1990, 39, 482-486. [CrossRef] [PubMed]

300. Southworth, R.; Torres Martin de Rosales, R.; Meszaros, L.K.; Ma, M.T.; Mullen, G.E.D.; Fruhwirth, G.; Young, J.D.; Imberti, C.; Bagunya-Torres, J.; Andreozzi, E.; et al. Opportunities and challenges for metal chemistry in molecular imaging: From gamma camera imaging to PET and multimodality imaging. Adv. Inorg. Chem. 2016, 68, 1-41.

301. Rowshanfarzad, P.; Sabet, M.; Reza Jalilian, A.; Kamalidehghan, M. An overview of copper radionuclides and production of $61 \mathrm{Cu}$ by proton irradiation of natZn at a medical cyclotron. Appl. Radiat. Isot. 2006, 64, 1563-1573. [CrossRef]

302. Dearling, J.L.J.; Mullen, G.E.D.; Lewis, J.S.; Welch, M.J.; Blower, P.J. Dithiocarbamate copper complexes as blood flow tracers. Label. Compd. Radiopharm. 1999, 42, 835.

303. Charoenphun, P.; Paul, R.; Weeks, A.; Berry, D.; Shaw, K.; Mullen, G.; Ballinger, J.; Blower, P. PET tracers for cell labelling with the complexes of copper 64 with lipophilic ligands. Eur. J. Nucl. Med. Mol. Imaging 2011, 38, S294.

304. Benyettou, F.; Lalatonne, Y.; Sainte-Catherine, O.; Monteil, M.; Motte, L. Superparamagnetic nanovector with anti-cancer properties: $\gamma \mathrm{Fe}_{2} \mathrm{O}_{3} @$ Zoledronate. Int. J. Pharm. 2009, 379, 324-327. [CrossRef]

305. Lalatonne, Y.; Paris, C.; Serfaty, J.M.; Weinmann, P.; Lecouvey, M.; Motte, L. Bis-phosphonates-ultra small superparamagnetic iron oxide nanoparticles: A platform towards diagnosis and therapy. Chem. Commun. 2008, 2553-2555. [CrossRef]

306. Ge, Y.; Xiao, D.; Li, Z.; Cui, X. Dithiocarbamate functionalized lignin for efficient removal of metallic ions and the usage of the metal-loaded bio-sorbents as potential free radical scavengers. J. Mater. Chem. A 2014, 2, 2136-2145. [CrossRef]

307. Xiang, B.; Fan, W.; Yi, X.; Wang, Z.; Gao, F.; Li, Y.; Gu, H. Dithiocarbamate-modified starch derivatives with high heavy metal adsorption performance. Carbohydr. Polym. 2016, 136, 30-37. [CrossRef] [PubMed]

308. Fu, F.; Xiong, Y.; Xie, B.; Chen, R. Adsorption of Acid Red 73 on copper dithiocarbamate precipitate-type solid wastes. Chemosphere 2007, 66, 1-7. [CrossRef] [PubMed]

309. Carella, A.; Borbone, F.; Centore, R. Research Progress on Photosensitizers for DSSC. Front. Chem. 2018, 6, 481. [CrossRef] [PubMed]

310. Singh, V.; Chauhan, R.; Gupta, A.N.; Kumar, V.; Drew, M.G.; Bahadur, L.; Singh, N. Photosensitizing activity of ferrocenyl bearing $\mathrm{Ni}(\mathrm{II})$ and $\mathrm{Cu}(\mathrm{II})$ dithiocarbamates in dye sensitized $\mathrm{TiO}_{2}$ solar cells. Dalton Trans. 2014, 43, 4752-4761. [CrossRef]

311. Yadav, R.; Waghadkar, Y.; Kociok-Köhn, G.; Kumar, A.; Rane, S.B.; Chauhan, R. Transition metal ferrocenyl dithiocarbamates functionalized dye-sensitized solar cells with hydroxy as an anchoring group. Opt. Mater. 2016, 62, 176-183. [CrossRef]

312. Ma, D.; Lu, X.; Shi, L.; Zhang, H.; Jiang, Y.; Liu, X. Domino Condensation/S-Arylation/Heterocyclization Reactions: CopperCatalyzed Three-Component Synthesis of 2-N-Substituted Benzothiazoles. Angew. Chem. 2011, 123, 1150-1153. [CrossRef]

313. Ashirbaev, S.S.; Levin, V.V.; Struchkova, M.I.; Dilman, A.D. Copper-Catalyzed Coupling of Acyl Chlorides with gem-Difluorinated Organozinc Reagents via Acyl Dithiocarbamates. J. Org. Chem. 2018, 83, 478-483. [CrossRef] [PubMed]

314. Gao, M.Y.; Xu, W.; Zhang, S.B.; Li, Y.S.; Dong, Z.B. Synthesis of Phenyl Dithiocarbamates Starting from Sodium Dialkyldithiocarbamates and Aryl Boronic Acids: A Copper Catalyzed S-Arylation. Eur. J. Org. Chem. 2018, 2018, 6693-6698. [CrossRef]

315. Dong, Z.-B.; Liu, X.; Bolm, C. Copper-catalyzed C ( $\left.\mathrm{sp}^{2}\right)-\mathrm{S}$ coupling reactions for the synthesis of aryl dithiocarbamates with thiuram disulfide reagents. Org. Lett. 2017, 19, 5916-5919. [CrossRef]

316. Zeng, M.T.; Xu, W.; Liu, X.; Chang, C.Z.; Zhu, H.; Dong, Z.B. Copper-Catalyzed S-Arylation of Tetraalkylthiuram Disulfides by Using Diaryliodonium Salts. Eur. J. Org. Chem. 2017, 2017, 6060-6066. [CrossRef]

317. Xu, W.; Gao, F.; Dong, Z.B. Copper-Catalyzed S-Arylation Starting from Arylboronic Acids and Tetraalkylthiuram Disulfide. Eur. J. Org. Chem. 2018, 2018, 821-828. [CrossRef]

318. Peng, K.; Zhu, H.; Liu, X.; Peng, H.Y.; Chen, J.Q.; Dong, Z.B. Chemoselective C-S/S-S Formation between Diaryl Disulfides and Tetraalkylthiuram Disulfides. Eur. J. Org. Chem. 2019, 2019, 7629-7634. [CrossRef]

319. Li, P.; Qiu, K.Y. Cu( $\left.\mathrm{S}_{2} \mathrm{CNEt}_{2}\right)$ Cl-Catalyzed Reverse Atom-Transfer Radical Polymerization of Vinyl Monomers. Macromol. Rapid Commun. 2002, 23, 1124-1129. [CrossRef]

320. Kwak, Y.; Nicolaÿ, R.; Matyjaszewski, K. A simple and efficient synthesis of RAFT chain transfer agents via atom transfer radical addition-fragmentation. Macromolecules 2009, 42, 3738-3742. [CrossRef]

321. Nishimura, M.; Kamigaito, M.; Sawamoto, M. Living radical polymerization of styrene with transition metal dithiocarbamate/AIBN systems: Halogen-free living processes. Polym. Prepr. 1999, 40, 470-471.

322. Pateman, A. Copper Catalysed Aziridination Reactions. Ph.D. Thesis, University College London, London, UK, 1999.

323. Pateman, A.; Cardell, D.C.; Hogarth, G. Copper Dithiocarbamate Complexes as Catalysts for Alkene Aziridination. University College London: London, UK, Unpublished work. 2003. 